GISELE PIRES DE MENDONÇA DANTAS

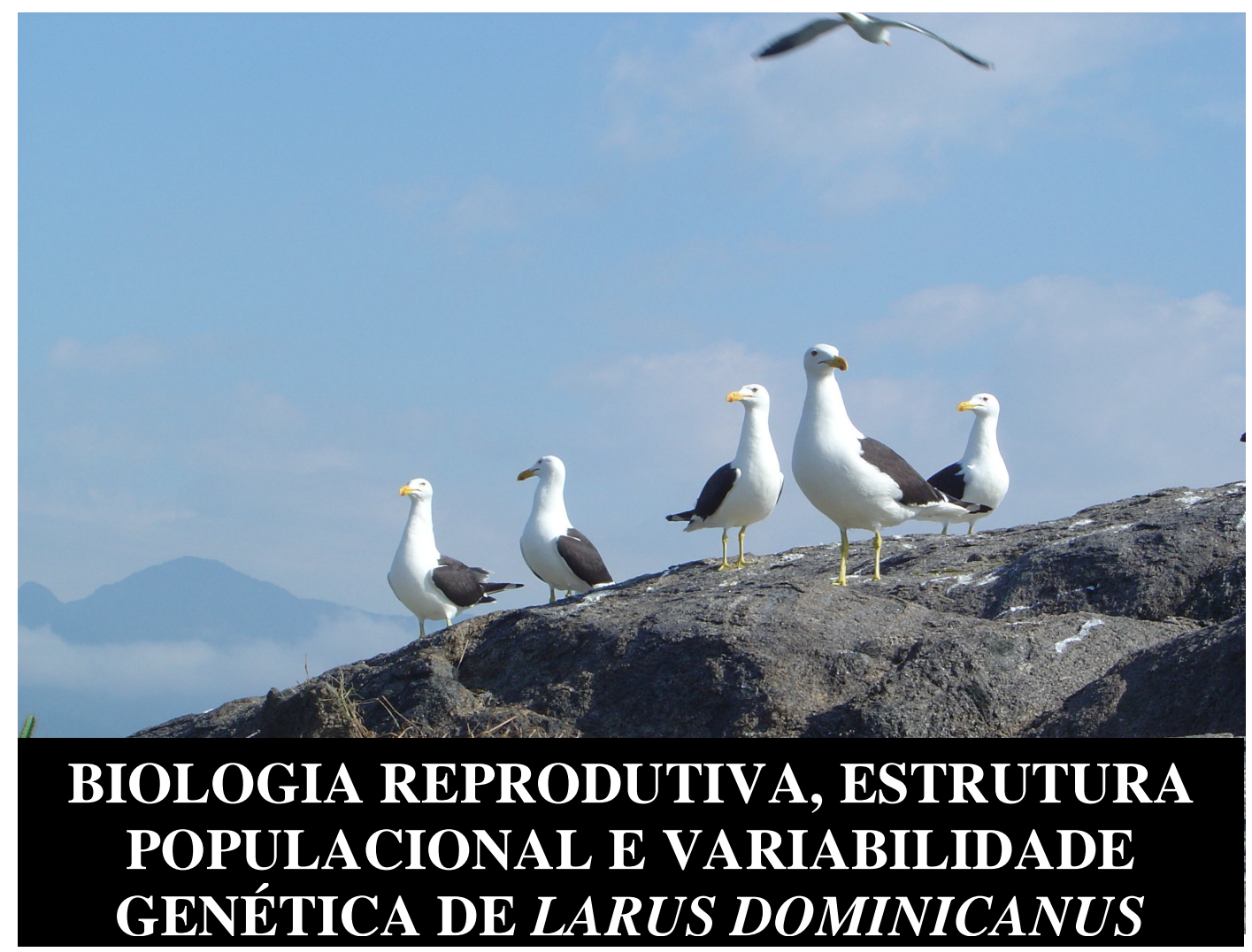

SÃO PAULO

2007 
GISELE PIRES DE MENDONÇA DANTAS

\section{BIOLOGIA REPRODUTIVA, ESTRUTURA POPULACIONAL E VARIABILIDADE GENÉTICA DE LARUS DOMINICANUS}

Tese apresentada ao Insituto de Biociências da Universidade de São Paulo, para a obtenção do título de Doutor em Ciências, na Área de Biologia/Genética Orientador : Prof. Dr. João Stenghel Morgante

São Paulo

2007 
Ficha Catalográfica

Dantas, Gisele Pires de Mendonça

Biologia Reprodutiva, estrutura populacional e variabilidade genética de Larus dominicanus.

$118 \mathrm{p}$

Tese (doutorado) - Instituto de Biociências da Universidade de São Paulo. Departamento de Genética e Biologia

Evolutiva

Palavras chaves: 1. Larus dominicanus 2.biologia evolutiva 3. razão sexual 4.variabilidade genética 5.estrutura populacional

Universidade de São Paulo.

Instituto de Biociências

Departamento de Genética e Biologia Evolutiva

Prof.(a) Dra. Maria Cristina Arias

Prof.(a) Dra. Maria Alice Masa

Prof.(a) Dra. Cristina Yumi Myiaki

Prof. Dr. Joaquim Olinto Branco

Prof. Dr. João Stenghel Morgante 
Dedico este trabalho aos meus pais, as minhas irmãs e aos novos membros da minha família o Pedrinho e Sheng 


\section{AGRADECIMENTOS}

Aqui termina quatro anos de trabalho, ou melhor se inicia outros muitos anos de pesquisa. Essa tese surgiu de um sonho de criança de trabalhar no mar, que no meio do caminho se encantou por ecologia de aves. E já mais tarde descobriu que a genética de populações voltada para evolução apresentava-se como uma grande ferramenta para a conservação da vida silvestre.

Ao longo dos quatro anos de doutorado não aprendi somente novas técnicas moleculares e de análises, mas aprendi a abrir a minha mente e ver a evolução como uma grande história, em que cada detalhe e cada espécie tem um significado especial. Onde todas as interações ecológicas existentes nos sistemas tem um sentido e uma ligação com a genética e os processos evolutivos que atuaram sobre as espécies ao longo de suas histórias.

É claro que para esse grande conhecimento e essa bagagem profissional e pessoal que levarei por toda a minha vida teve a participação de pessoas muito importantes. Entre essas pessoas uma das mais importantes foi o Professor João Stenghel Morgante que apesar de não me conhecer, aceitou me orientar, sendo um grande exemplo de vida e de pesquisador ao longo desses anos. Escutando quando algum problema surgia "uai, Chefe não era para ser assim?", mas sempre disposto a ajuda e apoiar mesmo quando eu estava distante em Portugal.

Não posso deixar de agradecer também a dois grandes exemplos de pesquisadores que conheci ao longo desses anos, Diogo Meyer e Ricardo Lopes que me ensinaram a questionar os meus dados além da simplicidade dos resultados.

As minhas grandes amigas, Nádia Morães, Juliana Ferreira e Larissa Rosa que se tornaram irmãs com a convivência em São Paulo. Aos Pais que eu conquistei, Neil e Eliana Ferreira, e sempre foram carinhosos e atenciosos comigo nesse período que aqui vivi.

A todos os colegas de laboratório que me apoiaram quando nada dava certo e me aplaudiram quando tudo funcionava, Rodrigo Ramalho, Rodrigo Francisco, Ana Carolina Paván, Caroline Aires, Márcia, Bia, Kelly e Felipe Martins. Especialmente agradeço a Fernanda Santos e ao André Rueda que foram estagiários desse projeto me ajudando muitas vezes no laboratório, e me ensinaram como orientar novas pessoas. A todas as pessoas que ajudaram no trabalho de campo: Renata Dantas, Juzinha, Daniel, Ándre, Jú Ferreira, Bia, Carol, Juliana Falcão, Catarina, Mariana, Izabel e Flávia. 
Agradeço a todos os amigos portugueses Bruno Simões, Joana, Teresa, Diana, Sofia Tavares, Sofia Mourão, Sofia Silva, Paula, Helena, Suzana, Miguel Carretero e a Dona Manuella que fizeram da minha estadia um momento feliz e inesquecível. Aos amigos do externos da USP que me ensinaram a otimizar o tempo e aumentar a produção, Fernanda Bonaffini e Rosemary.

A Renata Moretti e a Marcella Sobral pelo agradável convívio nesses últimos meses, podem acreditar....ter ido morar com vocês foi fundamental para conseguir terminar a minha tese.

Agradeço de forma especial ao Prof. Nuno Ferrand por me receber tão bem, abrir novas perspectivas para o projeto e por me acolher na sua família deixando que eu tivesse a oportunidade maravilhosa de conviver com o Pedrinho, ver a chegada do Miguel e conhecer a grande mulher e pesquisadora que é a Raquel Godinho.

A minha família que merece um capítulo especial, que foram as primeiras pessoas a acreditarem em mim, que sempre me incentivaram, que aprenderam a conviver com a distância e à saudade. Que nos momentos de tristezas me incentivavam à continuar e acreditar que Deus iria me ajudar. E essa família que agora cresceu com a chegada do Pedrinho (a tia estave ausente Pedrinho, mas vai ser doutora)

Ao amigo Luís Fábio pelas longas conversar e sugestões no trabalho e na vida pessoal. Ao Renato Caparroz pelas sugestões nessa fase final do trabalho, foi fundamental.

A Deus que sem dúvida alguma me ajudou ao longo do doutorado, permitindo que eu realizasse o projeto dos meus sonhos. E que apesar das dificuldades que encontramos pelo caminho permitiu que o resultado final fosse gratificante, pelo menos para mim.

As minhas grandes amigas, Adriana Medeiros, Carla Adriana e Melissa Ang e Lina que desde a graduação fomos construindo uma grande família que se ajuda em qualquer lugar do mundo.

Ao Sheng que fez dessa fase final da tese um momento mais leve. Você me ajudou muito, me incentivando, me admirando e me fazendo uma pessoa mais feliz. Pelo menos para te conhecer o meu doutorado vai servir....se ninguém mais ler essa tese nossos filhos lerão.

Aos colaboradores desse projeto que sempre ajudaram com as coletas e em tudo que eu precisasse Fausto Pires Campos, Joaquim Olinto Branco e Peter Ryan. 
A Rita, Luciana, Helenice e Deyse pela paciência em me ajudar em todos os momentos com as normas e protocolos da Universidade.

Agradeço a Fundação de Pesquisa do Estado de São Paulo (FAPESP) por conceder a bolsa de pesquisa pra o desenvolvimento desse trabalho (processo 03/015991) e por financiar os trabalhos e viagens do projeto do Laboratório de Biologia Evolutiva e Conservação de Vertebrados (processo 05/55438-4). À Coordenação de Aperfeiçoamento de pessoal de Nível Supeerior (CAPES) por conceder a bolsa de estágio no exterior, permitindo assim que os marcadores nucleares pudessem ser desenvolvidos (PDEE processo BEX3784/05-3). Ao Centro Nacional de Anilhamento de Aves (CEMAVE/IBAMA licença 1060) de trabalho para o desenvolvimento desse trabalho. A Estação Ecológica Juréia Itatins que ofereceu toda a logística necessária para o trabalho de campo na ilha de Guararitama. Ao Instituto Florestal de São Paulo, a Universidade do Vale do Itajaí e a equipe do professor Martin Sander (Unisinos) pelo apoio e logística nas coletas de campo. 


\section{ÍNDICE}

$\begin{array}{ll}\text { Abstract } & 10\end{array}$

Resumo 12

Introdução Geral 14

Capítulo I : Biologia reprodutiva de Larus dominicanus em Guararitama São Paulo

Introdução 18

Objetivo 20

Metodologia 20

Resultados $\quad 24$

Discussão 31

Capítulo II: Razão sexual de Larus dominicanus na costa brasileira 36

Introdução 36

$\begin{array}{ll}\text { Objetivo } & 38\end{array}$

Metodologia 38

Resultados $\quad 39$

Discussão 39

Capítulo III: Variabilidade Genética de Larus dominicanus na costa brasileira, utilizando DNA mitocondrial

Introdução 43

Objetivo 45

Metodologia 46

Resultados $\quad 48$

Discussão $\quad 50$

Capítulo IV: Comparação dos padrões filogeográficos reveldados por marcadores mitocondriais e nucleares em gaivotas

Introdução $\quad 54$

$\begin{array}{ll}\text { Objetivo } & 58\end{array}$

Metodologia $\quad 59$

Resultados $\quad 65$

Discussão $\quad 84$ 
Capítulo V : Estudos Populacionais de Larus dominicanus baseados em análises de locus nucleares ( $\beta$ - Fibrinogênio)

Introdução

90

Objetivo

92

Metodologia

92

Resultados

95

Discussão

99

Discussão Geral

103

Anexo I

105

Bibliografia

109 


\begin{abstract}
Larus dominicanus is a widely distributed species in the Southern Hemisphere, and it breeds on islands close to the continents. In the last few decades this species presented great population expansions, due to its generalist habits and its great competitive capacity. These populations expansions ended up leading to the displacement of other seabirds and marine mammals of the breeding sites. In this sense, studies that seek understanding the biology and evolution of L. dominucanus are fundamental to create management and conservation plans to the seabird assemblage on the Brazilian coast.

The primary aim of this study was to characterize the reproductive biology of Larus dominicanus, in order to determine the species reproductive success. In addition we evaluated the sex ratio of the populations throughout the Brazilian coast.

In order to accomplish this we studied the reproductive biology of the species in one breeding colony in São Paulo state. We observed that L. dominicanus presented high reproductive success with about $70 \%$ of the eggs hatching and $50 \%$ of the chicks surviving until the flight phase. The chicks present a fast growth and within 30 days were mature enough to fly, making them able to escape from the predators. We also observed that before the flight phase, during the egg phase and mainly the first 15 days of life, the eggs and the chicks were more susceptible to vulture attacks, the main predator of the species in São Paulo state. In this sense, with a 50\% rate survival and low predation rates after the flight phase, we can infer that the populations of $L$. dominicanus must be going through high increments per year.

The secondary sex ratio analyzed to all populations sampled through the Brazilian coast did not show deviation from the 1:1 proportion. This result indicated that the L. dominicanus populations are stable, a characteristic expected to be found in populations that breed in sites with good environmental conditions. In a case like this, the parents do not need to favor the gender that needs less energy to survive, what would lead to a deviation in the sex ratio.

In this scenario of high reproductive success and equal proportion of males and females in a widely distributed species, we expected to find high levels of genetic variability both among and in the populations. Nevertheless, our mitochondrial DNA (mtDNA) data revealed an opposite situation. We studied two mitochondrial genes (cytb, ATPase 8 and 6) and observed that throughout the whole Brazilian coast the
\end{abstract}


genetic diversity for the group was practically null. We found only one haplotype to the cytb and two haplotypes for the ATPase 8 and 6, these last two were different for one base pair. The low differentiation was maintained when we extended the sampling to the whole species' distribution, with samples from the Antarctic Peninsula and the Marion Islands, and sequences from the "Genbank" from Australia and Kerguelen Islands. We proposed two scenarios that could explain this extremely low variability, either the populations of L. dominicanus went through a severe demographic event, or through selection events.

In order to distinguish among this processes, we development 13 not linked nuclear markers, searching for a common pattern between the nuclear markers and the mtDNA genes. If the L. dominicanus populations had gone through demographic events, we expected to find the same expansion signal in the nuclear markers, once demographic events would be marked in the whole genome, both nuclear and mitochondrial. On the other hand, if the low genetic variability observed resulted from selective events, we expected to find variation in the nuclear DNA, and not to find an expansion signal. Our results showed exactly the last scenario, with high genetic diversity in all 13 nuclear not linked loci and no expansion signal. Even in more detailed analyses, with a higher number of individuals, the same pattern of neutrality, and not of population expansion, for the nuclear markers was found.

Therefore, we concluded that $L$. dominicanus is an extremely well adapted species for the new environmental conditions generated by antropic activities. The species showed great reproductive success and no deviation of the 1.1 sex ratio. The low genetic diversity observed in mitochondrial DNA compared with the high variability found in different nuclear loci, indicate that this species has gone through selective processes on the mitochondrial molecule. To the conservation point of view, the high genetic variability found in nuclear markers is in agreement with the wide distribution of the species. Apparently, this species do not present diversity levels low enough to generate worries regarding its maintenance. In addition, the low levels of diversity found on the mitochondrial DNA open new frontiers to understand how evolution has acted on marine organisms and what are the processes that lead to the diversification of this group. 


\section{RESUMO}

Larus dominicanus é uma espécie de ampla distribuição no Hemisfério Sul, que se reproduz em ilhas próximas ao continente. Esta espécie vem apresentando grande expansão populacional nas últimas décadas, devido ao seu hábito generalista e sua alta capacidade competitiva. O crescimento de sua população tem causado o deslocamento de diversas outras espécies de aves e mamíferos marinhos de seus sítios reprodutivos, devido ao constante impacto da predação e parasitismo. Todas essas características tem feito com que muitos pesquisadores considerem essa espécie como uma praga nos ambientes costeiros. Dessa forma, estudos que busquem compreender biologia e evolução são fundamentais para a criação de futuros planos de manejo e conservação da assembléia de aves marinhas na costa brasileira.

O presente estudo teve como objetivo caracterizar a biologia reprodutiva de $L$. dominicanus, buscando determinar seu sucesso reprodutivo. Bem como avaliar a razão sexual de suas populações ao longo da costa brasileira e estimar a variabilidade genética de suas populações no litoral do Brazil.

Para isto estudamos a biologia reprodutiva dessa espécie em uma colônia do estado de São Paulo. Observamos que L. dominicanus apresenta alto sucesso reprodutivo, cerca $70 \%$ dos ovos eclodiram e cerca de $50 \%$ dos filhotes sobreviveram até a fase de vôo. Os filhotes apresentaram um rápido crescimento, em 30 dias já estão grande o suficiente para voarem, o que os tornam aptos a escaparem os predadores. Os principais predadores dessa espécie no estado de São Paulo são os urubus, sendo a fase mais suceptível aos ataques foram a fase de ovo e os primeiros 15 dias de vida dos filhotes. Dessa forma, com uma sobrevivência de $50 \%$ dos filhotes e baixa predação após a fase de vôo, as as populações de L. dominicanus potencialmente podem apresentar grandes incrementos populacionais a cada ano.

A razão sexual secundária para todas as populações amostradas ao longo do litoral brasileiro não apresentaram desvio da proporção 1:1. Isso indica que as populações de L. dominicanus devem estar estáveis, o que é esperado de populações que se reproduzem em sítos com boas condições ambientais. De forma que, os pais não precisam favorecer o sexo que apresenta menor custo reprodutivo, levando ao desvio da razão sexual.

Dentro deste panorama de grande sucesso reprodutivo e proporção similar de machos e fêmeas em uma espécie de ampla distribuição geográfica, como $L$. dominicanus, esperávamos encontrar grande variabilidade genética dentro e entre suas 
populações. Entretanto, os resultados do presente estudo relativos a marcadores do DNA mitocondrial revelaram um cenário oposto. Estudando dois genes mitocondriais (citb e ATPase 8 e 6) foi observado que ao longo de toda a costa brasileira a diversidade genética desse grupo foi praticamente nula. Encontramos um único haplótipo para o citocromo b e dois haplótipos para a ATPase 8 e 6 que se diferenciam por um único par de base. Essa baixa diferenciação se manteve quando ampliamos a amostragem ao longo da distribuição dessa espécie, com amostras da Península Antartica, ilhas Marion e de sequências disponíveis no "Genbank" provenimentes da Austrália e Ilhas Kerguelen. Para justificar essa baixa diversidade genética levantamos duas possíveis explicações, as populações de L. dominicanus teriam passado por um severo evento demográfico ou por eventos de seleção.

Para distinguir entre esses dois cenários desenvolvemos 13 marcadores nucleares não ligados, buscando encontrar um padrão caso as populações de L. dominicanus tivessem passado por eventos demográficos. Eventos demográficos marcam o genoma da espécie como um todo (DNA mitocondrial e nuclear), por outro lado eventos seletivos marcam somente o loccus sob seleção e gene ligados a estes. Dessa forma, se a redução da variabilidade genética de Larus dominicanus for resultado de eventos seletivos é esperado que marcadores DNA nuclear apresentem variação, mas não apresentem sinal de expansão populacional. Nos 13 loci nucleares analisados no presente estudo foi observado grande diversidade genética e nenhum sinal de expansão populacional.

Assim, concluímos que L. dominicanus é uma espécie adaptada às novas condições ambientais criadas pelas atividades antrópicas. Essa espécie apresenta grande suceso reprodutivo e nenhum desvio da razão sexual. A baixa diversidade genética observada no DNA mitocondrial comparada com a alta variabilidade encontrada em diferente loci nucleares, parece indicar que essa espécie tenha passado por um evento de seleção na molécula mitocodrial. Do ponto de vista da conservação a alta variabilidade genética encontrada no nuclear é condizente com a ampla distribuição da espécie. Aparentemente essa espécie não demonstra ter o baixo nível de diversidade a ponto de ser preocupante para a manutenção da espécie. Por outro lado, a baixa diversidade encontrada no DNA mitocondrial abre uma importante expectativa para se compreender como a evolução tem atuado nos organismos marinhos e quais os processos que tem levado à diversificacação desse grupo. 


\section{INTRODUÇÃO GERAL}

Biodiversidade é um termo amplo, que significa a diversidade de vida na terra. Entretanto, esse termo refere-se a toda a amplitude de diversidade biológica: a diversidade de ecossistemas, a diversidade de espécies e a diversidade genética. A diversidade da vida começa com as diferenças genéticas entre populações, espécies e os processos evolutivos que atuam sobre elas (HUNTER, 1996). Comunidades biológicas que levaram milhões de anos para se desenvolverem vêm sendo devastadas pelo homem em diferentes regiões da terra (PRIMACK \& RODRIGUES, 2001).

Os impactos observados na natureza, como o desmatamento de áreas naturais, a ocupação da costa, a caça excessiva de algumas espécies e a introdução de espécies exóticas são decorrentes do crescimento da população humana e suas atividades. O grande desafio atual é conciliar os interesses humanos com a conservação da natureza. A biologia da conservação surgiu como resposta a essa crise, como uma atividade multidisciplinar que tem como objetivos principais: investigar os efeitos humanos sobre os demais seres vivos, comunidades biológicas e os ecossistemas; desenvolver práticas para prevenir a degradação ambiental e extinção das espécies, a restauração de ecossistemas e a reintrodução de populações, restabelecendo relações sustentáveis entre as comunidades humanas e ecossistemas (ROZZI et al., 1998).

A biologia da conservação busca integrar várias áreas, entre estas a ecologia e a genética. Estudos de ecologia e genética de populações são essenciais para estabelecer unidades de conservação, de forma que toda a diversidade da espécie ou do grupo seja preservada (MORITZ, 2002). Para entendermos um ecossistema é necessário conhecermos o comportamento das espécies, a dieta, a dinâmica das populações e as interações em diferentes níveis tróficos. Por outro lado, estudos genéticos permitem ter 
acesso a história evolutiva de uma espécie ou grupo, onde podemos encontrar padrões para explicar a distribuição geográfica observada atualmente.

Muitas espécies de aves exploram o mar para sobreviver e muitos fatores podem prejudicar a sobrevivência desses organismos. A poluição do mar por resíduos orgânicos, a destruição de sítios de nidificação, a ocorrência de queimadas frequentes em ilhas, a pesca excessiva de algumas espécies que são recursos alimentares para as aves, a retirada de ovos nas colônias como forma de exploração econômica, a introdução de animais em ilhas e o turismo descontrolado são algumas das pressões antrópicas em que os ambientes marinhos estão sujeitos (ROSÁRIO, 1996).

Registros de extinção desde de 1600 revelaram que a maioria das extinções que ocorreram são com espécies insulares, embora estas representem a minoria do total de espécies de todos os grupos (FRANKHAM et al., 2002). Somente $20 \%$ do total de espécies de aves vivem em ilhas, mas $80 \%$ das aves que estão ameaçadas de extinção são espécies insulares (FRANKHAM et al., 2002). O que torna grupos insulares extremamente importantes para o estudo de diversidade biológica com o propósito de entender os processos evolutivos que atuam sobre esses grupos.

As gaivotas fazem parte da família Laridae, ordem Charadriiformes, sendo o género Larus um dos mais abundantes entre as aves marinhas, com cerca de 45 espécies, das quais 9 ocorrem na América do Sul e 3 são residentes no litoral brasileiro (HARRISON, 1985). Geralmente este grupo forma colônia em ilhas próximas do continente (VIDAL et al., 2001). As colônias variam de poucos a milhares pares reprodutivos e a postura apresenta de 1 a 3 ovos por ninho (GILL, 1994). O tempo de incubação é variável de acordo com a espécie de Laridae, mas fica em torno de 20 a 30 dias. 
Larus dominicanus (gaivotão) é uma espécie de ampla distribuição no Hemisfério Sul, que possui duas subespécies: Larus dominicanus vetula ocorre na África e Larus dominicanus dominicanus que ocorre na Nova Zelândia, Austrália, América do Sul e Península Antártica (BERTELlOTI \& YORIO, 1999). No Brasil, essa é uma espécie residente, que ocorre do Rio de Janeiro ao Rio Grande do Sul (SICK, 1997).

Os gaivotões têm preocupado diversos pesquisadores e conservacionistas, devido à grande expansão populacional que têm apresentado nas últimas décadas. Na Argentina sua população aumentou de 3200 para 6500 pares reprodutivos no período de 1982 a 1995 (QUINTANA \& YORIO, 1998). Essa espécie apresenta o hábito alimentar generalista, se alimentando de uma ampla diversidade de presas, inclusive diversos resíduos de atividades humanas. Os gaivotões já foram observados se alimentando de resíduos produzidos por embarcações pesqueiras, em lixões e casas de abate de animais (YORIO et al., 1998). Em alguns casos, o hábito de se alimentar em depósitos de lixo e esgotos pode resultar na infecção das gaivotas por patógenos que são prejudiciais ao homem (YORIO et al., 1998). Resultados preliminares têm mostrado que Larus dominicanus pode ser vetor de enterobactérias patogênicas para humanos (GIACCARDI 1997).

Essa espécie tem demonstrado grande capacidade competitiva ao colonizar novos habitats, deslocando espécies menores e de distribuição mais restritas. Os gaivotões já foram observados predando ovos e/ou filhotes de Spheniscus magellanicus (Pinguim de Magalhães), Phalacrocorax atriceps (Biguá Imperador), Sterna máxima (Trinta-réis Real), Sterna eurygnattha (Trinta-reis de Bico Amarelo) e Macronectes giganteus (Petrel Gigante) (YORIO et al. 1998). ROWTREE et al. (1998) observaram L dominicanus se alimentando de pedaços de pele e carne de Baleia Franca austral 
(Eubalaena australis) enquanto essa emerge para respirar (Figura 1) na Península Valdez, Argentina.

Apesar de sua grande distribuição e do grande impacto que essa espécie tem causado em outras aves marinhas e mamíferos, pouco se sabe sobre sua biologia reprodutiva (YORIO et al., 1995, BERTELLOTI \& YORIO, 1999) e variabilidade genética (DANTAS et al., 2006). Dessa forma, estudos que procuram elucidar aspectos ecológicos e genéticos dessa espécie se tornam extremamente necessários para a conservação da biodiversidade da assembleia de aves marinhas da costa brasileira, e para a criação de futuros efetivos planos de manejo para os Gaivotões.

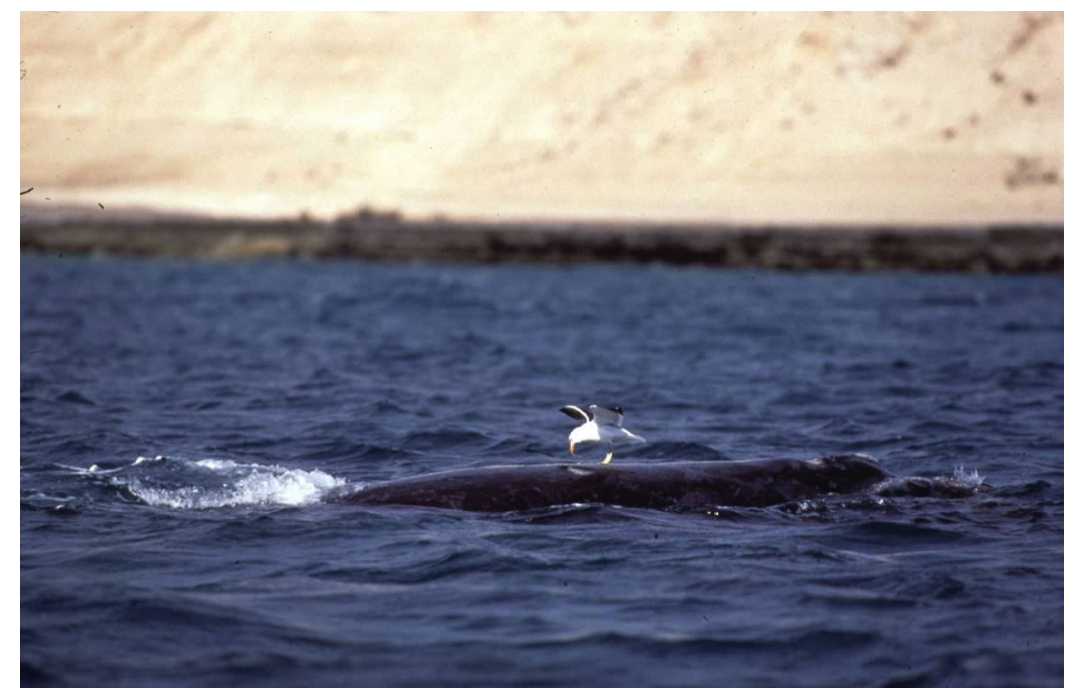

Figura 1.: Larus dominicanus atacando Eubalaena asutralis na Península Valdez Argentina. Foto de Ian Kerr.

Dentro desse contexto, a presente tese procurou investigar três pontos principais, relacionados às características populacionais de Larus dominicanus. 1. Estudar a Biologia Reprodutiva dessa espécie no litoral Paulista. 2. Verificar se a razão sexual dessa espécie desvia a proporção de 1:1 em diferentes localidades ao longo do litoral brasileiro. 3. Estudar a distribuição da variabilidade genética dessa espécie no litoral brasileiro e ilhas subantárticas. 


\section{CAPITULO I}

\section{BIOLOGIA REPRODUTIVA DE LARUS DOMINICANUS NA ILHA DE GUARARITAMA, SÃO PAULO}

\section{INTRODUÇÃO}

A biologia reprodutiva é o ramo da ciência que busca compreender aspectos relacionados à reprodução de uma espécie, entre eles o tamanho da ninhada, a energia gasta na reprodução e a taxa da sobrevivência. Estudos de biologia reprodutiva são a base para o conhecimento da dinâmica de populações.

Mudanças no tamanho das populações são resultado de três processos, da reprodução, da sobrevivência e da migração (DOHERTY \& GRUBB, 2002). O sucesso reprodutivo está associado à muitos fatores ecológicos (interações intra e interespecíficas, disponibilidade de alimentos, escolha do sítio reprodutivo) e fatores ambientais (umidade, temperatura, vento) (PAYNTER, 1949; BORBOROGLU \& YORIO, 2004). Dessa forma, estudos que busquem compreender as taxas de sobrevivência e mortalidade nas populações ao longo do tempo podem ser eficientes ferramentas para monitorar às mudanças ambientais. Além disso, estimativas de sucesso reprodutivo são essenciais para avaliar o crescimento de uma determinada população e para a criação de efetivos programas de manejo e proteção de espécies.

As gaivotas da família Laridae (Aves: Charadriiformes) geralmente formam colônias em ilhas próximas do continente (VIDAL et al., 2001). Colônias de gaivotas vêm sendo extensivamente estudadas do ponto de vista de seleção de habitat e da dieta (RODWAY \& REGHER, 1999; ORO \& PRADEL, 2000; VIDAL et al., 2001). Entretanto, poucos estudos têm sido desenvolvidos com espécies de gaivotas na 
América do Sul (YORIO et al., 1995; BERTELLOTTI \& YORIO, 1999). Larus dominicanus é uma espécie de ampla distribuição no Hemisfério Sul e residente na costa Brasileira (SICK, 1997), porém o conhecimento da sua biologia de nidificação é escasso. No Brasil sabe-se somente que L. dominicanus nidifica no inverno em ilhas próximas da costa (RÓSARIO, 1996; SICK, 1997).

As gaivotas utilizam uma ampla variedade de sítios reprodutivos para reprodução, alguns em áreas abertas e outros em áreas cobertas por vegetação (GUICKING et al., 2001). Estudos realizados com L. dominicanus na Península Valdez, Argentina, têm mostrado que esta espécie nidifica em uma ampla variedade de habitats, mas que preferem áreas com cobertura vegetal (BORBOROGLU \& YORIO, 2004). A vegetação ajuda a camuflar os ninhos, protegendo os filhotes contra a predação e o stress causado pelo calor excessivo. A escolha do local de nidificação é essencial para o sucesso reprodutivo de muitas espécies, devendo esse prover proteção contra predadores e condições extremas do tempo (GUICKING et al., 2001; GOOD-THOMAS, 2002; BORBOROGLU \& YORIO, 2004). Uma vez que, a predação, a inanição e o stress por calor excessivo são as principais causas de mortalidade de filhotes (PAYNTER, 1949).

Alguns autores acreditam que a formação de colônias, para aves marinhas, tem mostrado ser importante para evitar a predação, sendo esta mais baixa em colônias com densidades altas (ANDERSON \& HODUM, 1993; ORO, 1996). Outro comportamento que algumas espécies de gaivotas apresentam é a formação de grandes grupos de filhotes (crechés). Esses grupos movem-se como unidade e são cercados por indivíduos adultos. Acredita-se que essa agregação possa reduzir a predação, além de reduzir os custos dos pais com o cuidado da prole (YORIO et al., 1996). Como muitas dessas espécies não apresentam dimorfismo sexual é difícil estabelecer padrões de comportamento reprodutivo e com o cuidado da prole. Entretanto, acredita-se que 
ambos os sexos apresentam cuidado parental tendo parte na incubação, alimentação dos filhotes, defesa dos ninhos e da prole (YORIO et al., 1996).

Larus dominicanus é uma espécie extremamente agressiva, de ampla distribuição, que vem apresentando grande expansão populacional nas últimas décadas. Apesar de sua ampla distribuição e do grande impacto que essa espécie vem causando em outras aves marinhas e mamíferos, pouco se sabe sobre sua biologia reprodutiva (YORIO et al., 1995; BERTELLOTI \& YORIO, 1999). O conhecimento das taxas de sobrevivência e mortalidade são importantes estimativas de recrutamento populacional. Assim, trabalhos que busquem avaliar a biologia reprodutiva dessa espécie são fundamentais para que possamos no futuro criar um plano de manejo visando a conservação dessa e de outras espécies de aves marinhas na costa brasileira.

\section{OBJETIVOS}

Este trabalho visou elucidar características da biologia reprodutiva de Larus dominicanus na ilha de Guararitma, sul do litoral de São Paulo, buscando determinar:

o tamanho da ninhada de L dominicanus no litoral paulista

o período de incubação

a taxa de sobrevivência e de predação de ovos e filhotes

os possíveis predadores dessa espécie no litoral sul de São Paulo

o tempo necessário para que os filhotes deixem os ninhos

a taxa de crescimento dos filhotes

\section{MATERIAIS E MÉTODOS}

Área de trabalho 
Este trabalho foi realizado na ilha de Guararitama $\left(24^{\circ} 23^{\prime} \mathrm{S}, 46^{\circ} 59^{\top} \mathrm{W}\right)$, no litoral sul do Estado de São Paulo (Figura 2). Esta ilha se encontra a 1,9 $\mathrm{Km}$ de distância da costa, na barra do rio Guaraú, em frente a Estação Ecológica Juréia-Itatins. É uma ilha rochosa, com vegetação herbáceo-arbustiva esparsa e área de 1.2 hectares. Guararitama apresenta uma grande colônia de Larus dominicanus com cerca de 100 pares reprodutivos (CAMPOS et al. 2004). Acredita-se que a presença das gaivotas nessa ilha tenha sido a razão para a escolha do seu nome, "Guararitama" que significa em Tupi-Guarani "pedra rodeada de aves".

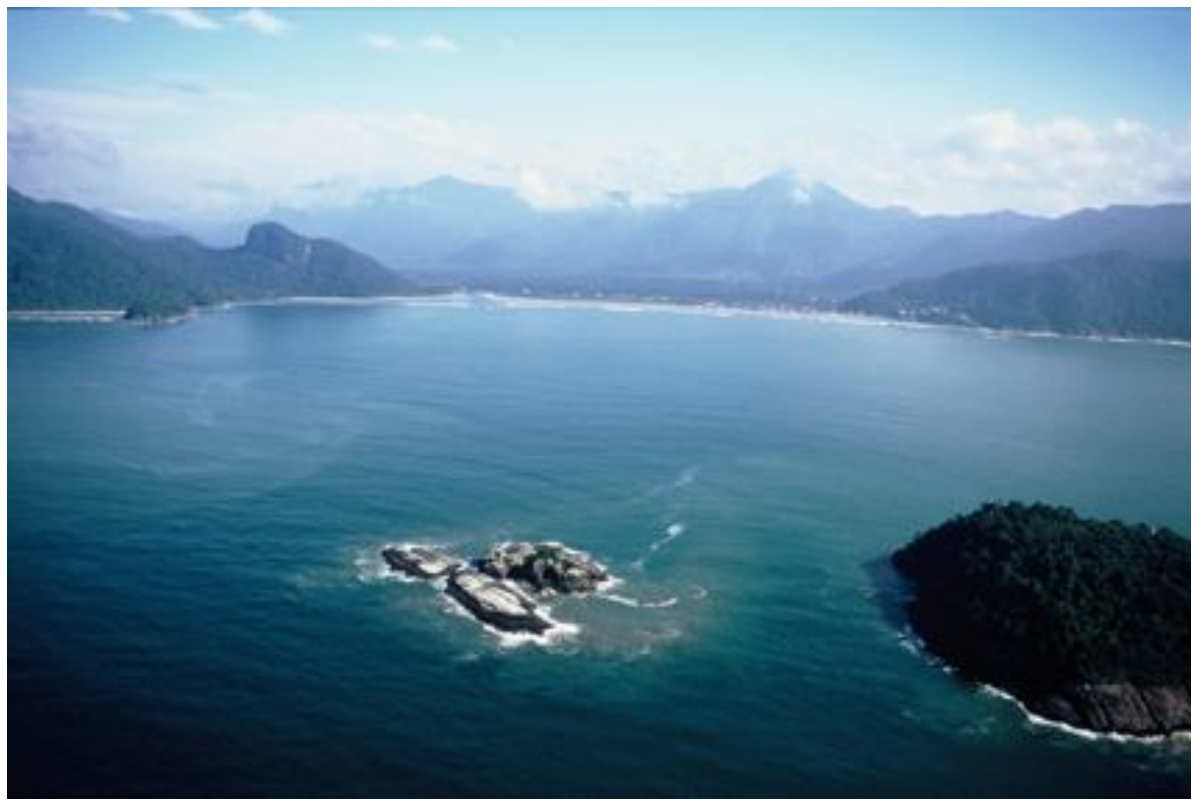

Figura 2.: Ilha de Guararitama, São Paulo, Brasil (vista aérea - foto de Fausto Campos)

\section{Monitoramento dos ninhos}

Durante as estações reprodutivas de 2004 e 2005 foram realizadas visitas regulares de 5-7 dias, entre os meses de junho a novembro, de acordo com as condições climáticas de forma que possibilitasse o acesso a ilha. Todos os ninhos, ovos e filhotes foram marcados e acompanhados em cada visita. Assim que os ovos eram detectados, 
eles foram marcados com caneta a prova d’água de ponta macia. Nesse momento foram registrados o comprimento e a largura dos ovos com auxílio de um paquímetro (precisão de $0,1 \mathrm{~mm}$ ) e em todas as visitas os ovos foram pesados com balança tipo pêsola (precisão de 1,0 g). Os ninhegos foram capturados com as mãos ou com auxílio de um puçá, anilhados com anilhas metálicas cedidas pelo CEMAVE/IBAMA (Licença 1060). De cada ninhego foram registrados o peso, com auxílio de uma balança tipo pêsola (precisão de 1,0 e de 10,0g) e as medidas de comprimento de asa direita, do metatarso direito, bico com um paquímetro (precisão de $0.1 \mathrm{~mm}$ ).

\section{Estimativas e padronizações}

Foram calculadas as porcentagens de predação, de abandono e de sucesso de ninhos, bem como a média e o desvio padrão dos parâmetros dos ovos (volume e massa) e dos filhotes (comprimento da asa, do metatarso direito, do bico e da massa corporal). Adicionalmente foram obtidas informações sobre o período de incubação e alimentação dos filhotes.

Foram considerados ninhos bem sucedidos aqueles em que pelo menos um filhote deixou o ninho. O ninho foi considerado predado quando: (a) encontrado vazio antes do período em que os filhotes deveriam deixá-lo, (b) com a casca quebrada no seu interior ou nas proximidades sem sinal de eclosão (fezes dos filhotes), (c) se estivesse destruído, (d) se os filhotes fossem encontrados mortos com sinais de agressão, como feridas e bicadas. Os ninhos foram considerados abandonados se os ovos permaneceram no ninho sem eclodir após 40 dias ou se os filhotes fossem encontrados mortos e sem sinal de agressão. Foi considerado como o tempo de permanência do filhote no ninho todo o período da eclosão até o filhote deixar o ninho para voar.

Os volumes dos ovos foram calculados por meio da equação do HOYT (1979):

$$
\text { Volume }=0,51 \mathrm{X}(\text { comprimento })(\text { largura })^{2}
$$


Foi calculado o número de fêmeas por estação reprodutiva (bx); a fecundidade (Fx); e a fertilidade (mx) (PIANKA, 1999).

bx=o número de fêmeas foi considerado equivalente ao número de ninhos

Fx= número de ovos postos/ número de indivíduos (fêmeas)

mx=número de ovos que sobrevivem / número de indivíduos (fêmeas)

As diferenças das taxas de predação e do sucesso de eclosão entre os períodos reprodutivos e entre os picos de postura de ovos dentro de cada período reprodutivo foram testados através do teste qui-quadrado. O sucesso dos ninhos com diferentes números de ovos foi testada através do teste de Mann Whitney (SAMPAIO, 2002). A diferença do volume dos ovos entre as estações reprodutivas e entre os picos de posturas dentro da mesma estação foram testados pelo "teste t". Nessas análises todos os ovos foram considerados, não diferenciando o primeiro, segundo e terceiro ovo. A metodologia utilizada nesse trabalho, como o intervalo entre as visitas, impossibilitou o registro da sequência de postura de ovos nos ninhos. Entretanto, como ao longo do período reprodutivo a postura de ovos apresentou picos bem distintos, todos os conjuntos testado pelo teste $t$ continham tanto ovos de primeira, segunda e terceita postura. Dessa forma, os resultados obtidos nos testes comparativos acima não foram prejudicados pela metodologia adotada.

O crescimento dos filhotes foi obtido através da equação logística entre o peso dos filhotes e o tempo de vida (dias) (Ricklefs, 1967). Para calcular a taxa de crescimento dos filhotes foram considerados somente os filhotes que foram capturados mais de uma vez ao longo da época reprodutiva, sendo que uma destas datas no dia da eclosão $(n=17)$. Através da equação de crescimento dos filhotes calculamos através do peso a idade dos ninhegos capturados somente uma vez ao longo das estações 
reprodutivas. Através dessa estimativa de idade dos filhotes foi obtida a relação entre a idade e o comprimento do bico, do metatarso direito e da asa.

\section{RESULTADOS}

A estação reprodutiva de Larus dominicanus no litoral de São Paulo começou em meados de Junho e foi até o início de Novembro. Durante a estação reprodutiva de 2004 foram marcados 195 ovos e 93 ninhos e na estação reprodutiva de 2005 foram marcados 172 ovos e 97 ninhos. A postura dos ovos foi assincrônica ao longo da estação reprodutiva. Em 2004 foi observado dois picos de postura de ovos, o primeiro em julho e o segundo em setembro e em 2005 foram observados um pico em agosto e outro em outubro (Figura 3).

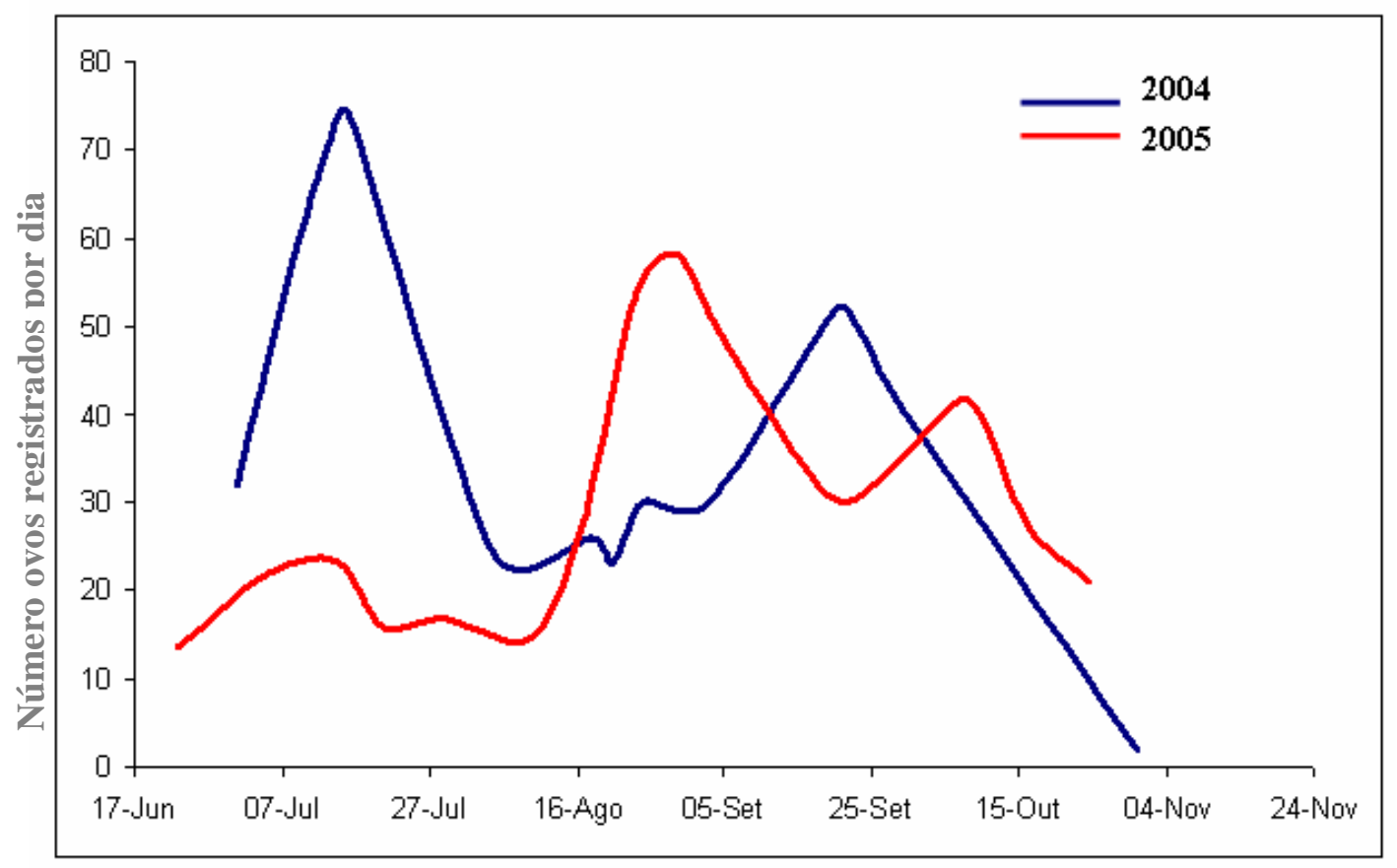

Estação reprodutiva

Figura 3.: Número de ovos postos por dia ao longo das estações reprodutivas de 2004 e 2005 na Ilha de Guararitama, São Paulo. 
Dos 195 ovos postos na estação reprodutiva de 2004, 93 ovos foram postos no pico de julho e 102 no pico de setembro. Os ovos do início da estação reprodutiva de 2004 apresentaram maior sucesso de eclosão em relação aos ovos do período tardio $\left(\mathrm{x}^{2}=10.09 \mathrm{p}=0.006\right)$ (Tabela II). Já na estação reprodutiva de 2005 dos 173 ovos postos, 39 foram postos no início da estação antes do primeiro pico de postura, 53 no pico de agosto e 40 no pico de setembro. O primeiro pico de ovos de 2005 também apresentou maior sucesso de eclosão em relação ao segundo pico $\left(\mathrm{x}^{2}=7.11 \mathrm{p}=0.03\right)$ (Tabela II). Entretanto, quando foi comparado o sucesso de ninhos entre os dois picos de postura tanto em 2004 como em 2005, não houve diferença significativa entre os períodos (2004 $\mathrm{x}^{2}=1.43 \mathrm{p}=0.48 ; 2005 \mathrm{x}^{2}=0.05 \mathrm{p}=0.94$ ) (Tabela III). Entretanto, a comparação do sucesso de ninhos e ovos entre os anos 2004 e 2005 mostraram diferenças significativas (teste $\mathrm{x}^{2}=18.13 \mathrm{p}<0.01$ ), sendo o sucesso maior no ano de 2004 .

A diferença entre o tamanho médio da ninhada entre os anos não foi significativa (test "t" $=1,77, \mathrm{p}=0,07)$ (Tabela I). Geralmente, as gaivotas fizeram posturas de 1 a 3 ovos e também não houve significativa diferença entre o número de ninhos com 1, 2 ou 3 ovos entre os anos (test " $\mathrm{t} "=0,22, \mathrm{p}=0,84$ ). $\mathrm{O}$ ano de 2005 apresentou maior número de fêmeas, entretanto a fecundidade e a fertilidade foi maior no ano de 2004 (Tabela I).

Tabela I: Dados comparativos de caracteristicas reprodutivas de Larus dominicanus na Ilha de Guararitama, São Paulo, nas estações reprodutivas de 2004 e 2005.

\begin{tabular}{llllll}
\hline & Tamanho Ninhada & Tempo de eclosão & bx & Fx & Mx \\
\hline 2004 & $2,09 \pm 0,64$ & $24,12 \pm 4,48$ & 93 & 2,096 & 1,387 \\
\hline 2005 & $1,93 \pm 0,59$ & $22,78 \pm 3,27$ & 97 & 1,773 & 0,422 \\
\hline
\end{tabular}

número de fêmeas por estação reprodutiva (bx), fecundidade (Fx), fertilidade (mx).

A estimativa do volume de ovos evidenciaram uma significativa diferença entre os dois picos de postura em ambas as estações reprodutivas $(2004 \mathrm{t}=4,34 \mathrm{p}<0,001$; 
$2005 \mathrm{t}=2,24 \mathrm{p}=0,026)$. Em 2004, o volume médio dos ovos no primero pico foi 88,11 $\pm 8,28 \mathrm{~cm}^{3}$ ( $\mathrm{n}=85$ )e no segundo pico de $83,80 \pm 12,68 \mathrm{~cm}^{3}(\mathrm{n}=110)$. Já em 2005 , o volume médio dos ovos no início da estação foi de $87,01 \pm 8,12 \mathrm{~cm}^{3}(\mathrm{n}=52)$, no primeiro pico foi $87,18 \pm 9,01 \mathrm{~cm}^{3}\left(\mathrm{n}=75\right.$ ) e no segundo pico $82,43 \pm 12,97 \mathrm{~cm}^{3}(\mathrm{n}=45$ ) (Figura 4). Do mesmo modo que entre os anos de 2004 e 2005 também houve diferença significativa entre as médias dos volumes dos ovos ("teste t" t=1,95, $\mathrm{p}=0,046$ ), sendo a média de 86,32 $\pm 10,37 \mathrm{~cm}^{3}$ em 2004 e 84,13 $\pm 10,75 \mathrm{~cm}^{3}$ em 2005 (Fig. 4)

Em ambos os anos, o primeiro pico da estação reprodutiva apresentou maior sucesso de eclosão em relação ao segundo pico $\left(2004 \chi^{2}=10,09 \mathrm{p}=0,006 ; 2005 \chi^{2}=7,11\right.$ $\mathrm{p}=0,03$ ). Comparando as estações reprodutivas de 2004 e 2005, o ano de 2004 apresentou maior sucesso de eclosão em relação ao ano de 2005 (teste $\chi^{2}=18,13 \mathrm{p}<0,01$ ) (Tabelas I e II). A predação foi a principal causa de perda de ovos (25,64\% em 2004 e $69,94 \%$ em 2005) e morte de filhotes (34,88\%em 2004 e 5,76\% em 2005). Os principais predadores de $L$ dominicanus em Guararitama foram os urubus para a fase de ovos e indivíduos adultos da própria espécie para os filhotes. 


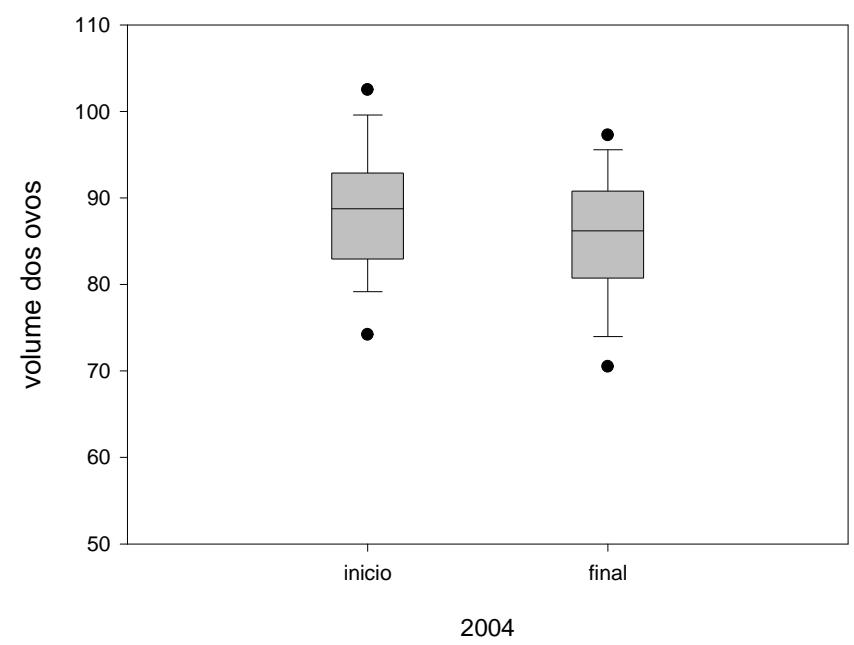

a

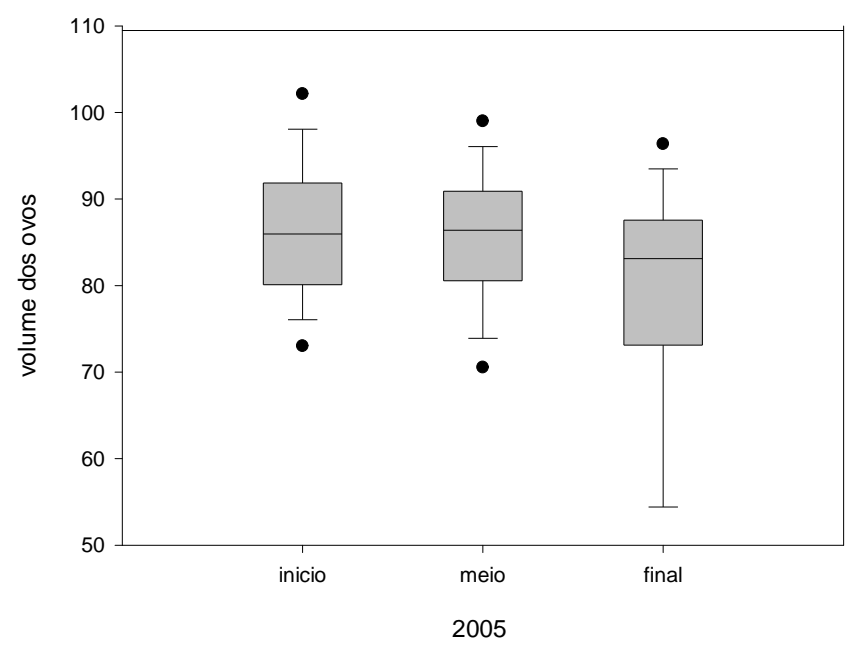

b

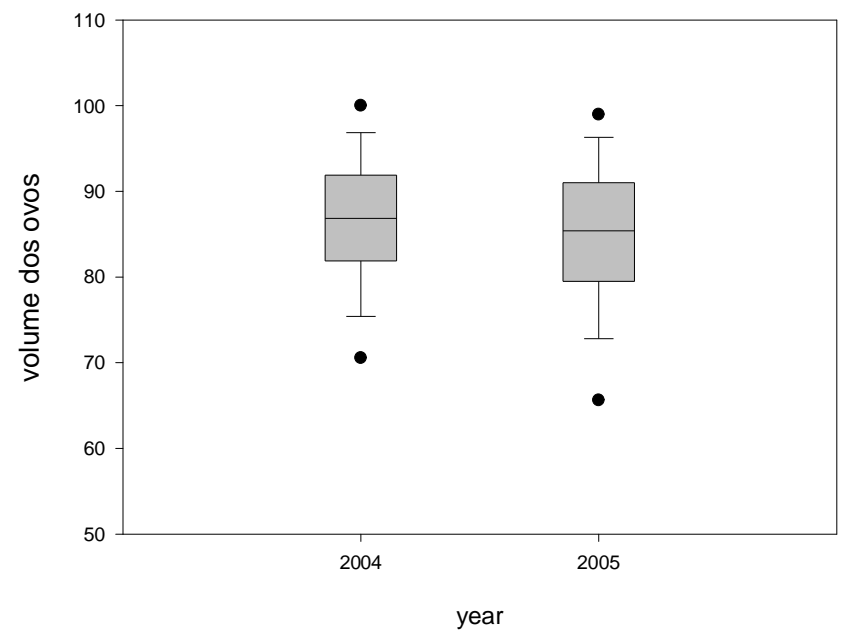

Figura 4.: Diferença entre os volumes dos ovos $\left(\mathrm{mm}^{3}\right)$ de L. dominicanus ao longo das estações reprodutivas de 2004 (a), de 2005 (b) e entre os anos (c), na ilha de Guararitama, São Paulo. 
Tabela II: Frequência de ovos com sucesso, predados e abandonados durante as estações reprodutivas de Larus dominicanus em 2004 e 2005, na Ilha de Guararitama, SP.

\begin{tabular}{l|l|l|l|l|l}
\hline & & Ovos sucesso & Ovos predados & $\begin{array}{l}\text { Ovos } \\
\text { abandonados }\end{array}$ & Total \\
\hline 2004 & Inicio da estação & $65(69,89 \%)$ & $16(17,20 \%)$ & $12(12,9 \%)$ & 93 \\
& Final da estação & $64(62,74 \%)$ & $34(33,33 \%)$ & $4(3,92 \%)$ & 102 \\
& Total & $129(66,15 \%)$ & $50(25,64 \%)$ & $16(8,20 \%)$ & 195 \\
\hline 2005 & Inicio da estação & $14(35,90 \%)$ & $23(58,97 \%)$ & $2(5,13 \%)$ & 39 \\
& Primeiro pico & $18(20,00 \%)$ & $69(76,67 \%)$ & $3(3,33 \%)$ & 90 \\
& Segundo pico & $9(20,45 \%)$ & $29(65,91 \%)$ & $6(13,64 \%)$ & 44 \\
\hline & Total & $41(23,70 \%)$ & $121(69,94 \%)$ & $11(6,36 \%)$ & 173 \\
\hline
\end{tabular}

Tabela III.: Frequência de ninhos com sucesso, predados e abandonados durante os períodos reprodutivos de Larus dominicanus em 2004 e 2005, na Ilha de Guararitama, SP.

\begin{tabular}{l|l|l|l|l|l}
\hline & & Ninhos sucesso & Ninhos predados & $\begin{array}{l}\text { Ninhos } \\
\text { abandonados }\end{array}$ & Total \\
\hline 2004 & Inicio da estação & $28(76,31 \%)$ & $7(18,42 \%)$ & $2(5,26 \%)$ & 38 \\
& Final da estação & $37(67,27 \%)$ & $16(29,09 \%)$ & $2(3.63 \%)$ & 55 \\
& Total & $66(70,97 \%)$ & $23(24,73 \%)$ & $4(4,3 \%)$ & 93 \\
\hline 2005 & Inicio da estação & $8(44,44 \%)$ & $10(55,56 \%)$ & $0(0 \%)$ & 18 \\
& Primeiro pico & $19(35,85 \%)$ & $34(64,15 \%)$ & $0(0 \%)$ & 53 \\
& Segundo pico & $8(30,77 \%)$ & $14(53,85 \%)$ & $4(15,38 \%)$ & 26 \\
\hline & Total & $35(36,08 \%)$ & $58(59,80 \%)$ & $4(4,12 \%)$ & 97 \\
\hline
\end{tabular}

Outro fator de perda de ovos e morte dos filhotes foi o "stress" por calor excessivo. Em Guararitama, no dia mais quente quando a temperatura do ar atingiu $29,5^{\circ} \mathrm{C}$, em 2004 , foram encontrados três filhotes mortos sem sinais de agressão e os demais filhotes estavam extremamente apáticos, com a respiração acelerada. Essa taxa corresponde a 6,1\% da mortalidade observada nos filhotes deste ano. Já no ano de 2005 houve um atraso na postura dos ovos e uma alta taxa de predação, porém não foram observados filhotes mortos por excesso de calor nos dias em que a ilha foi visitada. 
Com base nos dados de precipitação e temperatura do ar da Base Metereológica de Iguapé (Ceptec/Inpe) (www.cptec.inpe.br), o ano de 2005 foi um ano com inverno mais quente e seco (temperature do ar entre 2004 e 2005 teste $t=8,78 \mathrm{p}=0,000$; precipitação $\mathrm{t}=0,53 \mathrm{p}=0,59)$.

Os ninhegos de L. dominicanus cresceram aceleradamente até serem capazes de voarem. No quinto dia de vida, os filhotes já estavam andando pela colônia se tornando mais visíveis aos predadores, nesta fase foram encontrados alguns filhotes mortos com bicadas na cabeça, o que pode ter sido decorrente de bicadas de outros adultos da própria espécie. Muitas vezes foi observado adultos bicando filhotes, quando esses cruzavam seus territórios reprodutivos, a procura de sombra e proteção na vegetação. Com 30 dias de vida os filhotes estavam grandes o suficiente para serem capturados por predadores, como gaviões, e após quarenta dias da eclosão os filhotes já estavam voando e procurando seu próprio alimento. O crescimento dos filhotes foi acelerado, seguindo uma regressão linear $[\mathrm{y}=68,50(\mathrm{~g})+17,03(\mathrm{~g}) *$ dias de vida $]$ (Figura 5). Com base nessa curva de crescimento foi calculado a idade de cada filhote capturado e recapturado ao longo das estações reprodutivas de 2004 e 2005. Assim foi possível estimar o crescimento da asa, do metatarso e do bico dos ninhegos (Figura 6).

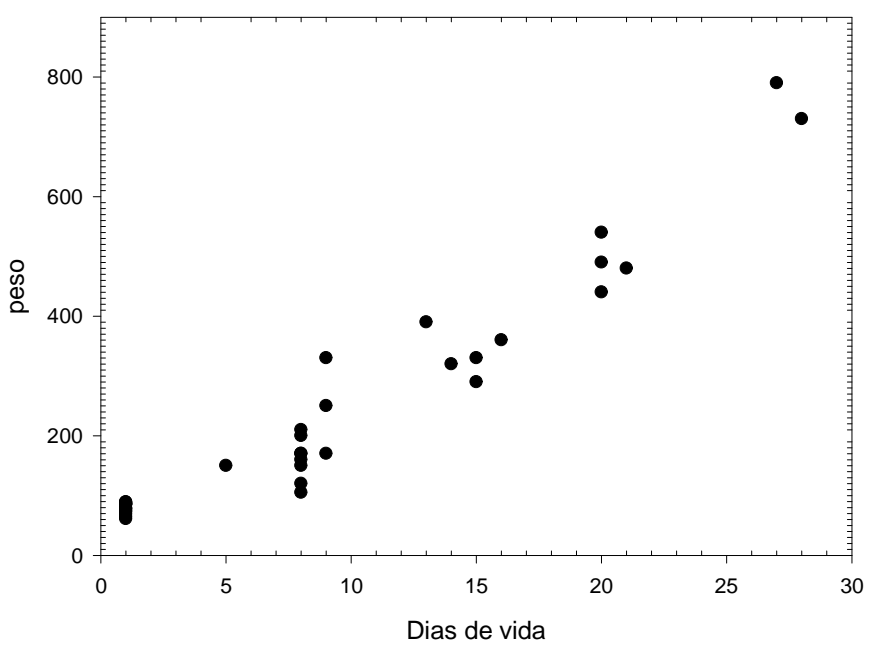

Figura 5.: Curva de crescimento dos filhotes de Larus dominicanus na Ilha de Guararitama, SP, Brazil $\left(n=17 ; r^{2}=0,97\right)$. 

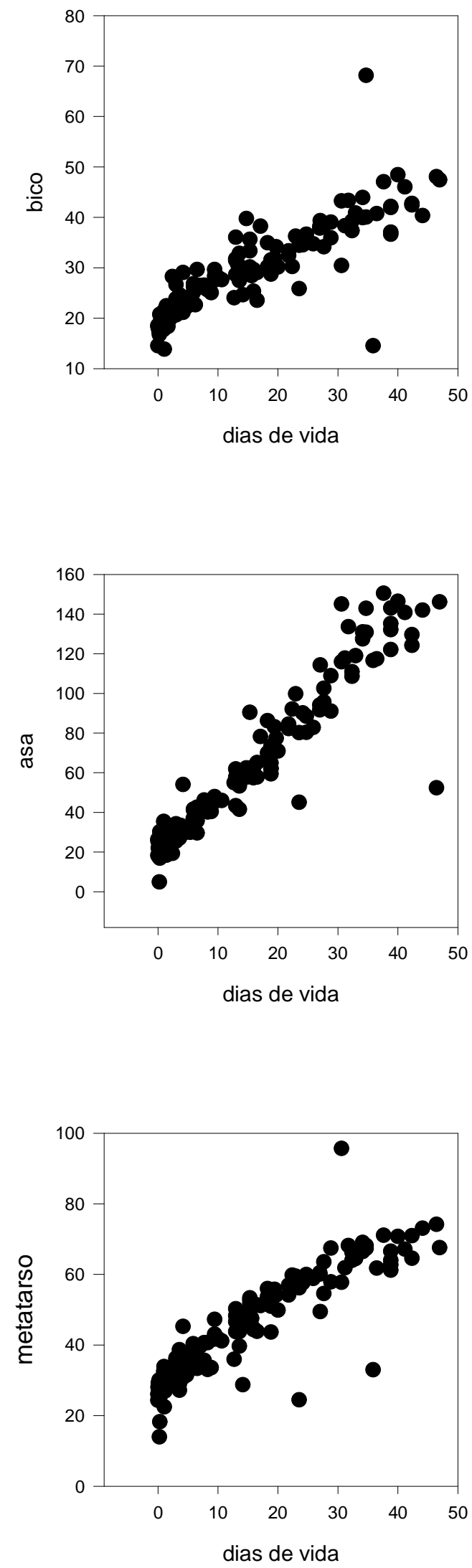

Figura 6.: Crescimento do (a) bico ( $\mathrm{mm}$ ): (b) asa (mm); (c) metatarso (mm) dos ninhegos de Larus dominicanus na Ilha de Guararitama, SP. 


\section{DISCUSSÃO}

Em São Paulo, o período reprodutivo de Larus dominicanus foi similar nos dois anos, começou no início de junho e terminou no início de novembro. Este padrão já havia sido observado em São Paulo e em Laguna, Santa Catarina (CAMPOS et al. 2004, SOARES \& FONSECA-SCHIELFLER, 1995). Na Argentina, esta espécie se reproduz no meio de Outubro na Península Valdez (YORIO \& BORBOROGLU, 2002) e de Novembro a Janeiro no centro e no Norte da Patagônia (BORBOROGLU \& YORIO, 2004). YORIO e BORBOROGLU (2002) dizeram que a estação reprodutiva de $L$. dominicanus está diretamente relacionada com a latitude, com a gaivotas reproduzindo primeiro nas colônias do norte.

O tamanho da ninhada de 1 a 3 ovos de Larus dominicanus foi registrado para essa espécie na Argentina e na África do Sul (BORBOROGLU \& YORIO, 2004; SALIVA \& BURGUER, 1989) e para outras espécies de Larus nas regiões temperadas (KLADEC \& DRURY, 1968; PAYNTER, 1949). Entretanto, o tamanho médio de ninhada encontrado neste estudo (2,09 em 2004 e 1,95 em 2005) foi menor que o encontrado na Patagônia Argentina (2,3-2,5 ovos: YORIO \& BORBOROGLU, 2002), e no Sul do Brasil (2,3 ovos SOARES \& FONSECA SCHIEFFER, 1995) e Península Antártica (2,5 ovos: FRASER, 1989).

No presente estudo a postura dos ovos foi assincrônica, sendo observado dois picos em Guararitama em ambos os anos. YORIO e BORBOROGLU (2002) na Argentina e SALIVA e BURGUER (1989) na África do Sul observaram uma postura sincrônica. A diferença no tamanho da ninhada e no período reprodutivo pode estar relacionada à localização das colônias reprodutivas, sendo influenciada pela latitude, temperatura e disponibilidade de alimentos. A ilha de Guararitama esta localizada próxima ao limite de distribuição geográfica norte dessa espécie na costa brasileira, podendo não apresentar as melhores condições ecológicas para a reprodução da mesma. 
A qualidade dos ovos pode ser definida em relação ao seu tamanho, peso e composição nutricional (MEATHREL \& RYDER, 1987). E os tamanhos dos ovos estão relacionados com a capacidade da fêmea em conseguir recursos no período anterior à postura (HERBERT \& BARCLAY, 1988). Durante cada estação reprodutiva foram observados significativas diferenças nos volumes dos ovos entre os dois picos de posturas (Fig 3). No início da estação ovos foram maiores em relação ao final da estação reprodutiva. Isto pode ser devido aos casais que se reproduzem no começo a estação serem mais experientes que os casais que se reproduzem no final da estação reprodutiva. Uma outra explicação para este padrão pode estar relacionada à capacidade competitiva dos indivíduos, assim os indivíduos que se reproduzem mais tarde ao longo da estação reprodutiva seriam os mais fracos competitivamente para conseguir bons sítios de nidificação no ótimo da estação reprodutiva. SKÓRKA et al. (2005) têm mostrado que no final da estação reprodutiva há uma redução na quantidade de comida disponível, prejudicando a fase de cuidado parental. Os casais que se reproduzem tardiamente estocam menos alimento ao longo da fase de cuidado parental e estes autores atribuem isso a indivíduos jovens e inexperientes.

Normalmente, no início da estação reprodutiva há uma maior disponibilidade de comida e melhores condições para reprodução. Assim, é esperado que os ovos do ínicio da estação sejam maiores, o que foi corroborado pelos nossos resultados. Por outro lado, em 2005 foi observado um menor volume dos ovos em relação à estação de 2004 $(t=1,99 ; p=0,046)$. Esta diferença pode ser reflexo das condições ambientais observadas ao longo dessas estações, que podem ter influenciado a sobrevivência dos filhotes. O estresse causado pelo excesso de calor é uma das principais causas de mortalidade de filhotes e perda de ovos (SALZMAN, 1982). É sabido que, as melhores temperaturas para o desenvolvimento do embrião é $37^{\circ} \mathrm{C}$ a $38^{\circ} \mathrm{C}$ e que temperaturas acima de $40.5^{\circ} \mathrm{C}$ 
são fatais (GILL, 1994). A temperatura do ar na estação reprodutiva de 2004 variou entre $17^{\circ} \mathrm{C}$ a $36^{\circ} \mathrm{C}$, e em 2005 variou de $17,5^{\circ} \mathrm{C}$ a $40^{\circ} \mathrm{C}$ (fonte: Estação Meterológica de Iguapé). BORBOROGLU e YORIO (2004) observaram que a estação reprodutiva de Larus dominicanus em Isla Vernacci, Argentina, termina no meio de janeiro, quando as temperaturas alcançam os $40^{\circ} \mathrm{C}$ e os filhotes já estavam voando. SALZMAN (1982) observou que temperatures acima de $32^{\circ} \mathrm{C}$ foram prejudiciais aos filhotes de Larus occidentalis, os levando à morte. Talvez a alta taxa de mortalidade observada em 2005 em Guararitama tenha sido devido às altas temperaturas observadas através do inverno desse ano.

Aves marinhas usam diferentes estratégias para proteger seus ninhos e filhotes do calor excessivo. Entre elas a escolha de sítios de nidificação em lugares com cobertura vegetacional tem sido utilizada por muitas espécies de Larídeos, inclusive por Larus dominicanus (BORBOROGLU \& YORIO, 2004). Adultos também costumam fazer sombras sobre os ninhos durante o período de recesso de incubação, adicionalmente molham as penas e umidecem os ovos para resfriá-los em momentos de muito calor. (GILL, 1994). Assim podemos observar que a temperatura é um fator crucial para o sucesso reprodutivo das aves, e pode ser um fator limitante do período de incubação para este grupo.

Entretanto, em Guararitama os dados do presente estudo indicaram que a principal causa de mortalidade de ovos $(25,6 \%)$ e de filhotes $(34,8 \%)$ em 2004 , e de ovos $(69,9 \%)$ e filhotes $(25 \%)$ em 2005 , foi a predação de ovos por urubus e a morte por injúrias em filhotes causadas por adultos da mesma espécie. BORBOROGLU e YORIO (2004) já haviam observado a predação de filhotes de gaivotas por adultos da mesma espécie. Estes autores acreditam que a predação de filhotes pela mesma espécie se deve à invasão dos territórios reprodutivos, quando os filhotes buscam abrigo e sombra na 
vegetação. A predação pode ser reduzida pelo cuidado parental e por seleção de sítios para nidificação mais escondidos (BORBOROGLU \& YORIO, 2004). Outros predadores já foram observados se alimentando de ovos e/ou filhotes de gaivotão, entre eles podemos citar as Skuas (Catharacta antartica) e o gavião Carcaras (Caracara plancus) (SICK, 1997; SIGRIST, 2005; YORIO et al., 1995). Em Guararitama não foi observado a formação de creche em Larus dominicanus, como já foi observado para outras espécies de Larídeos (YORIO et al., 1996).

Os filhotes de Gaivotão apresentaram um rápido crescimento e essa espécie mostrou cuidado parental durante o período de incubação e alimentação dos filhotes. BORBOROGLU e YORIO (2004) dizeram que o cuidado parental reduz gradualmente ao longo da estação reprodutiva, o que aumentaria o risco de predação. Os filhotes de $L$. dominicanus se movimentam ao redor do ninho com poucos dias de vida (aproximadamente 5 dias), o que parece ser uma característica comportamental do grupo (YORIO et al., 1996). Porém, essa movimentação ao longo da ilha faz com que os filhotes sejam mais visíveis para os predadores. Com 35 dias de vida, os filhotes já estão pesando $800 \mathrm{~g}$ e já são capazes de voarem. Nesta fase, os filhotes são agéis o suficiente para serem capturados pelos predadores. YORIO e BORBOROGLU (2002) também observou um rápido crescimento dessa espécie em colônias na costa Argentina.

Dessa forma, podemos concluir com este trabalho que Larus dominicanus reproduz durante o inverno da costa brasileira devido às altas temperaturas que o verão alcança. Já que temperaturas elevadas seriam prejudiciais para o desenvolvimento do embrião e sobrevivência dos filhotes. A postura dos ovos foi assincrônica, apresentando dois picos de postura ao longo da estação reprodutiva. A principal causa de mortalidadede ovos e filhotes em Guararitama foi a predação, principalmente por urubus e outros indivíduos adultos de própria espécie. O crescimento acelerado dos 
filhotes aumenta a probabilidade de sobrevivência dos mesmos, tornando-os capazes de escaparem dos predadores. Embora, a alta taxa de predação observada em 2005 (ano mais quente), esta espécie tem mostrado consideráveis taxas de sobrevivência (54\% em 2004 e 58\% em 2005). Se todos os filhotes que sobreviveram a estes estágios inciais de vida chegarem a fase adulta, significa que há um potencial incremento anual de $50 \%$ nas populações dessa espécie. Este aumento acelerado no tamanho populacional dessa espécie pode ser um sério problema para a conservação das aves marinhas na costa brasileira. Entretanto, estudos que consigam estimar a sobrevivência dos filhotes após abandonarem os ninhos até a fase reprodutiva ainda precisam ser realizados, para que as estimativas de sobrevivência dessa espécie não seja superestimada. 


\section{CAPITUlO II}

\section{RAZÃO SEXUAL DE LARUS DOMINICANUS NA COSTA BRASILEIRA}

\section{INTRODUÇÃO}

Larus dominicanus é uma espécie residente na costa brasileira, que não apresenta dimorfismo sexual (SICK, 1997). A razão sexual é a proporção de machos e fêmeas em uma população. Este é um dos principais parâmetros populacionais necessários para a caracterização da biologia reprodutiva e desenvolvimento de planos de manejo.

Mudanças na razão sexual são geralmente associadas a fatores ecológicos como a presença de ajudantes de ninhos e crescimento diferenciado entre os sexos (CLUTTON-BROCK et al., 1985). Diferenças no custo energético para o desenvolvimento de macho e fêmea é o principal fator que poderia influenciar a razão sexual primária (fase dos ovos) e secundária (fase dos filhotes) em organismos dióicos (PIANKA, 1999). Em mamíferos e aves com dimorfismo sexual, machos crescem mais rápido do que fêmeas, dessa forma necessitariam de mais nutrientes para o crescimento (CLUTTON-BROCK et al., 1985). Entretanto, a seleção natural beneficia país que investem em filhos e filhas do mesmo modo (TRIVERS \& WILLARD, 1973).

A diferença na razão sexual reflete a história de vida dos organismos, como a competição por espaço e alimento, a capacidade de escapar de predadores. A razão sexual pode ser afetada pelo sistema de acasalamento, pelos mecanismos de determinação de sexo, pela redução do tamanho das populações e por atividades antrópicas (caça diferenciada) (FRANKHAM et al., 2002).

As diferenças entre os números de machos e fêmeas dentro de uma população influenciam o tamanho efetivo da população, pois determinam o número de casais que se formaram na estação reprodutiva e a contribuição de cada indivíduo na geração 
seguinte. Quando a razão sexual desvia da proporção 1:1 pode ocorrer aumento da endogamia, a perda da variabilidade genética e consequentemente do "fitness". Dessa forma, o conhecimento da razão sexual de uma população é essencial para o desenvolvimento de um efetivo plano de manejo de uma espécie. Portanto, a determinação de sexos através de técnicas moleculares se fazem necessárias para espécies que não apresentam dimofirmos sexual, como Larus dominicanus.

Em aves, as fêmeas são heterogaméticas (ZW) e os machos são homogaméticas (ZZ) (GRIFFITHS et al., 1998). O cromossomo W tem sido considerado análogo ao cromossomo $\mathrm{Y}$ dos mamíferos, no que diz respeito à morfologia cromossômica, apresentando alta taxa evolutiva e podendo ser utilizado como marcador genético para estudos de filogenia de espécies próximas (FRIDOLFSSON et al., 1998). As aves e os mamíferos têm cromossomos sexuais separados o que permitiu o isolamento de marcadores sexuais específicos (SHELDON, 1998). As primeiras técnicas de sexagem molecular em aves eram feitas com um simples conjunto de primers utilizados nas reações em cadeia de polimerase (PCR) para amplificação dos locus dos cromossomos sexuais. Infelizmente, os produtos dessas reações apresentavam o mesmo tamanho, sendo necessário o uso de enzimas de restrição para diferenciá-los (GRIFFITHS et al., 1998). GRIFFITHS et al. (1998) desenvolveram um conjunto de primers que amplificam simultaneamente parte dos introns dos genes $\mathrm{CDH}-\mathrm{W}$ (Chromobox Helicase DNA binding) e CHD-Z que normalmente revela polimorfismo de tamanho entre cópias CHD dos dois genes sexuais. Assim, os produtos são corridos diretamente em gel de eletroforese, as fêmeas apresentam duas bandas e os machos apresentam uma. Marcadores desse tipo têm sido utilizados em uma ampla gama de estudos de razão sexual de aves (SHELDON, 1998). 


\section{OBJETIVO}

O objetivo desse presente trabalho foi determinar a razão sexual secundária das populações de Larus dominicanus na costa brasileira e na Ilha Rei George (Península Antartica), por meio de técnicas moleculares.

\section{MATERIAIS E MÉTODOS}

Área de estudo

Este estudo foi realizado em nove ilhas do litoral brasileiro e na Ilha Rei George (Península Antártica). Os indivíduos foram capturados com pucá, anilhados com anilhas cedidas pelo CEMAVE/IBAMA, durante as estações reprodutivas de 2001 a 2005. As coletas dessas amostras foram feitas pela equipe do LABEC, do Fausto Campos do Instituto Florestal de São Paulo, do Professor Dr. Joaquim Olinto Branco da Univale e na Antartica pela equipe do Professor Martin Sander da Unisinos.

Sexagem

Foram coletados aproximadamente $0,2 \mathrm{ml}$ de sangue da veia braquial com seringa de insulina dos indivíduos capturados. O sangue foi conservado em etanol 100\% a uma temperatura $4^{\circ} \mathrm{C}$ para posteriores análises em laboratório. Esta técnica não causa prejuízo ou morte de nenhum indivíduo. As amostras foram estocadas no acervo do Laboratório de Biologia Evolutiva e Conservação de Vertebrados, do Departamento de Genética e Biologia Evolutiva, IB-USP. O DNA foi extraído do tecido sanguíneo com utilização da técnica convencional de digestão com proteinase K e posterior purificação com fenol/clorofórmio (Sambrook et al., 2001).

Nas reações de PCR foram utilizados os primers P2 e P8 (GRIFFTHIS et al., 1998), em volumes finais de $10 \mathrm{ul}$, contendo $60-70 \mathrm{ng}$ de DNA, $1 \mu \mathrm{M}$ de cada primer, $0,4 \mathrm{mM}$ de cada dNTP, 0,5U de Taq polimerase, tampão $1 \mathrm{X}$ da taq e 2,5 $\mathrm{mM} \mathrm{MgCl}_{2}$. Os ciclos 
começam a $94^{\circ} \mathrm{C}$ por $1 \mathrm{mim}$, seguido de 35 ciclos de $94^{\circ} \mathrm{C}$ por 30 segundos, $48^{\circ} \mathrm{C}$ por 45 segundos, $72^{\circ} \mathrm{C}$ por 45 segundos, terminando com $72^{\circ} \mathrm{C}$ de extensão final por 5 mim. Os produtos de PCR foram separados em gel de agarose a 3\% e corados com brometo de etídeo.

\section{Análises estatísticas}

A razão sexual foi comparada com a frequência esperada de 1:1 através do teste qui-quadrado em cada ilha e em cada ano amostrado (Bioestat AYRES et al., 1998).

\section{RESULTADOS}

Ao todo foram sequenciados 172 individuos, sendo que desde 84 são macho e 88 são fêmeas. As amplificações de Larus dominicanus revelaram duas bandas para as fêmeas de tamanho aproximado de 230 pb e 260 pb e uma banda para os macho de tamanho aproximado de $230 \mathrm{pb}$. Foi determinado o sexo de 106 indivíduos do Estado de São Paulo, 39 individuos do Estado de Santa Catarina e 13 indivíduos da Península Antártica.

Todas as populações amostradas não apresentaram desvio da proporção esperada de 1:1 (Tabela IV). Mesmo quando essas populações foram analisadas em diferentes anos como a população de Guararitama.

\section{DISCUSSÃO}

Larus dominicanus não apresentou desvio da razão sexual secundária esperada de 1:1 nas oito ilhas amostradas no litoral brasileiro e na ilha Rei George (Península Antártica). Essa é uma espécie de ampla distribuição no Hemisfério Sul, que vem apresentando grande expansão populacional nas últimas décadas (QUINTANA \& YORIO, 1998). Muitos pesquisadores têm relacionado essa grande expansão populacional à capacidade dessa espécie de se alimentar de diversos tipos de recursos alimentares, como restos pesqueiros, resíduos antrópicos e através da predação de outras 
espécies de aves marinhas (YORIO et al., 1998). Assim, esta uma espécie generalista que vem se adaptando muito bem a ocupação da costa brasileira. A disponibilidade de alimentos não seria um fator limitante para o desenvolvimento de nenhum dos dois sexos.

Tabela IV.: Razão sexual de Larus dominicanus nas ilhas do Litoral Brasileiro

\begin{tabular}{lccccc}
\hline \multicolumn{1}{c}{ População } & $\mathbf{N}$ & $\hat{\jmath} \overline{0}$ & $q q$ & $\chi^{2}$ & $\mathbf{P}$ \\
\hline Guararitama - SP (2001) & 25 & 13 & 12 & 0,0400 & 0,8415 \\
Guararitama- SP (2003) & 24 & 9 & 15 & 1,6000 & 0,2058 \\
Guararitama- SP (2004) & 21 & 10 & 11 & 0,0476 & 0,8272 \\
Queimadinha- SP (2001) & 15 & 5 & 10 & 1,6667 & 0,1966 \\
Laje da Conceição- SP (2001) & 14 & 7 & 7 & 0,0000 & 1,0000 \\
Laje de Santos- SP (2001) & 17 & 9 & 8 & 0,0588 & 0,8083 \\
Itacolomis- SC (2002) & 2 & 0 & 2 & 2,0000 & 0,1572 \\
Tambores- SC (2002) & 11 & 4 & 7 & 0,8182 & 0,3656 \\
Moleques do Sul- SC (2002) & 12 & 9 & 3 & 3,0000 & 0,0832 \\
Ilha Deserta- SC (2002) & 8 & 5 & 3 & 0,5000 & 0,4794 \\
Ilha dos Lobos- SC (2002) & 6 & 5 & 1 & 2,6667 & 0,1024 \\
\hline Península Antártica (2004/2005) & 13 & 8 & 5 & 0,6923 & 0,4053 \\
\hline Total & $\mathbf{1 7 2}$ & $\mathbf{8 4}$ & $\mathbf{8 8}$ & $\mathbf{0 , 0 9 3 0}$ & $\mathbf{0 , 7 6 0 0}$
\end{tabular}

Entretanto, pouco se sabe sobre a biologia reprodutiva dessa espécie. Acredita-se que como outras espécies de gaivotas Larus dominicanus seja uma espécie monogâmica e que não apresentam ajudantes no ninho. Nada sabemos sobre o desenvolvimento dos filhotes ou se o custo de investimento em ambos os sexos é similar. NAGER et al. (2000) estudando outra espécie do gênero Larus fuscus observou que os machos são maiores e que as fêmeas, e estas apresentam menor sobrevivência na fase de ovos, suportando a idéia que os filhotes machos estariam sobre desvantagem de sobrevivência sobre pobres condições de recursos alimentares. Porém, Larus fuscus é uma espécie que apresenta dimorfismo sexual. GONZALES-SOLIS et al. (2005) estudando Sterna hirundo, que é uma espécie com sutil diferença de tamanho entre os sexos, observaram 
que os filhotes machos e fêmeas eclodiram de ovos com similares volumes, mas durante a fase de cuidado parental a mortalidade foi maior para os machos.

FISHER (1973) afirmou que o investimento parental deveria ser igual para os dois sexos, devido à segregação independente dos cromossomos, que produziriam proporções similares de machos e fêmeas. Assim, qualquer diferença observada na razão sexual de uma população seria resultado de sua história de vida. Ao mesmo tempo a seleção natural favoreceria pais que investissem da mesma forma nos dois sexos, já que o desvio da proporção sexual 1:1 leva à redução da variabilidade genética e consequentemente do fitness reprodutivo (TRIVERS \& WILLARD, 1973). Acredita-se que aves marinhas sejam monogâmicas e que ambos os sexos participam do cuidado parental (DELHOYO, 1996). Entretanto, Larus dominicanus não apresenta dimorfismo sexual e sua população vem apresentando uma grande expansão populacional. Estudos mais aprimorados que busquem verificar essa importante característica populacional são importantes para a conservação, sendo este parâmetro um bom indicador de como os organismos estão respondendo as mudanças ambientais. Muitos trabalhos têm observado que o custo de investimento dos pais na geração e no cuidado da prole difere entre os sexos (CLUTTON-BROCK et al., 1985). Dessa forma, sob condições ambientais extremas, fêmeas de diferentes espécies com dimorfismo sexual podem alimentar mais um sexo. Este fato tem sido comprovado em diversos trabalhos que observaram uma maior mortalidade de machos (CLUTTON-BROCK et al., 1985; NAGER et al., 2000) ou de fêmeas sobre condições adversas (TORRES \& DRUMMOND, 1997; DIJKSTRO et al., 1998).

A disponibilidade de alimento, locais de nidificação e a presença de materiais para confecção de ninhos são alguns fatores ambientais que influenciam o sucesso reprodutivo das aves. Porém alguns autores acreditam que a qualidade nutricional dos 
pais é o principal fator que afeta o desenvolvimento dos filhotes desde a fase do ovo (HOYT, 1979; VEDDER et al., 2005). A capacidade dos pais de alimentarem os filhotes após a eclosão e suprí-los se reflete na razão sexual secundária da espécie. Pais inexperientes ou indivíduos com baixa qualidade nutricional podem aumentar seu fitness selecionando o sexo de menor custo reprodutivo, enviesando a razão sexual dos filhotes na fase de cuidado parental (TRIVERS \& WILLARD, 1973).

Assim, dados de razão sexual são extremamente importantes para estudos populacionais, mas poucos estudos têm sido desenvolvidos com espécies da costa brasileira, principalmente espécies sem dimorfismo sexual. Trabalhos que busquem elucidar como o ambiente afeta a razão sexual das espécies, para a manutenção da variabilidade genética e do fitness reprodutivo das mesmas são fundamentais para o desenvolvimento de estratégias e planos de manejo. Nesse trabalho concluímos que $L$. dominicanus não apresenta desvio da razão sexual,o que é consistente com seu elevado sucesso reprodutivo e expansão populacional nas últimas décadas. 


\section{CAPITULO III}

\section{VARIABILIDADE GENÉTICA DE LARUS DOMINICANUS NA COSTA BRASILEIRA, UTILIZANDO DNA MITOCONDRIAL}

\section{INTRODUÇÃO}

A variabilidade genética permite que as populações mantenham seu "fitness" e a capacidade de responder às mudanças ambientais (MORITZ, 2002). A variação genética dentro e entre as populações é fundamental para a manutenção dos processos evolutivos (ZINK et al., 1987, MACCAULEY, 1991).

Populações naturais são dinâmicas em muitas dimensões, mudam de tamanho, densidade e localização em função do tempo, e em função do espaço as populações podem fragmentar-se em muitas subpopulações ou fundir-se com outras (HEY \& MACHADO, 2003). Populações de muitas espécies são frequentemente subdivididas por fatores geográficos, ecológicos e comportamentais (GENOVART et al., 2003).

As populações fragmentadas podem apresentar-se com diversas estruturas: (1) como populações inteiramente isoladas sem nenhum fluxo gênico; (2) como vários agrupamentos entre os quais o fluxo gênico é suficiente para que se comportem como uma única e grande população genética, (3) seguindo o modelo de ilhas onde a taxa migração é igual entre ilhas de igual tamanho e distância; (4) de acordo com o modelo de "stepping-stones", onde há fluxo gênico entre populações vizinhas; (5) baseado no modelo fonte-sumidouro, onde há uma ilha maior que é fonte de migração de indivíduos para ilhas menores e (6) e seguindo o modelo de metapopulações, onde há várias populações com frequentes eventos de extinção e recolonização (BEGON et al. 1996, FRANKHAM et al., 2002).

O fluxo gênico é dependente da taxa de migração entre as populações. E a taxa de migração depende do número de populações que se encontram dentro da região, da 
distribuição geográfica, do padrão espacial, da distância entre elas e da habilidade de dispersão da espécie (FRANKHAN et al., 2002). O fluxo gênico entre os grupos homogeniza a variação genética entre eles (GENOVART et al., 2003). Quando a taxa de fluxo gênico é baixa ou nula os efeitos da deriva podem ser mais facilmente visíveis na diferenciação das populações (SLATKIN, 1987).

Estudos de genética de populações vêm aumentando consideravelmente nas últimas décadas (BALLARD \& WHITLOCK, 2004). Marcadores moleculares têm sido amplamente aplicados para acessar a repartição genética entre as populações geograficamente isoladas, para definir unidades significativamente evolutivas abaixo do nível de espécies, para propostas de manejo e conservação e para revisar tradicionais designações de espécies e subespécies (MORITZ, 2002).

A variação genética filogeográfica é um importante fator para a conservação, determinando a contribuição de cada subpopulação para a diversidade genética de uma população ou espécie (MORITZ, 2002). A resolução de limites filogeográficos entre as populações tem se tornado essencial para o estabelecimento de prioridades de conservação e para a avaliação de estratégias de manejo para espécies ameaçadas (TARR \& FLEISCHER, 1999). A biodiversidade pode ser perdida quando os limites das populações não são conhecidos (TARR \& FLEISCHER, 1999).

Os marcadores mitocondriais têm sido extensivamente usados em estudos de populações (GENOVART et al., 2003, BROWN et al., 2004, HELBIG \& SEIBOLD, 1999, AVISE et al., 2000, AUSTIN et al., 1994). As mitôcondrias contêm centenas de cópias de único tipo de molécula de DNA circular, que é maternalmente herdada em muitas espécies (FRANKHAN et al., 2002). O DNA mitocondrial pode ser dividido em várias regiões, entre elas encontramos a região codificadora do ATPase e a região codificadora do citocromo b (MINDELL et al., 1998). ATPase 8 é a segunda região 
mais variável do DNA mitocondrial de aves, porém muito curta (165-168 pb) (SORENSON, 2003). O citocromo b é uma região bem conservada, com taxa de substituição estimada de $2 \%$ por milhão de anos (Myr) (BRIDGE et al., 2005).

Larus dominicanus é uma espécie de grande capacidade competitiva, que tem deslocado várias outras espécies de aves marinhas dos seus sítios reprodutivos (QUINTANA \& YORIO, 1998). No hemisfério Norte há muitos trabalhos que investigam a hibridação, a sistemática e a filogenia de várias espécies de Larideos (CROCHET et al., 2002; LIEBERS et al., 2004; PONS et al., 2004). Entretanto, na América do Sul estudos que busquem elucidar a estrutura genética e a variabilidade desse grupo são inexistentes. Este é o primeiro trabalho realizado com Larus dominicanus na costa brasileira e na América do Sul, que busca elucidar a variabilidade genética e estrutura populacional dessa espécie. Somente através de estudos de variabilidade genética da espécie, podemos definir grupos e regiões importantes para conservação. Com base nesses resultados poderemos propor aos órgãos responsáveis um efetivo plano de manejo para espécies de aves marinhas na costa Brasileira.

\section{OBJETIVOS}

Este trabalho visa descrever aspectos da variabilidade genética e da estrutura populacional de Larus dominicanus no litoral brasileiro, através do uso de marcadores mitocondriais, comparando o litoral brasileiro com outras localidades de sua distribuição. 


\section{METODOLOGIA}

Área de estudo e captura dos indivíduos

Este estudo foi realizado em oito ilhas do litoral brasileiro e uma ilha subantárticas (Tabela V). As capturas foram realizadas durante a estação reprodutiva de 2002, 2003, 2004 e 2005, essas amostras encontram-se depositadas no banco de amostras do Laboratório de Biologia Evolutiva e Conservação de Vertebrados (IBUSP). Os indivíduos foram capturados com puçá, anilhados com anilhas cedidas pelo CEMAVE/IBAMA (Licença 1060). Foram realizadas coletas também na ilha Rei George, Península Antártica, no verão austral de 2004/2005, pela equipe do Professor Martin Sander (Unisinos, RS). Neste estudo, também foram usadas sequências disponíveis no "Genbank" (www.ncbi.nlm.nih.gov) provenientes das ilhas Kerguelen Island e Nova Zelândia.

Tabela V.: Ilhas amostradas na costa brasileira e Península Antártica com o tamanho amostral de cada população de Larus dominicanus.

\begin{tabular}{l|c|c} 
Ilhas & Localização geográfica & Tamanho amostral \\
\hline Laje da Conceição & $24^{\circ} 14^{\prime} \mathrm{S} 46^{\circ} 41^{\prime} \mathrm{W}$ & 7 \\
\hline Guararitama & $24^{\circ} 23^{\prime} \mathrm{S} 46^{\circ} 59^{\prime} \mathrm{W}$ & 20 \\
\hline Queimadinha & $24^{\circ} 22^{\prime} \mathrm{S} 46^{\circ} 48^{\prime} \mathrm{W}$ & 7 \\
\hline Tambores & $26^{\circ} 22^{\prime} \mathrm{S} 48^{\circ} 31 \mathrm{~W}$ & 10 \\
\hline Itacolomis & $26^{\circ} 40^{\prime} \mathrm{S} 48^{\circ} 19^{\prime} \mathrm{W}$ & 7 \\
\hline Moleques & $27^{\circ} 51^{\prime} \mathrm{S} 48^{\circ} 26^{\prime} \mathrm{W}$ & 12 \\
\hline Deserta & $27^{\circ} 16^{\prime} \mathrm{S} 48^{\circ} 19^{\prime} \mathrm{W}$ & 8 \\
\hline Lobos & $28^{\circ} 26^{\prime} \mathrm{S} 48^{\circ} 42^{\prime} \mathrm{W}$ & 16
\end{tabular}

\section{Coleta de Sangue e Extração de DNA}

Foram coletados aproximadamente $0,2 \mathrm{ml}$ de sangue da veia braquial dos indivíduos capturados. O sangue foi conservado em etanol $100 \%$ a uma temperatura $4^{\circ} \mathrm{C}$ 
para posteriores análises em laboratório. Esta técnica não causa prejuízo ou morte de nenhum indivíduo. As amostras foram estocadas no acervo do Laboratório de Biologia Evolutiva e Conservação de Vertebrados do Departamento de Biologia, IB-USP. O DNA foi extraído do tecido sanguíneo com utilização da técnica convencional de digestão com proteinase $\mathrm{K}$ e posterior purificação com fenol/clorofórmio (SAMBROOK et al., 2001).

\section{Variabilidade Genética dentro e entre as populações}

Para o estudo de variabilidade genética as amostras foram aplificadas através dos primers Lys (5'-CAGCACTAGCCTTTTAAGCT-3') e int- $H$ (5'TGGGATtAGATGTTTGTTG-3') para o gene da ATPase 6 e 8; os primers L15008 (5'AACTTCGGATCTCTACTAGG-3') e H1532b (5'-GAATAAGTTGGTGATGACTG-3') para o citocromo b. As reações para os fragmentos da ATPase 8 e 6 e citocromo b foram preparadas para um volume final de $10 \mu$ por tubo, contendo 10X tampão da Taq polimerase (10mM Tris- $\mathrm{HCl}, \mathrm{pH} 8,3,50 \mathrm{mM} \mathrm{KCl}), 2,5 \mathrm{mM} \mathrm{MgCl}_{2}, 2 \mathrm{mM}$ de cada dNTPs, 1 pmol de primer, 0,5u de Taq polimerase e cerca de 20 ng de DNA. Os ciclos começam a $94^{\circ} \mathrm{C}$ por 5 minutos, seguido de 35 ciclos de 45 segundos a $94^{\circ} \mathrm{C}, 30$ segundos a $58^{\circ} \mathrm{C}$ e 45 segundos a $72^{\circ} \mathrm{C}$ e 10 minutos de extensão final a $72^{\circ} \mathrm{C}$.

Os produtos da PCR foram purificados através de EXO-SAP e as sequências foram obtidas usando BigDye terminator (version 3.1) (Applied Biosystems), utilizando os mesmo primers das PCRs. O alinhamento das sequências foram feitas com auxílio do programa Bioedit version 5.0.6 (HALL, 2001). A diversidade Haplotípica (h) e a diversidade nucleotídica (П) foi determinada através do programa DNAsp (ROZAS et al., 2003). O programa Network 3.1 software foi utilizado para gerar a rede de haplótipos (ROHL, 2000). 


\section{RESULTADOS}

Um fragmento de 312 bp do gene do citocromo $b$ foi sequenciado em 83 indivíduos da costa brasileira, 7 indivíduos da Península Antártica e 5 indivíduos das ilhas Marion. Estas sequências foram comparadas com sequências disponíveis no “GenBank” provenientes da Nova Zelândia (NC006007, AY293619, AF268497) e da ilha Kerguelen (AF444259). Na costa Brasileira, Larus dominicanus apresenta somente um único haplótipo e as sequências da Península Antártica, Ilhas Marion, Kerguelen e Nova Zelândia apresentam um outro haplótipo, divergindo em apenas um nucleotídeo (Fig 8). A diversidade haplotípica para este fragmento é 0,273 e a diversidade nucleotídica $(\pi)$ é 0,00087 .

A região codificadora da ATPase 8 e 6 foi sequenciada $(600 \mathrm{pb})$ para 58 indivíduos de Larus dominicanus da costa brasileira. Nesta amostragem encontramos 3 haplótipos $(\mathrm{h}=0.358$ and $\Pi=0.00063)$ que também se diferenciam somente por uma mutacão. Estas sequências foram comparadas com sequências disponíveis no Genbank provenientes da Nova Zelândia (NC006007, AY293619), que apresentaram o haplótipo mais abundante da costa brasileira (H1) (Fig 9). 

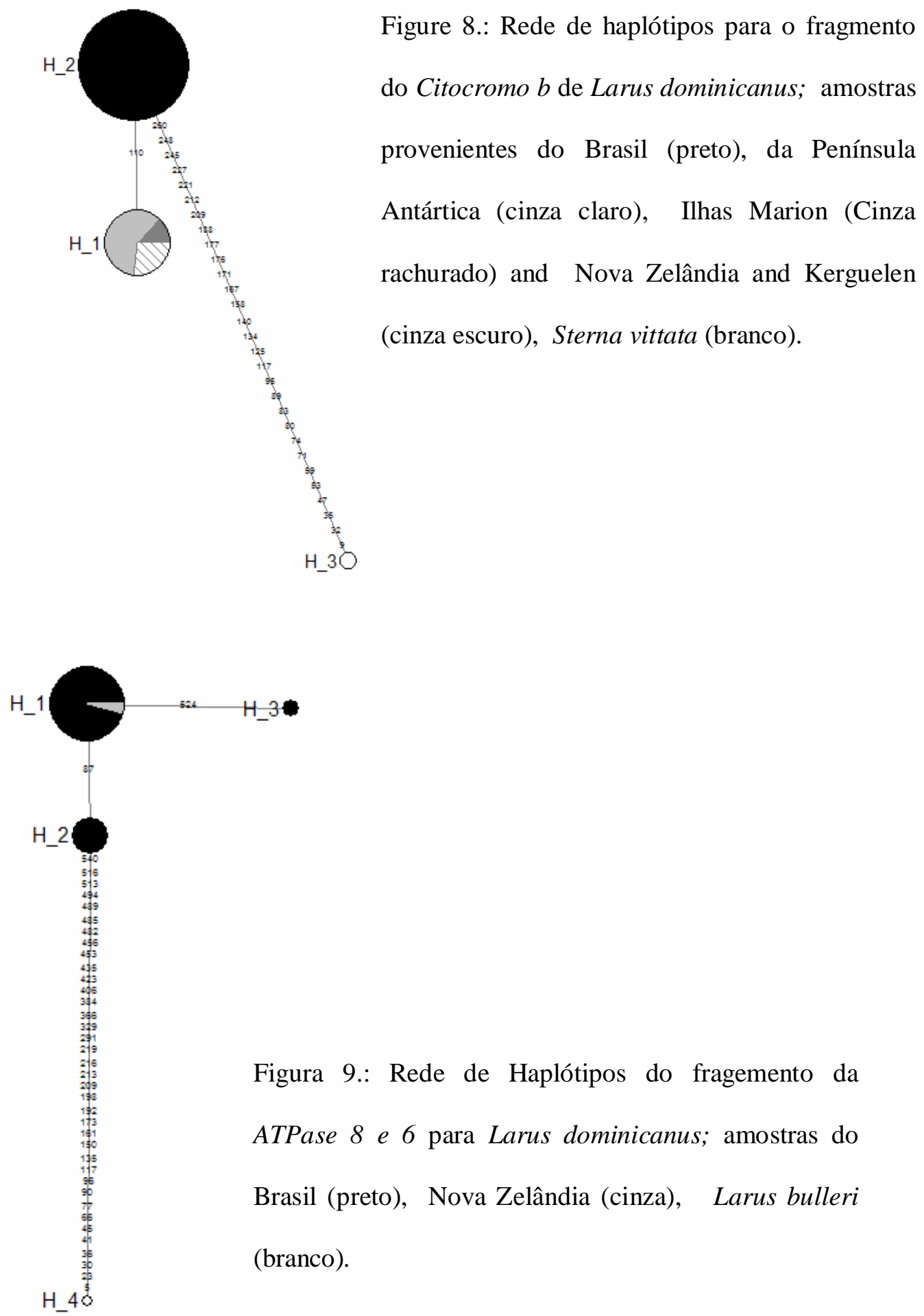


\section{DISCUSSÃO}

A baixa variabilidade genética observada em Larus dominicanus é extremamente preocupante do ponto de vista da conservação, uma vez que a variação genética permite que as populações respondam às mudanças ambientais e resistam a doenças e pestes (FRANKHAM et al., 2002). Baixa diversidade genética pode ser explicada por fatores demográficos ou forças seletivas (GALTIER et al., 2000). Fatores demográficos incluem gargalos populacionais e efeitos do fundador, ambos os processos envolvem uma redução temporária do tamanho populacional, resultando no aumento do efeito da deriva gênica. Por outro lado, a rápida fixação de um novo e favorável alelo através da seleção direcional (varredura seletiva), também gera uma queda da variabilidade genética em loci ligados (GALTIER et al., 2000). A redução da variabilidade genética pode transformar uma espécie mesmo que abundante, em uma espécie com alta probabilidade de extinção por eventos estocásticos.

Mecanismos de diferenciação de aves marinhas de ampla distribuição e de alta vagilidade são pouco conhecidos (CONGDOM et al., 2000). Fatores como forte filopatria, grandes distribuições geográficas ou separações históricas podem permitir uma substancial diferenciação genética de algumas espécies (GENOVART et al., 2003). Acredita-se que as aves possuam suficientes níveis de filopatria para que ocorra a diferenciação das populações, porém essa divergência não tem sido observada em muitas espécies (AUSTIN et al., 1994; FIESEN et al., 1996). Além disso, para a maioria das espécies de aves marinhas, eventos vicariantes e barreiras extrínsecas para a dispersão são inexistentes ou limitados a um pequeno número de eventos (CONGDOM et al., 2000). Apesar de alguns estudos terem mostrado baixa variabilidade genética e estrutura populacional em aves marinhas, pouco se sabe sobre os processos históricos e demográficos que levaram aos padrões observados atualmente. 
Recentes estudos filogeográficos de aves marinhas de altas latitudes indicam que muitas populações se divergiram em alopatria durante o Pleistoceno em refúgios glaciais, como é o caso Cepphus columba e C. grylle (KIDD \& FRIESEN, 1998). Muitas populações de albatrozes parecem ter divergido na ausência de qualquer obvia barreira física para o fluxo gênico (BURG \& CROXALL, 2001). LIEBERS et al. (2001) afirmaram que os ciclos glaciais no Pleistoceno associado às mudanças ecológicas afetaram a dinâmica das populações de gaivotas no Hemisfério Norte.

Sabe-se que o nível do mar apresentou oscilações durante as glaciações do Quarternário (BIGARELLA, 1965). Na costa brasileira, o nível do mar chegou a subir mais de 10 metros acima do nível atual (SUGUIO, 2004) e há evidências que no Pleistoceno houve regressões de cerca de 100 metros abaixo do nível atual (BIGARELLA, 1965). Os efeitos dessas flutuações do nível do mar na separação e diferenciação de populações marinhas ainda não é conhecido.

Estudos têm mostrado que o surgimento do Istmo do Panamá, e as correntes oceânicas, como a corrente de Benguela e a corrente de Agulhas podem atuar como barreira para o fluxo gênico entre populações de ampla distribuição por diversos continentes (STEEVES et al., 2005a). Porém, não se conhece barreiras físicas para o fluxo gênico no Oceano Atlântico (STEEVES et al., 2005b). Entretanto, estudos com Sula dactylatra apresentam um claro padrão filogeográfico dentro do oceano Atlântico (STEEVES et al., 2005b) apesar da pequena amostragem nessa bacia oceânica.

A falta de estrutura observada tanto no citocromo $b$ como na ATPase 6 e 8 , sugerem que o fluxo gênico entre os sítios reprodutivos de Larus dominicanus sejam grande o suficiente para que essas colônias se comportem como uma única e grande população. A capacidade de dispersão das aves pode explicar a falta ou a pequena diferenciação genética frequentemente encontrada entre as populações reprodutivas 
(AUSTIN et al., 1994; AVISE et al., 2000). UNDERHELL (2002) estudando a subespécie Larus dominicanus vetula, na Africa do Sul, observaram que essa espécie geralmente retorna a suas colônias natais para reproduzir. ORO e PRADEL (1999) relataram que a probabilidade dos indivíduos reproduzirem em colônias não natais declina com a distância. Dessa forma, esperávamos encontrar algum grau de diferenciação entre os sítios reprodutivos, já que L.dominicanus reproduz ao longo de cerca de $2000 \mathrm{~km}$ de costa no Brasil.

Outra explicação para a baixa diferenciação dessa espécie na costa brasileira é que a colonização nessa região seja recente. Colônias onde todos os indivíduos são descendentes de um pequeno grupo fundador podem apresentar baixa diversidade genética (efeito do fundador) (HARTL \& CLARCK, 1989). GENOVART et al. (2003) estudando colônias de Larus audouinnii observaram que a colônia de Ebro Delta era uma colônia formada recentemente por imigrantes da Ilha de Chafarinas, Mar Mediterrâneo, e não apresentava diferenciação significativa quando comparadas com a colônia natal.

Considerando essa hipótese levantamos duas possíveis origens para as populações de Larus dominicanus residentes no Brasil. A população original poderia ter sido formada por migrantes das ilhas do Oceano Pacífico da América do Sul ou das colônias do Sul da África e Austrália. Porém, de qualquer forma os indivíduos teriam que utilizar as ilhas Sub-Antárticas e Península Antártica para alcançarem a costa brasileira, que apresentaria uma colonização na bacia do Oceano Atlântico no sentido Sul-Norte. Entretanto, nossos dados mostram uma baixa diferenciação genética mesmo quando comparados com amostras do "GenBank" provenientes da Austrália, Nova Zelândia e Ilha Kerguelen. Essa região apresenta um haplótipo diferente de $C y t b$, mas o mesmo haplótipo da ATPase 6 e 8. 
A baixa variabilidade genética de L. dominicanus em uma distribuição geográfica tão grande, em conjunto com estudos de PONS et al. (2004) e CROCHET et al. (2002) que mostraram que a variabilidade genética é extremamente baixa no DNA mitocondrial do grupo Laridae, nós levou a considerar a hipótese de varredura seletiva no DNA mitocondrial desse grupo.

Entretanto a amostragem de um grande número de loci não ligados espalhados pelo genoma, permitirá distinguir entre as hipóteses de eventos seletivos ou demográficos (AKEY et al., 2004; GALTIER et al., 2000). Devido ao fato dos eventos demográficos afetarem todos os loci do genoma de maneira similar, enquanto que eventos de seleção atuam sobre locos específicos (AKEY et al., 2004). Assim, o desenvolvimento de marcadores nucleares são necessários para elucidar a história demográfica das populações de gaivotas e identificar os padrões filogeográficos das mesmas. 


\section{CAPITULO IV}

\section{COMPARAÇÃO DOS PADRÕES FILOGEOGRÁGFICOS REVELADOS POR MARCADORES MITOCONDRIAIS E NUCLEARES EM GAIVOTAS}

\section{INTRODUÇÃO}

Muitos trabalhos com aves marinhas têm mostrado baixa diferenciação genética dentro das espécies, apesar dessas espécies apresentarem filopatria (AVISE et al., 2000; AUSTIN et al., 2000). Entretanto, poucos trabalhos tentaram elucidar a história evolutiva dessas espécies abordando análises de múltiplos loci. Grande parte dos trabalhos disponíveis na literatura são resultados de marcadores mitocondriais ou microsatélites (PONS et al,. 2004; BURG \& CROXALL, 2004).

Os microsatelites têm sido considerados excelentes marcadores para estudos populacionais, devido a sua alta taxa mutacional e grande diversidade, sendo extensivamente utilizados para avaliar eventos demográficos recentes como gargalos populacionais (LUIKART \& COURNUET, 1998). Entretanto, esse tipo de marcador não permite traçar as genealogias das populações e assim determinar os padrões históricos dos eventos que moldaram a variabilidade genética do grupo. Dessa forma, o uso de marcadores de microsatelites é valioso dentro de um cenário previamente conhecido.

Por outro lado, marcadores mitocondriais têm sido extensivamente usados em estudos populacionais, devido às suas características como a alta taxa de evolução, por conterem genes conservados através de amplo limites taxonômicos e pela existência de primers universais, permitindo assim um fácil acesso a um grande número de taxons (PALUMBI \& BAKER, 1994; MOORE, 1995). Além disso, características genéticas 
dos marcadores mitocondriais permitem que sua interpretação seja de mais fácil aplicação em relação a marcadores nucleares.

O genoma mitocondrial e nuclear diferem de muitos modos, tal como a ploidia, o modo de herança, o grau de recombinação, número de introns, tamanho efetivo populacional, taxa de mutação e mecanismos de reparação (BALLARD \& WHITLOCK, 2004).

Genes mitocondriais são haplóides e herdados uniparentalmente (linhagem materna), enquanto os marcadores nucleares são diplóides e de herança biparental. Estas características têm duas importantes implicações na interpretação dos dados populacionais. A primeira é que os dados gerados de marcadores mitocondriais contam um parte da história evolutiva da espécie, refletindo os efeitos dos processos históricos nas populações de fêmeas. Os marcadores diploides, como marcadores nucleares, podem revelar de forma mais acurada a história evolutiva da população ou espécie por refletir a história da população como um todo (machos e fêmeas) (PALUMBI \& BAKER, 1994, ZHANG \& HEWITT, 2003, BALLARD \& WHITLOCK, 2004)..

Além disso, a diferença na ploidia em conjunto com o modo de herança desses marcadores terão um efeito direto na interpretação dos dados devido à diferença do tamanho efetivo dessas moléculas. Como o DNA mitocondrial é uma molécula haplóide e de herança materna, para cada cópia de DNA mitocondrial passado para próxima geração quatro cópias de DNA autossomo são passadas. Essa desigualdade faz com que o DNA mitocondrial fixe novos alelos por deriva genética quatro vezes mais rápido do que o DNA nuclear (BALLARD \& WHITLOCK, 2004). Dessa forma, populações que passaram por eventos de gargalos populacionais ou colonização recente apresentarão grande perda de variação genética e uma rápida fixação de alelos, e esse efeito tende a ser visto com mais nitidez em marcadores mitocondriais. Por outro lado, se estes 
eventos tiverem ocorrido há muito tempo atrás na história evolutiva da espécie, marcadores mitocondriais podem ser ineficientes para detectar essas informações, devido ao seu número efetivo ser $1 / 4$ do nuclear, consequentemente seu tempo de coalescência será muito menor (MOORE, 1995).

Outra diferença marcante entre esses dois marcadores é a presença ou não de recombinação. A recombinação distorce a história contada pelas sequências dos haplótipos, produzindo falsas inferências filogeográficas baseadas nas genealogias (ZHANG \& HEWITT, 2003). Uma vez que as inferências são feitas da comparação entre os haplótipos e consideram que haplótipos iguais tenham a mesma origem e a diferença entre os haplótipos sejam devido a eventos aleatórios de mutação. Diversas inferências de processos evolutivos são baseados em métodos de reconstrução filogenéticas que têm como pressuposto a ausência de recombinação (BALLARD \& WHITLOCK, 2004). Marcadores mitocondriais não apresentam recombinação para muitos grupos animais, o que permite que as inferências feitas através de seus dados sejam um reflexo dos eventos históricos que atuaram sobre a população. Entretanto, uma consequência da ausência de recombinação é que qualquer evento que afete uma parte da molécula diretamente influenciará a molécula por completo. O que significa que a utilização de diferentes marcadores mitocondriais não são independentes e podem refletir a mesma história da população (BALLARD \& WHITLOCK, 2004). Por outro lado, marcadores nucleares frequentemente apresentam recombinação. Entretanto, de acordo com ZHANG e HEWITT (2003) não é comum encontrarmos regiões nucleares onde a taxa de recombinação é maior que a taxa de mutação.

Com o advento de novas técnicas moleculares e o desenvolvimento de novos marcadores têm contribuído para responder a principal questão dos estudos de genética de populações, que é compreender os processos que geram e mantêm o polimorfismo 
genético, e assim entender os mecanismos de evolução a nível populacional. KIMURA (1968) formulou o modelo da teoria neutra, que diz que a variação genética a nível molecular é considerada neutra e a extensão da variação é determinada primariamente pela taxa de mutação e pelo efetivo tamanho populacional (NEI \& KUMAR, 2000). Dessa forma, a comparação da quantidade de variação genética observada e esperada dentro de uma população ou uma espécie pode nos revelar muito sobre a história evolutiva de um grupo (NEI \& KUMAR, 2000). Por exemplo, a seleção, acasalamentos/cruzamentos não aleatórios, subdivisão de população podem desviar as frequências genotípicas do esperado, causando desvios significativos.

Além disso, dados haplotípicos intra-específicos, como a divergência alélica, a frequência alélica e o número de alelos são parâmetros chaves para refletir diferentes aspectos das populações e suas histórias evolutivas. Por exemplo, para locus neutros a divergência alélica associada à genealogia refletem eventos evolutivos que ocorrem sob longos períodos de tempo e desde de antes da especiação; a frequência de alelos está relacionada à idade dos alelos sob a teoria de coalescência e o número de alelos ao tamanho das populações (ZHANG \& HEWITT, 2003).

Após diversos trabalhos desenvolvidos com marcadores mitocondriais muitos pesquisadores observaram que inferências baseada em único gene (locus) nem sempre será capaz de responder às questões levantadas (BALLARD \& WHITLOCK, 2004; PALUMBI \& BAKER, 1994). Dessa forma, a melhor estratégia para muitos organismos é a análise de múltiplos locus independentes distribuídos pelo genoma.

A natureza generalista de Larus dominucanus, associado à sua capacidade de colonizar novos ambientes faz com que seja necessário elucidar a estrutura populacional dessa espécie na costa brasileira. Nossos resultados por meio de marcadores mitocondriais demonstraram que Larus dominicanus apresentam níveis extremamente 
baixos de variabilidade genética (DANTAS et al., 2006). Dessa forma, o desenvolvimento de marcadores nucleares se tornou uma importante ferramenta para elucidar a história demográfica e evolutiva das populações dessa espécie de gaivota. Baixos níveis de variabilidade genética podem ser resultado de eventos demográficos ou eventos seletivos. Para diferenciar entre esses eventos o uso e múltiplos marcadores não ligados é imprescindível (SLATKIN \& MADDISON, 1990, SLATKIN \& HUDSON, 1991; PALUMBI \& BAKER, 1994). A concordância de padrões filogenéticos de múltiplos locus provê uma confiável visão da estrutura de populações. Eventos demográficos como gargalos populacionais marcam o genoma como um todo, por outro lado eventos seletivos marcaram somente o locus sob seleção e loci ligados a este.

Dessa forma, procuramos através desse trabalho desenvolver marcadores que fossem informativos para estudos populacionais de Larus dominicanus e assim tentar recuperar a história evolutiva do grupo.

\section{OBJETIVOS}

O objetivo do presente estudo foi desenvolver marcadores nucleares que fossem informativos para estudos populacionais em gaivotas, de forma que pudéssemos responder questões sobre a estrutura populacional e a história evolutiva de Larus dominicanus na costa brasileira.

\section{Objetivos específicos:}

1) desenvolver marcadores nucleares para que possam ser utilizados em estudos populacionais de Larus dominicanus.

2) Comparar a variabilidade genética presente no genoma nuclear em relação ao genoma mitocondrial 
3) Através da análises de múltiplos locus inferir os processos históricos que moldaram a baixa variabilidade genética observada no DNA mitocondrial de Larus dominicanus.

\section{METODOLOGIA}

\section{Seleção de marcadores nucleares}

Nesse trabalho foram utilizados marcadores nucleares previamente desenvolvidos pelo CIBIO (Centro de Investigação em Biodiversidade e Recursos Genéticos) da Universidade do Porto para estudos com Perdizes. Concomitantemente foram desenhados marcadores nucleares utilizando a técnica EPIC (Exon Primers Intron Cross) desenvolvida por PALUMBI \& BAKER (1994). Para este trabalho foram desenhados primers tendo como base o genoma completo da Galinha (Gallus gallus) disponível no "Genbank" (www.ncbi.nlm.nih.gov). Os primers foram desenhados nos exons que flanqueiam introns (EPIC) (Figura 10), considerando que "exons" normalmente são regiões mais conservadas, sujeitas a forte pressão seletiva, o que facilita que primers desenhados nessa região possam ser utilizados em estudos inter específicos. As regiões de interesse de amplificação nesse trabalho foram diversos “introns" por serem regiões mais variáveis em relação aos exons e por se comportarem geralmente como regiões neutras (PRIMER et al., 2002). Dessa forma, os primers foram desenhados procurando atender as seguintes características: (1) o tamanho dos primers varia de 15 a $20 \mathrm{pb}$ para que possam ser utilizados tanto nas reações de cadeia de polimerase (PCR) como em reações de sequenciamento; (2) os primers são equilibrados entre si, ou seja, tanto o primer inverso como o reverso apresentam similares proporções de AT/CG para que suas temperaturas de anelamento sejam próximas; (3) a ponta $3^{\prime}$ dos primers começam com CC/CG/GG de forma que sua ligação na fita de interesse seja uma ligação forte; (4) foi dada uma atenção especial 
para que as sequências dos primers não sejam complementares entre as pontas ou entre eles, para evitar primers diméricos.

\section{Gene Nuclear}

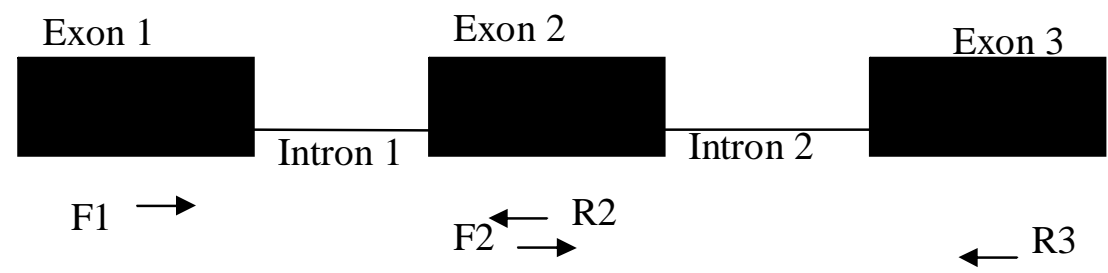

Figura 10.: Esquema de desenho dos primers em regiões de exons para amplificar regiões de introns. F1primer foward que se liga ao exon 1 para amplifar o intron 1, o R2 é o primer reverso que se liga ao exon 2 para amplificar o intron 1; F2 primer foward que se liga ao exon 2 para amplifar o intron 2, o R3 é o primer reverso que se liga ao exon 3 para amplificar o intron 2

Ao todo foram testados 33 introns localizados em diferentes genes de diferentes cromossomos para garantir que esses marcadores não estariam ligados (Anexo I- lista de todos os genes e primers testados). Deu-se preferência para genes que não compunham família multigênica, para evitar que fossem amplificados múltiplas cópias nucleares.

\section{Reações de PCR teste dos primers e seleção dos genes}

As reações de PCR foram feitas para um volume final de 10 ul contendo (50mM Tris-HCl, 50mM NaCl, pH 8.5); 200uM dNTPs , 0.5U de Gotaq DNA polymerase (Promega), 5 pmol de cada primer e um gradiente de magnésio $1,5 \mathrm{mM}$ a $3,0 \mathrm{mM}$ e aproximadamente 50ng de DNA. Os os ciclos da reação de cadeia de polimerase começam com desnaturação of 5 min a $95^{\circ} \mathrm{C}$, seguido de 38 ciclos de $30 \mathrm{~s}$ a $95^{\circ} \mathrm{C}, 45 \mathrm{~s}$ a um gradiente de temperatura especifica de cada primer (ANEXO I), 1 min a $72{ }^{\circ} \mathrm{C}$ e extensão final de $7 \mathrm{~min}$ a $72{ }^{\circ} \mathrm{C}$. Os produtos de PCRs foram aplicados em gel de Agarose $2 \%$, e as reações que apresentaram boas amplificações com bandas nítidas e 
únicas foram sequenciadas. Os produtos de PCR foram purificados através de EXOSAP e sequenciados através BigDye 3.1 no sequenciador da Applied Biosystems 3100 DNA, seguindo recomendações dos fabricantes. Após o sequencimento essas sequências foram editadas no ChromasLite 3.1 (Technelysion) e alinhadas no BioEdit (HALL, 1999). Para conferir se o produto do sequenciamento se referia ao gene do nosso interesse e não a cópias nucleares presentes no genoma foi feito um BLAST da sequência no "Genbank".

Após a padronização das amplificações, 13 genes foram selecionados para o estudos das genealogias populacionais (Tabela IV). Para estes genes foram realizados PCRs em um conjunto de indivíduos procedentes de toda a distribuição de Larus dominicanus no Brasil e uma localidade da Ilha Rei George (Península Antártica). Foram amplificados e sequenciados pelo menos 5 indivíduos de cada macro-região estudada (São Paulo, Santa Catarina, Península Antártica). Essas amostras foram sequenciadas, as sequências foram alinhadas com auxílio do Bioedit (HALL, 1999) e a definição dos haplótipos mais prováveis foi feita pelo programa PHASE (STEPHENS et al., 2001). Os haplótipos definidos pelo PHASE foram utilizados para as inferências filogenéticas e os estudos populacionais.

\section{Estimativas de variabilidade}

Estimativas de polimorfismo do DNA foram calculadas considerando o modelo de finitos sítios. As seguintes medidas foram estimadas: número de haplótipos, diversidade haplotípica (a probabilidade que dois haplotipos aleatórios sejam diferentes em uma amostra), diversidade nucleotídica $(\pi)$ é a média da diversidade nucleotídica por sítio entre duas sequencias; a estimativa de Theta (por sitio baseada no $\pi$ ) $\theta=4 \mathrm{~N} \mu$, o Eta $(\eta)$ é o número total de mutações e o $\mathrm{S}$ é o número de sítios segregantes (sitos 
polimórficos). Todas essas medidas foram feitas através do programa DNAsp (ROZAS et al., 2003).

Tabela IV.: Genes que foram selecionados para estudos genéticos em Larus dominicanus, tamanho do fragmento em bp $(\mathrm{TF})$, número de indivíduos $(\mathrm{N})$, número de sequências (Seq), Temperatura de anneling (Ta)

\begin{tabular}{|c|c|c|c|c|c|c|}
\hline & Genes & Região & TF & $\mathrm{N}$ & Seq. & $\mathrm{Ta}$ \\
\hline ACL & ATP citrate lyase & $\begin{array}{l}\text { Cromossom0 } 27 \\
\text { (exon16-exon17) }\end{array}$ & 469 & 19 & 38 & 62.5 \\
\hline$A K 1$ & Adenylate Kinase 1 & $\begin{array}{l}\text { Cromossomo } 17 \\
\text { (exon 4- exon 6) }\end{array}$ & 890 & 12 & 24 & 60 \\
\hline$A X I N$ & AXIN Protein & $\begin{array}{l}\text { Cromossomo } 14 \\
\text { (exon } 7 \text { - exon } 8 \text { ) }\end{array}$ & 1280 & 17 & 34 & 58 \\
\hline CEPU & CEPU gene & $\begin{array}{l}\text { Cromossomo } 24 \\
\text { (exon1-exon2) }\end{array}$ & 627 & 15 & 30 & 63.5 \\
\hline$C-R M I L$ & $\begin{array}{c}\text { v-raf murine sarcoma viral } \\
\text { oncogene }\end{array}$ & $\begin{array}{c}\text { Cromossomo } \\
\text { (exon 14-exon } \\
15 \text { ) }\end{array}$ & 576 & 18 & 36 & 58 \\
\hline FIB & $\beta$ Fibrinogen & $\begin{array}{l}\text { Cromossomo } 4 \\
\text { (exon 7- exon8) }\end{array}$ & 908 & 52 & 104 & 61 \\
\hline LRPP40 & Laminin receptor precursor $\mathrm{P} 40$ & $\begin{array}{l}\text { Cromossomo } 2 \\
\text { (exon 5- exon 6) }\end{array}$ & 362 & 23 & 46 & 60 \\
\hline MPLPR & Myelin Proteolipid Protein & $\begin{array}{l}\text { Cromosomo UNK } \\
\text { (exon 4- exon5) }\end{array}$ & 356 & 24 & 48 & 61 \\
\hline$O D C$ & Ornithine decarboxilase & Cromossomo 10 & 660 & 19 & 38 & 60 \\
\hline$R A G$ & Recombination activating gene 1 & $\begin{array}{c}\text { Cromossomo } 5 \\
(\text { exon } 1)\end{array}$ & 958 & 12 & 24 & 61 \\
\hline RGS4 & $\begin{array}{l}\text { Regulator of G-protein signalling } \\
4\end{array}$ & $\begin{array}{l}\text { Cromossomo } 8 \\
\text { (exon3-exon 4) }\end{array}$ & 686 & 17 & 34 & 54 \\
\hline RPL7A & Ribosomal Protein L7A & $\begin{array}{l}\text { Cromossomo } 17 \\
\text { (exon 7- exon 8) }\end{array}$ & 485 & 10 & 20 & 63.5 \\
\hline VIM & Vimentin & $\begin{array}{l}\text { Cromossomo } 2 \\
\text { (exon 7- exon 8) }\end{array}$ & 366 & 26 & 52 & 57 \\
\hline
\end{tabular}

\section{Testes de neutralidade}

Para estimar se a variabilidades observada desvia da variabilidade esperada sob o modelo neutro foram realizados os testes D de Tajima (TAJIMA, 1989) e Fu e Li (D* e F*) (FU \& LI, 1993). 
O D de Tajima (1989) testa a hipótese de todas as mutações serem neutras. Esse teste é baseado na diferença entre o número de sítos segregantes e a média do número de diferenças par a par.

$$
\mathrm{D}=\left(\mathrm{k}-\mathrm{S} / \mathrm{a}_{1}\right) /\left[\mathrm{V}\left(\mathrm{k}-\mathrm{s} / \mathrm{a}_{1}\right)\right]^{1 / 2}
$$

\section{Onde:}

S é o número total de sítios segregantes

$\mathrm{a}_{1}=\sum(1 / \mathrm{i})$ onde $\mathrm{i}=1$ a n- $1 ; \mathrm{n}$ é o número de sequências

k é a média de diferenças nucleotídicas entre pares de sequências

Quando os genes estão evoluindo sob um regime neutro e a população está sob equilíbrio entre deriva e mutação, o $\theta=4 \mathrm{~N} \mu$ pode ser estimado por $\mathrm{p}_{\mathrm{s}} / \mathrm{a}_{1}$ ou por $\pi$. Entretanto, se há muitos alelos deletérios na população, poderíamos esperar que o $\mathrm{p}_{\mathrm{s}} / \mathrm{a}_{1}$ seja inflacionado, onde $\pi$ não seria afetado seriamente, porque o pi é afetado pela frequência dos alelos $(\mathrm{D}<0)$. Em contraste se há seleção balanceadora, que aumenta a frequência dos alelos, nós esperamos que o $\pi$ aumente, onde o $\mathrm{p}_{\mathrm{s}} / \mathrm{a}_{1}$ não sofra alteração $(\mathrm{D}>0)$.

Os testes de Fu e Li’s (D* e F) (1993) também testam a hipótese de todas as mutações serem neutras, porém baseia-se no modelo neutro de $\eta / a_{1}$, (n-1) $\eta s / n$, onde:

$\eta$ é o número total de mutações

$\mathrm{a}_{1}=\sum(1 / \mathrm{i})$ onde $\mathrm{i}=1 \mathrm{a} \mathrm{n}-1$

n é o número de sequências

k é a média de diferenças nucleotídicas entre pares de sequências

$\theta=4 \mathrm{~N} \mu$

$D^{*}$ test é baseado na diferença entre $\eta s$, o número de singletos (mutações que aparecem uma única vez) e $\eta$ (o total de mutações) e $F^{*}$ test é baseado na diferença ente $\eta s$ 
(número de singletos) e $\mathrm{K}$ a média do número da diferença nucleotídica entre pares de sequências.

A total variância molecular dentro e entre as regiões estudas de Larus dominicanus foi particionada pela Análise de Variância Molecular (AMOVA) com o auxílio do programa Arlequin ver 3.1 (EXCOFFIER et al., 1992), que baseia-se na análise de variância das frequências gênicas, mas leva em conta o número de mutações entre os haplótipos moleculares. Dessa forma, o teste analisa hierarquicamente a repartição da variância dentro dos componentes de variação (variação inter-individual ou inter-populacional). Os Fst entre pares de população também foram estimados pelo programa Arlequim para investigar as diferenças genéticas entre pares de populações, sendo seus valores de probabilidade gerados através da distribuição nula por 1000 permutações aleatórias. O número de migrantes entre pares de populações por geração foi calculado através da formula:

$$
\mathrm{Fst}=1 /(4 \mathrm{Nm}+1)
$$

A reconstrução das genealogias nucleares foram feitas para cada locus e vizualizados através de árvores de Neighbour joining, construídas através do programa MEGA 3.1 (KUMAR et al., 1993). Estas árvores não representam a verdadeira genealogia, mas permite vizualizar os agrupamentos de alelos. Análises que consideram todas as alternativas ligações e múltiplas conecções entre os haplótipos foram realizadas com auxílio do programa networking 3.1 software (ROHL, 2000).

O teste "four-gamete" e cálculos do número mínimo de recombinação ( $\mathrm{Rm}$; Hudson and Kaplan 1985) foi realizado para cada locus usando o DNASP 4.0 (ROZAS et al., 2003). 


\section{RESULTADOS}

As sequências de todos os locus sequenciados corresponderam aos fragmentos dos introns esperados. Em um conjunto de indivíduos de Larus dominicanus estes genes se revelaram altamente informativos do ponto de vista populacional. Assim neste trabalho tivemos uma eficiência de procura por genes polimórficos de 39,4\%. O que demonstra que é necessário um grande investimento financeiro e investimento de tempo para o desenvolvimento de um conjunto de marcadores nucleares para estudos populacionais em espécies não modelos.

Todos os 13 introns foram variáveis, com número de haplótipos variando de 4 a 12 por locus e número de sítios polimórficos variando de 3 a 23. Os dados de diversidade dos marcadores nucleares mostraram que estes marcadores apresentam grande variabilidade genética quando comparados ao DNA mitocondrial de Larus dominicanus (Tabela V). A diversidade haplotípica chega a ser o dobro da diversidade observada em marcadores mitocondriais e a diversidade nucleotídica $(\pi)$ é de uma ordem de grandeza acima.

Os testes de neutralidade, D de Tajima, e Fu \& Li, realizados para todos os genes não indicaram desvio das expectativas de neutralidade (Tabela VI). As análises de variância molecular (AMOVA) e o Fst por par de populações não apresentaram o mesmo padrão de estrutura populacional. Os genes ACL, AK1, AXIN, CEPU e CRM apresentam significativos valores de Fst nas Análises de Variância Molecular (Tabelas VII-XXX). Nesses genes foram observados estrutura genética entre a costa brasileira e a Península Antártica. Entretanto, os demais genes analisados, LRPP, MPL, ODC, RAG1, RGS e RPL, não apresentam significativos valores nas análises de variância molecular e nas análises de Fst por par de populações. 
As árvores filogenéticas de Neighbour joining não mostram evidência de estrutura filogeográfica entre os haplótipos e suas localidades em nenhum dos genes amostrados. As relações entre os clados apresentam suportes extremamente baixos $(<50)$. Entretanto, um fato extremamente importante de se observar é que o grupo externo utilizado nessas análises, que são compostos por diferentes espécies do género Larus que ocorrem no hemisfério norte, quase sempre apresentaram o mesmo haplótipo dos indivíduos de Larus dominicanus (Fig 11).

As análises de rede de haplótipos que levam em conta todas as associações entre os haplótipos resultaram em redes reticuladas (Figs 12-23), indicando possíveis eventos de recombinação ou homoplasia nesses genes. As redes dos genes AXIN, RGS, RPL e VIM apresentam uma forma similar, um haplótipo mais abundante e outros derivados desde, lembrando uma possível estrutura em forma estrela. Sendo que o gene RGS é ligado por um haplótipo ancestral ou não amostrado.

O teste" four-gamete" demonstrou que há indícios de recombinação nos genes AK1, AXIN, CEPU, CRM, LRPP, MPL, ODC e RAG1, sendo que o Rm (mínimo evento de recombinação) variou de 1 a 5 (Tabela V). Entretanto, os genes ACL, RGS, RPL e VIM não apresentam sinais de recombinação, passando pelo teste "four-gamete". 
Tabela V .: Genes analizados em Larus dominicanus, comparando o número de sítios polimórficos (SNP), a diversidade haplotípica (h) e a diversidade nucleotídica $(\pi)$, número mínimo de recombinação $(\mathrm{Rm})$.

\begin{tabular}{c|c|c|c|c|c} 
Gene & Tamanho & SNP & h & Pi $(\pi)$ & Rm \\
\hline Cyt B* & 315 & 1 & 0,273 & 0,00083 & 0 \\
\hline ATPase 6 e 8* & 583 & $\mathbf{2}$ & 0,358 & $\mathbf{0 , 0 0 0 6 3}$ & $\mathbf{0}$ \\
\hline ACL & 469 & $\mathbf{3}$ & $\mathbf{0 , 7 2 5}$ & $\mathbf{0 , 0 0 2 4 3}$ & $\mathbf{0}$ \\
\hline AK1 & $\mathbf{8 9 0}$ & $\mathbf{1 8}$ & $\mathbf{0 , 9 0 9}$ & $\mathbf{0 , 0 0 4 8 2}$ & $\mathbf{5}$ \\
\hline AXIN & $\mathbf{1 1 3 4}$ & $\mathbf{9}$ & $\mathbf{0 , 7 5 2}$ & $\mathbf{0 , 0 0 1 5 1}$ & $\mathbf{3}$ \\
\hline CEPU & $\mathbf{6 2 7}$ & $\mathbf{8}$ & $\mathbf{0 . 8 5 1}$ & $\mathbf{0 , 0 0 2 8 4}$ & $\mathbf{4}$ \\
\hline CRM & $\mathbf{5 8 1}$ & $\mathbf{7}$ & $\mathbf{0 , 7 8 7}$ & $\mathbf{0 , 0 0 3 6 5}$ & $\mathbf{3}$ \\
\hline FIB & $\mathbf{8 7 6}$ & $\mathbf{2 3}$ & $\mathbf{0 , 8 9 6}$ & $\mathbf{0 , 0 0 4 7 7}$ & $\mathbf{5}$ \\
\hline LRPP & $\mathbf{3 6 2}$ & $\mathbf{3}$ & $\mathbf{0 . 6 7 5}$ & $\mathbf{0 , 0 0 2 3 9}$ & $\mathbf{1}$ \\
\hline MPL & $\mathbf{3 5 4}$ & $\mathbf{1 1}$ & $\mathbf{0 , 7 9 0}$ & $\mathbf{0 , 0 0 5 9 9}$ & $\mathbf{5}$ \\
\hline ODC & $\mathbf{6 6 0}$ & $\mathbf{1 1}$ & $\mathbf{0 , 6 4 6}$ & $\mathbf{0 , 0 0 2 3 0}$ & $\mathbf{2}$ \\
\hline RAG-1 & $\mathbf{9 5 8}$ & $\mathbf{5}$ & $\mathbf{0 , 7 9 3}$ & $\mathbf{0 , 0 0 1 2 1}$ & $\mathbf{1}$ \\
\hline RGS & $\mathbf{6 8 6}$ & $\mathbf{6}$ & $\mathbf{0 , 5 7 8}$ & $\mathbf{0 , 0 0 1 1 4}$ & $\mathbf{0}$ \\
\hline RPL & $\mathbf{4 8 5}$ & $\mathbf{5}$ & $\mathbf{0 , 7 4 2}$ & $\mathbf{0 , 0 0 3 8 4}$ & $\mathbf{0}$ \\
\hline VIM & $\mathbf{3 6 6}$ & $\mathbf{3}$ & $\mathbf{0 , 4 6 6}$ & $\mathbf{0 , 0 0 1 4 0}$ & $\mathbf{0}$ \\
\hline
\end{tabular}

* genes mitocondriais 
Tabela VI.: Teste de neutralidade para os genes nucleares de Larus dominicanus.

\begin{tabular}{l|l|ll|rl} 
Gene & Fu \& Li F* & \multicolumn{2}{l}{ Fu \& Li D* } & \multicolumn{2}{l}{ D de Tajima } \\
\hline ACL & $1,2049 \mathrm{p}>0,10$ & 0,9251 & $\mathrm{p}>010$ & 1,3156 & $\mathrm{p}>0,10$ \\
\hline AXIN & $0,3704 \mathrm{p}>0,10$ & 0,7626 & $\mathrm{p}>0,10$ & $-0,0673$ & $\mathrm{p}>0,10$ \\
\hline CEPU & $-0,1667 \mathrm{p}>0,10$ & 0,0379 & $\mathrm{p}>0,10$ & $-0,5328$ & $\mathrm{p}>0,10$ \\
\hline CRM & $0,1066 \mathrm{p}>0,10$ & $-0,1917$ & $\mathrm{p}>0,10$ & 0,7259 & $\mathrm{p}>0,10$ \\
\hline MPL & $1,0853 \mathrm{p}>0,10$ & 1,4225 & $0,10>\mathrm{p}>0,05$ & $-0,4247$ & $\mathrm{p}>0,10$ \\
\hline LRPP & $0,8866 \mathrm{p}>0,10$ & 0,9134 & $\mathrm{p}>0,10$ & 0,3900 & $\mathrm{p}>0,10$ \\
\hline ODC & $-0,0726 \mathrm{p}>0,10$ & $-0,0386$ & $\mathrm{p}>0,10$ & $-1,2914$ & $\mathrm{p}>0,10$ \\
\hline VIM & $0,5411 \mathrm{p}>0,10$ & 0,5463 & $\mathrm{p}>0,10$ & $-0,4636$ & $\mathrm{p}>0,10$ \\
\hline RGS & $0,5234 \mathrm{p}>0,10$ & 1,2045 & $\mathrm{p}>0,10$ & $-1,2889$ & $\mathrm{p}>0,10$ \\
\hline AK1 & $0,3753 \mathrm{p}>0,10$ & 0,6363 & $\mathrm{p}>0,10$ & $-0,3996$ & $\mathrm{p}>0,10$ \\
\hline RAG-1 & $1,2469 \mathrm{p}>0,10$ & 0.8547 & $\mathrm{p}>0,10$ & $-0,3885$ & $\mathrm{p}>0,10$ \\
\hline RPL & $0,6390 \mathrm{p}>0,10$ & 0,3867 & $\mathrm{p}>0,10$ & 0,9852 & $\mathrm{p}>0,10$ \\
& & & & &
\end{tabular}




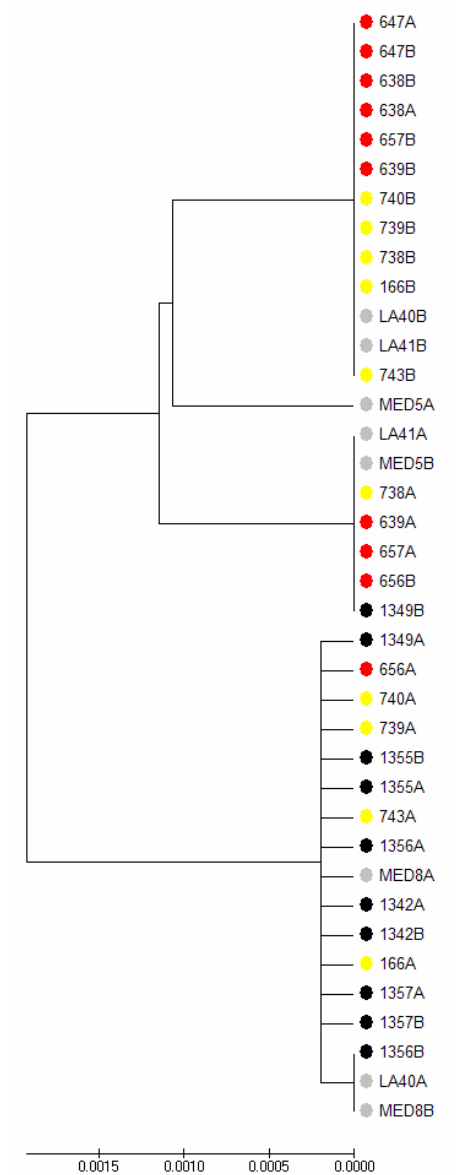

ACL

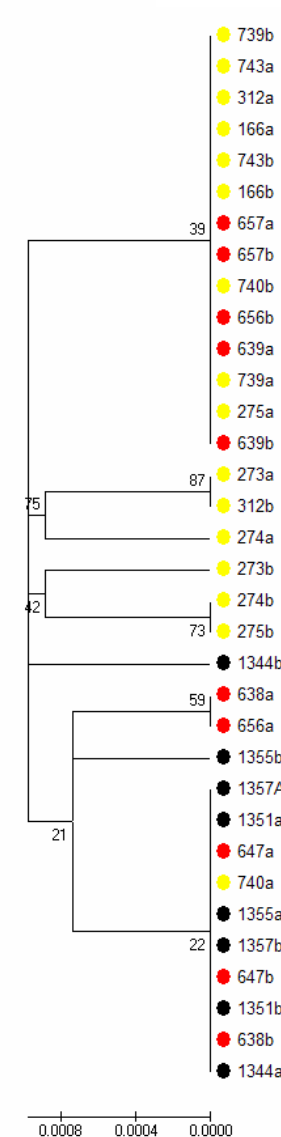

AXIN

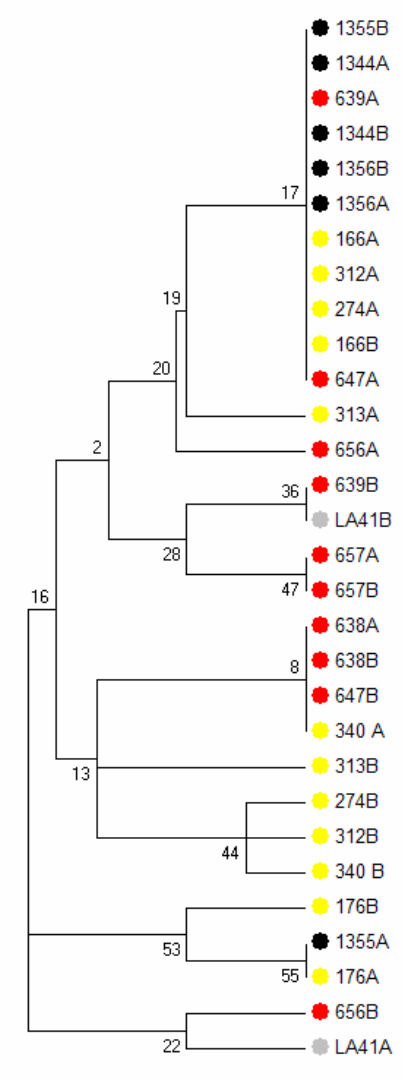

$\begin{array}{cccc}\prime & \prime & \prime & \\ 0.0015 & 0.0010 & 0.0005 & 0.0000\end{array}$

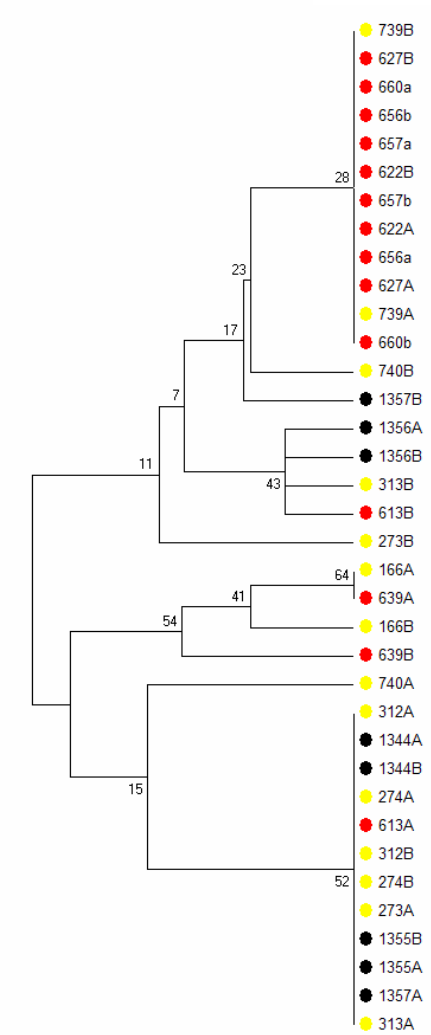

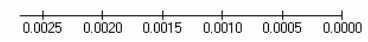

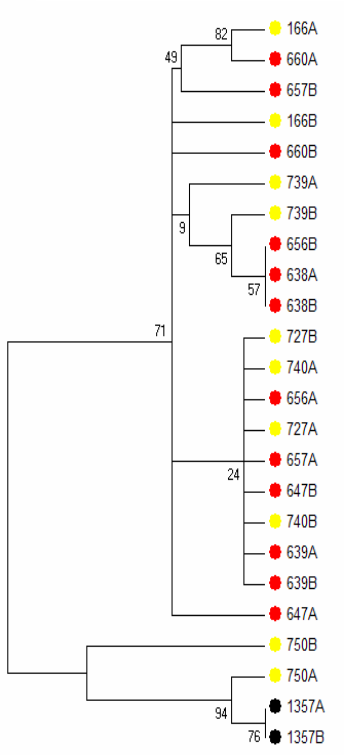

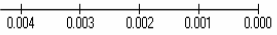

AK1

Figura 11 A: Árvore de Neighbour Joining para ao genes ACL; AXIN; CEPU, CRM, AK1, onde círculos vermelhos são amostras de Larus dominicanus provenientes de Santa Catarina, amarelo amostras de São

Paulo, preto amostras da Península Antártica e cinza amostras de grupo externo. 


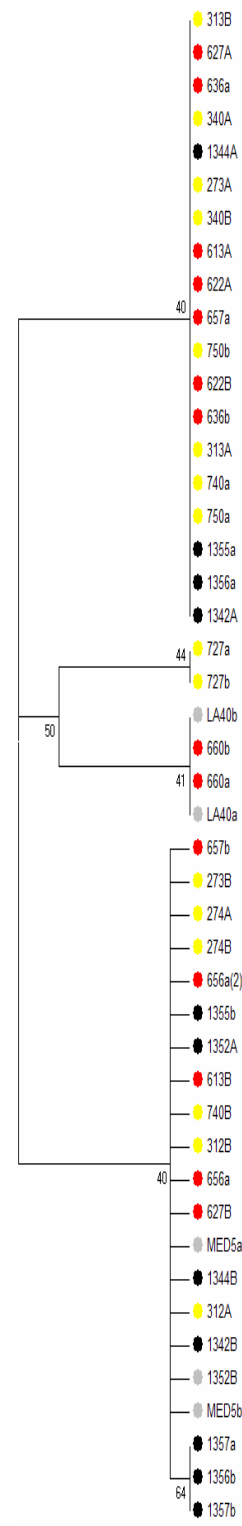

$\begin{array}{llll}\frac{1}{10.015} & \frac{1}{10010} & 0.005 & 0.0000\end{array}$
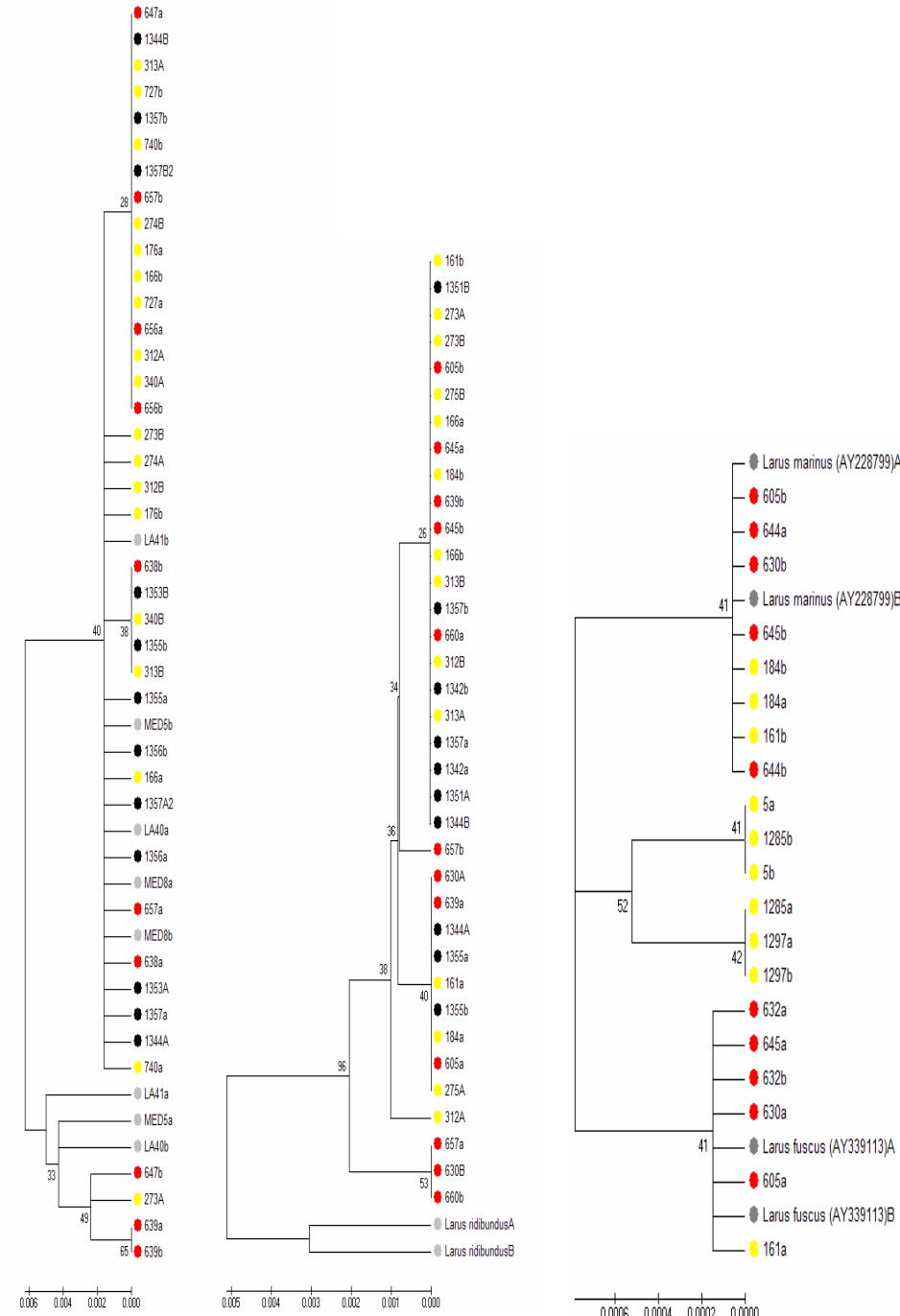

$\frac{1}{0.0006} 0.0004 \quad 0.00020 .0000$

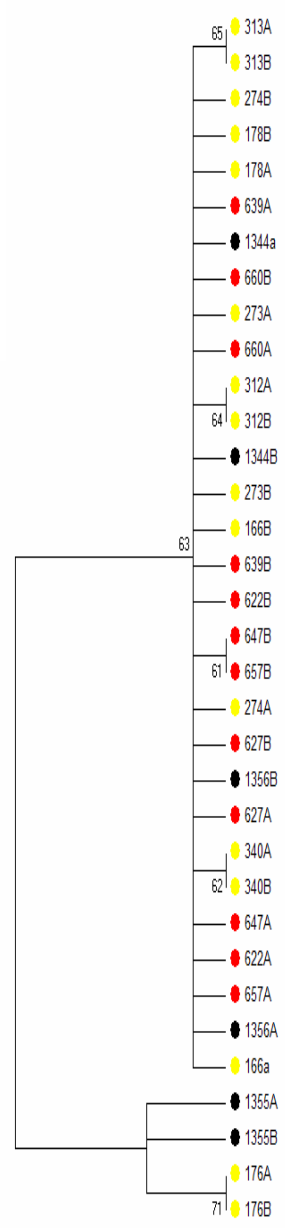

$\frac{1}{0.0012} \quad \frac{10008}{0.0004} 0.00000$

LRPP MPL

ODC

RAG1

RGS

Figura 11 B: Árvore de Neighbour Joining para ao genes LRPP; MPL; ODC, RAG1, RGS, onde círculos vermelhos são de amostras de Larus dominicanus proveniente de Santa Catarina, amarelo amostras de São Paulo, preto amostras da Península Antártica e cinza amostras de grupo externo. 

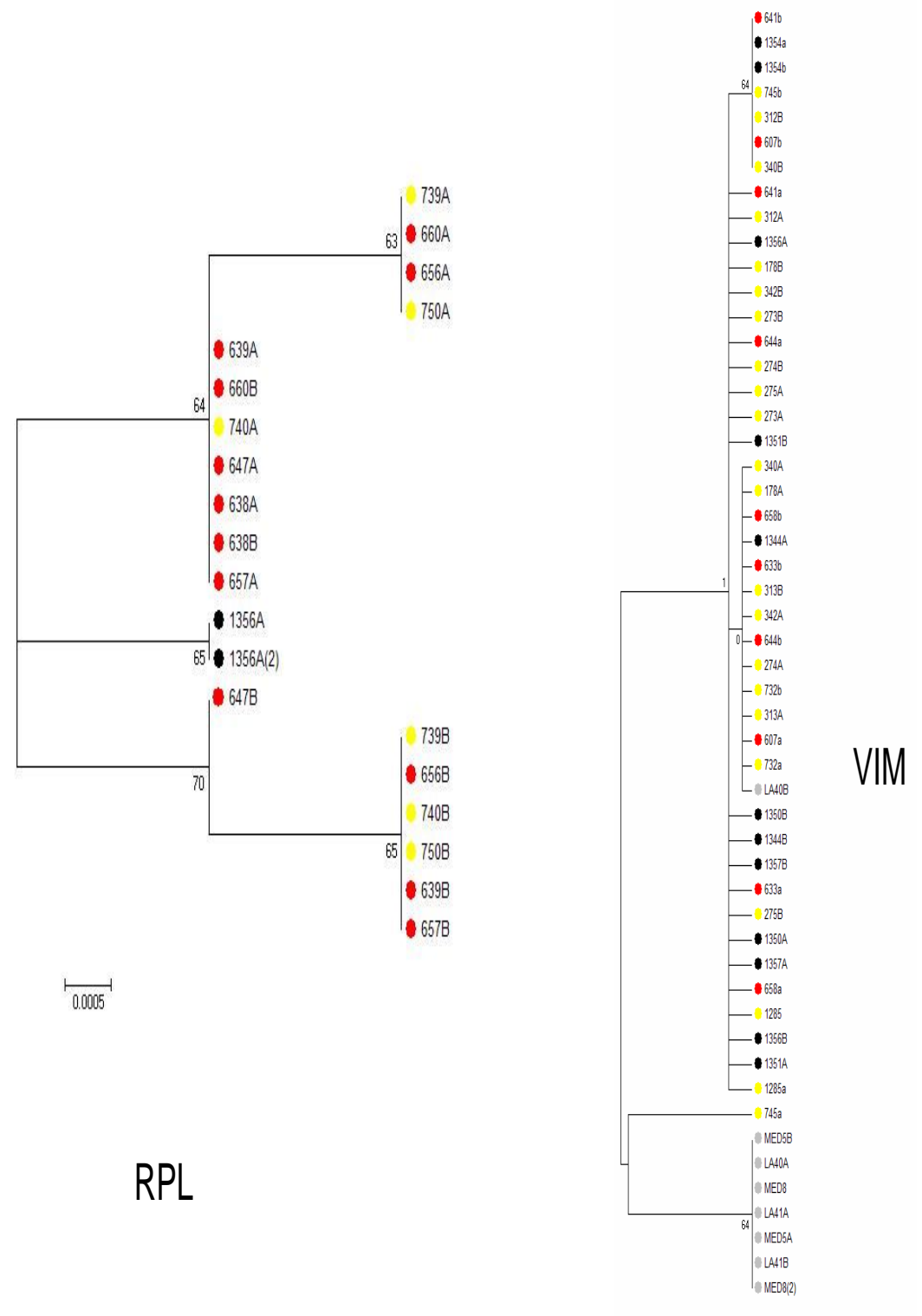

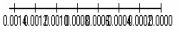

Figura 11 A: Árvore de Neighbour Joining para ao genes RPL; VIM, onde círculos vermelhos são amostras de Larus dominicanus provenientes de Santa Catarina, amarelo amostras de São Paulo, preto amostras da Península Antártica e cinza amostras de grupo externo. 


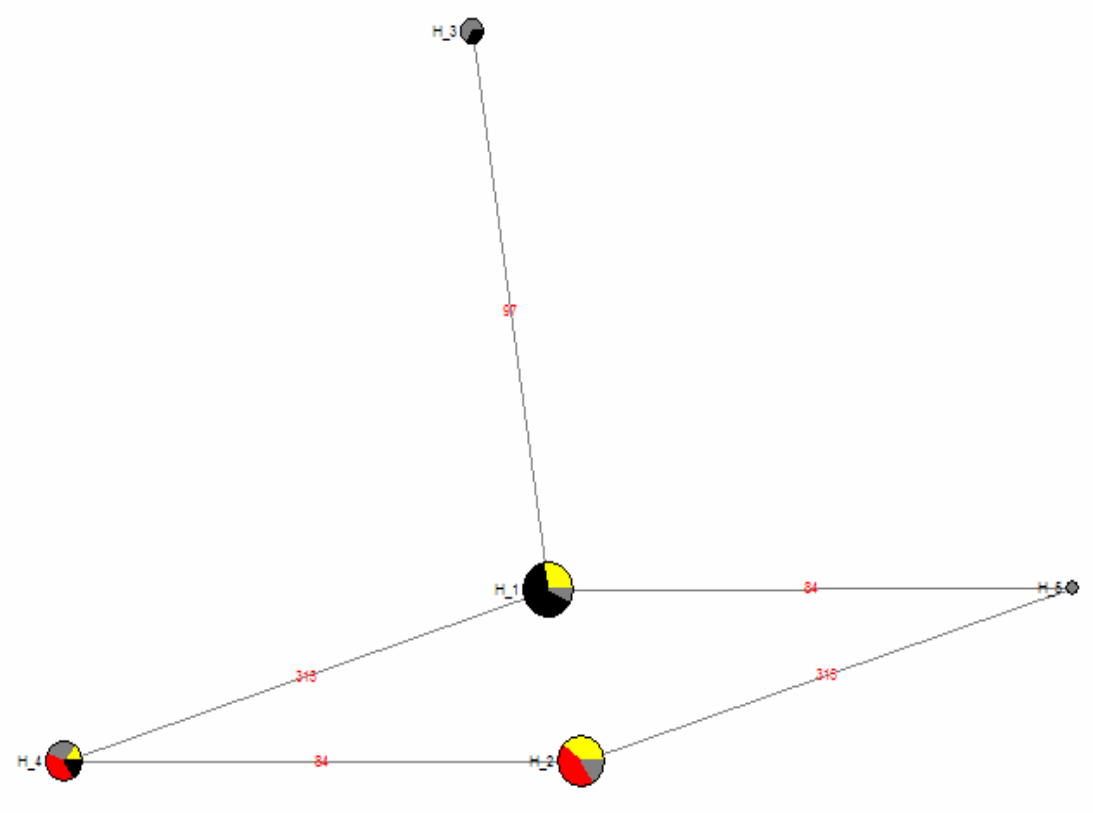

Figura 12.: Reduzido Median-joining network representando as relações filogenéticas entre os haplótipos do gene ACL, o tamanho do círculo é proporcional a frequência de cada haplótipo na amostra total. A cor vermelha representa indivíduos de Santa Catarina, amarelo de São Paulo, preto da Antártica e cinza corresponde ao grupo externo (Larus argentatus e Larus michahellis).

Tabela VII.: Análise de Variância Molecular (AMOVA) para o gene ACL incluindo as três macro-regiões da distribuição de Larus dominicanus analisadas neste estudo (São Paulo, Santa Catarina, Península Antártica).

\begin{tabular}{lcccc}
\hline Fontes de variação & d.f. & $\begin{array}{c}\text { Soma de } \\
\text { quadrado }\end{array}$ & $\begin{array}{c}\text { Componentes } \\
\text { de variação }\end{array}$ & $\begin{array}{c}\text { Porcentagem } \\
\text { de variação }\end{array}$ \\
\hline Entre populações & 2 & 2,433 & $0,09463 \mathrm{Va}$ & 13,75 \\
Dentro de populações & 27 & 7,300 & $0,02703 \mathrm{Vb}$ & 86,25 \\
\hline Total & 29 & 9,733 & 0,36500 & \\
\hline
\end{tabular}

Fst $=0,03592$ p=0,00196

Tabela VIII.: Fst por par de regiões amostradas para Larus dominicanus para o gene ACL (Hemimatriz inferior) e estimativa de Nm (hemimatriz superior). Valores significativos com $p<0,05$ estão indicados em negrito. NG significa valores negativos.

\begin{tabular}{l|lll}
\hline & Antartica & São Paulo & Santa Catarina \\
\hline Antartica & - & 0,804 & 0,304 \\
São Paulo & $\mathbf{0 , 2 3 7 1 5 *}$ & - & 19,99 \\
Santa Catarina & $\mathbf{0 , 4 5 0 5 9 *}$ & 0,01235 & - \\
\hline
\end{tabular}




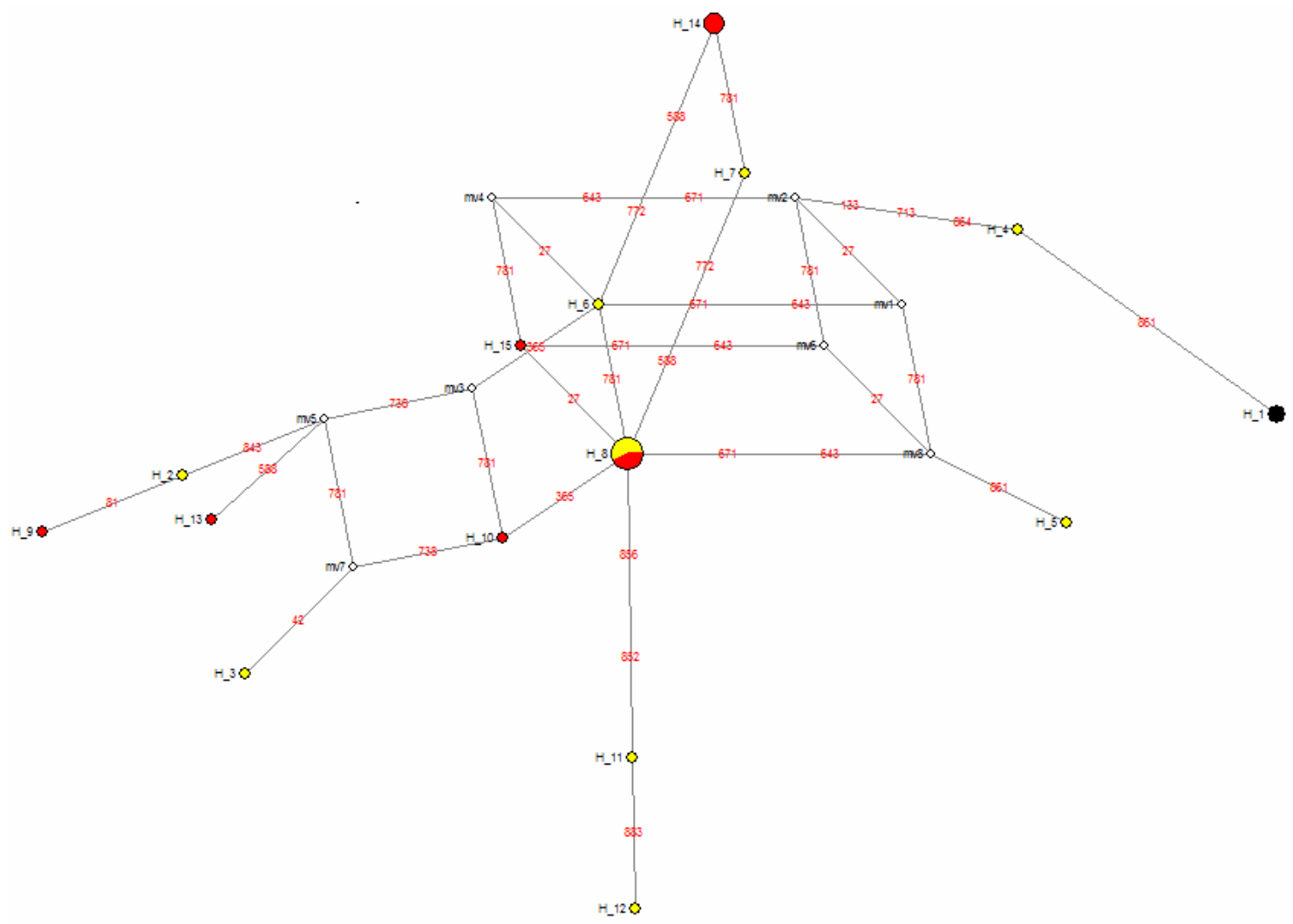

Figura 13.: Reduzido Median-joining network representando as relações filogenéticas entre os haplótipos do gene AK1, o tamanho do círculo é proporcional a frequência de cada haplótipo na amostra total. Os círculos abertos brancos representam haplótipos intermediários. A cor vermelha representa indivíduos de Santa Catarina, amarelo de São Paulo, preto da Antártica.

Tabela IX.: Análise de Variância Molecular (AMOVA) para o gene AK1 incluindo as três macro-regiões da distribuição de Larus dominicanus analisadas neste estudo (São Paulo, Santa Catarina, Península Antártica).

\begin{tabular}{lcccc}
\hline Fontes de variação & d.f. & $\begin{array}{c}\text { Soma de } \\
\text { quadrado }\end{array}$ & $\begin{array}{c}\text { Componentes } \\
\text { de variação }\end{array}$ & $\begin{array}{c}\text { Porcentagem } \\
\text { de variação }\end{array}$ \\
\hline Entre populações & 2 & 1,558 & $0,05200 \mathrm{Va}$ & 10,93 \\
Dentro de populações & 21 & 8,900 & $0,42381 \mathrm{Vb}$ & 89,07 \\
\hline Total & 23 & 10,458 & 0,45581 & \\
\hline
\end{tabular}

Fst $=0,10929 p=0,01173$

Tabela X.: Fst por par de regiões amostradas para Larus dominicanus para o gene AK1(Hemimatriz inferior) e estimativa de $\mathrm{Nm}$ (hemimatriz superior). Valores significativos com $p<0,05$ estão indicados em negrito.

\begin{tabular}{l|lll}
\hline & Antartica & São Paulo & Santa Catarina \\
\hline Antartica & - & 0,518 & 0,612 \\
São Paulo & $\mathbf{0 , 3 2 5 2 6}$ & - & 18,93 \\
Santa Catarina & $\mathbf{0 , 2 8 9 9 4}$ & 0,01303 & - \\
\hline
\end{tabular}




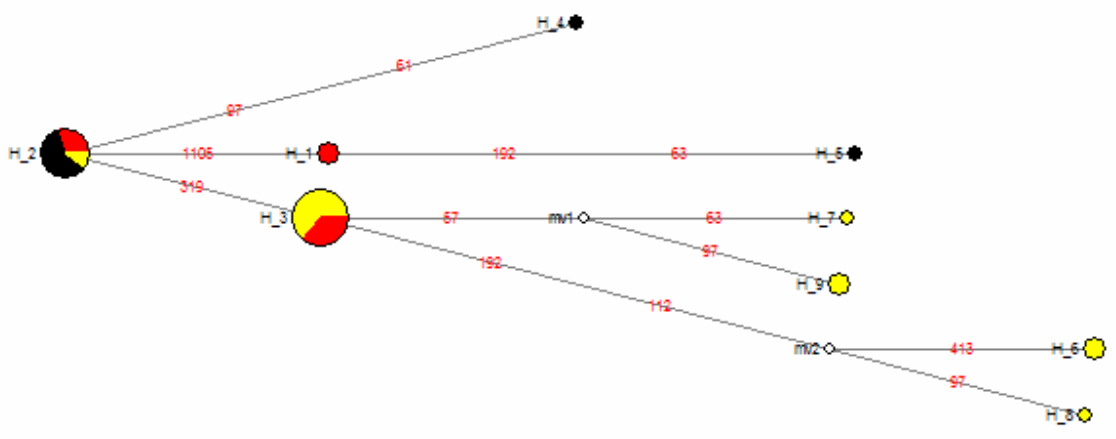

Figura 14.: Reduzido Median-joining network representando as relações filogenéticas entre os haplótipos do gene AXIN, o tamanho do círculo é proporcional a frequência de cada haplótipo na amostra total. Os círculos abertos brancos representam haplótipos intermediários. A cor vermelha representa indivíduos de Santa Catarina, amarelo de São Paulo, preto da Antártica.

Tabela XI.: Análise de Variância Molecular (AMOVA) para o gene AXIN incluindo as três macro-regiões da distribuição de Larus dominicanus analisadas neste estudo (São Paulo, Santa Catarina, Península Antártica).

\begin{tabular}{lcccc}
\hline Fontes de variação & d.f. & $\begin{array}{c}\text { Soma de } \\
\text { quadrado }\end{array}$ & $\begin{array}{c}\text { Componentes } \\
\text { de variação }\end{array}$ & $\begin{array}{c}\text { Porcentagem } \\
\text { de variação }\end{array}$ \\
\hline Entre populações & 2 & 2,562 & $0,08899 \mathrm{Va}$ & 21,88 \\
Dentro de populações & 31 & 9,850 & $0,31774 \mathrm{Vb}$ & 78,12 \\
\hline Total & 33 & 12,412 & 0,40673 & \\
\hline
\end{tabular}

Fst $=0,21878 \mathrm{p}=0,00293$

Tabela XII.: Fst por par de regiões para o gene AXIN(Hemimatriz inferior) e estimativa de $\mathrm{Nm}$ (hemimatriz superior). Valores significativos com $\mathrm{p}<0,05$ estão indicados em negrito.

\begin{tabular}{l|lll}
\hline & Antártica & São Paulo & Santa Catarina \\
\hline Antártica & - & 0,412 & 0,755 \\
São Paulo & $\mathbf{0 , 3 7 7 5 2}$ & - & 12,24 \\
Santa Catarina & $\mathbf{0 , 2 4 8 6 2}$ & 0,02001 & - \\
\hline
\end{tabular}




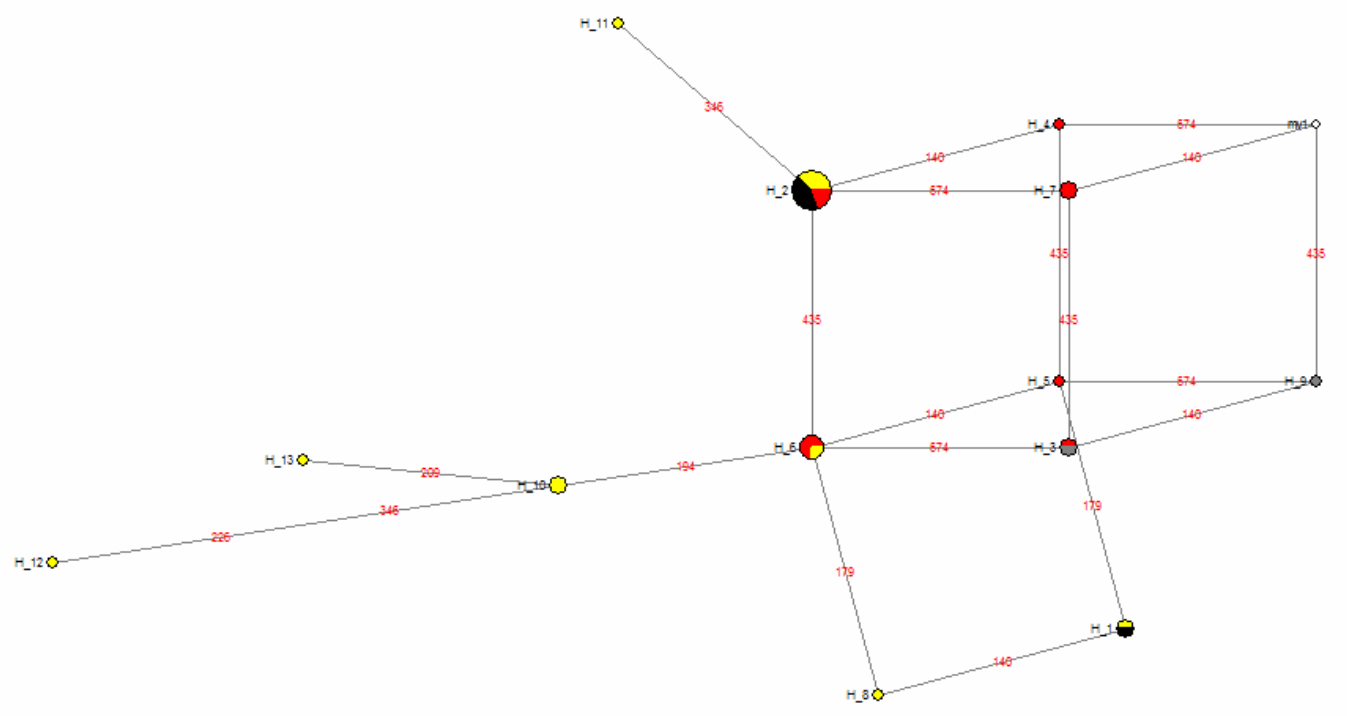

Figura 15.: Reduzido Median-joining network representando as relações filogenéticas entre os haplótipos do gene CEPU, o tamanho do círculo é proporcional a frequência de cada haplótipo na amostra total. Os círculos abertos brancos representam haplótipos intermediários. A cor vermelha representa indivíduos de Santa Catarina, amarelo de São Paulo, preto da Antártica e cinza corresponde ao grupo externo (Larus argentatus).

Tabela XIII.: Análise de Variância Molecular (AMOVA) para o gene CEPU incluindo as três macro-regiões da distribuição de Larus dominicanus analisadas neste estudo(São Paulo, Santa Catarina, Península Antártica)..

\begin{tabular}{lcccc}
\hline Fontes de variação & d.f. & $\begin{array}{c}\text { Soma de } \\
\text { quadrado }\end{array}$ & $\begin{array}{c}\text { Componentes } \\
\text { de variação }\end{array}$ & $\begin{array}{c}\text { Porcentagem } \\
\text { de variação }\end{array}$ \\
\hline Entre populações & 2 & 1,530 & $0,04240 \mathrm{Va}$ & 9,70 \\
Dentro de populações & 24 & 9,470 & $0,39457 \mathrm{~b}$ & 90,30 \\
\hline Total & 26 & 11,000 & 0,43697 & \\
\hline
\end{tabular}

Fst $=0,09703$ p $=0,03421$

Tabela XIV.: Fst por par de regiões amostradas de Larus dominicanus para o gene CEPU(Hemimatriz inferior) e estimativa de $\mathrm{Nm}$ (hemimatriz superior). Valores significativos com $\mathrm{p}<0,05$ estão indicados em negrito.

\begin{tabular}{l|lll}
\hline & Antártica & São Paulo & Santa Catarina \\
\hline Antártica & - & 1,765 & 0,852 \\
São Paulo & 0,12404 & - & 22,919 \\
Santa Catarina & $\mathbf{0 , 2 2 6 6 7}$ & 0,01079 & - \\
\hline
\end{tabular}




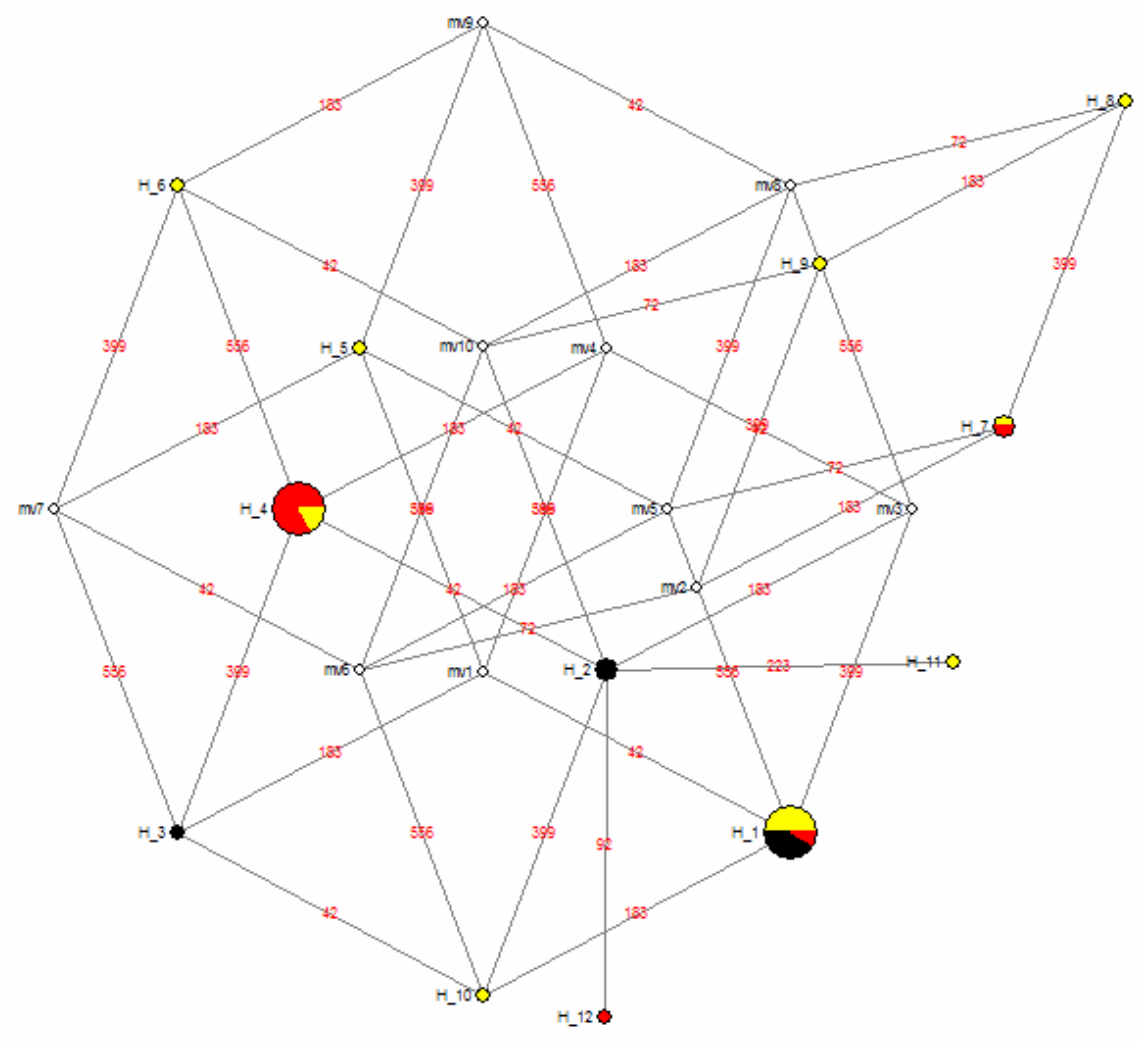

Figura 16.: Reduzido Median-joining network representando as relações filogenéticas entre os haplótipos do gene CRM, o tamanho do círculo é proporcional a frequência de cada haplótipo na amostra total. Os círculos abertos brancos representam haplótipos intermediários. A cor vermelha representa indivíduos de Santa Catarina, amarelo de São Paulo e preto da Antártica.

Tabela XV.: Analise de Variância Molecular (AMOVA) para o gene CRM incluindo as três macro-regiões da distribuição de Larus dominicanus analisadas neste estudo (São Paulo, Santa Catarina, Península Antártica).

\begin{tabular}{lcccc}
\hline Fontes de variação & d.f. & $\begin{array}{c}\text { Soma de } \\
\text { quadrado }\end{array}$ & $\begin{array}{c}\text { Componentes } \\
\text { de variação }\end{array}$ & $\begin{array}{c}\text { Porcentagem } \\
\text { de variação }\end{array}$ \\
\hline Entre populações & 2 & 3,010 & $0,10103 \mathrm{Va}$ & 23,64 \\
Dentro de populações & 33 & 10,768 & $0,32630 \mathrm{~b}$ & 76,36 \\
\hline Total & 35 & 13,778 & 0,42733 & \\
\hline
\end{tabular}

Fst $=0,23642 p=0,0000$

Tabela XVI.: Fst por par de regiões amostradas para Larus dominicanus para o gene CRM. (Hemimatriz inferior) e estimativa de $\mathrm{Nm}$ (hemimatriz superior). Valores significativos com $\mathrm{p}<0,05$ estão indicados em negrito.

\begin{tabular}{l|lll}
\hline & Antartica & São Paulo & Santa Catarina \\
\hline Antartica & - & 18,024 & 0,336 \\
São Paulo & 0,01368 & - & 0,841 \\
Santa Catarina & $\mathbf{0 , 4 2 6 2 0}$ & $\mathbf{0 , 2 2 8 9 5}$ & - \\
\hline
\end{tabular}




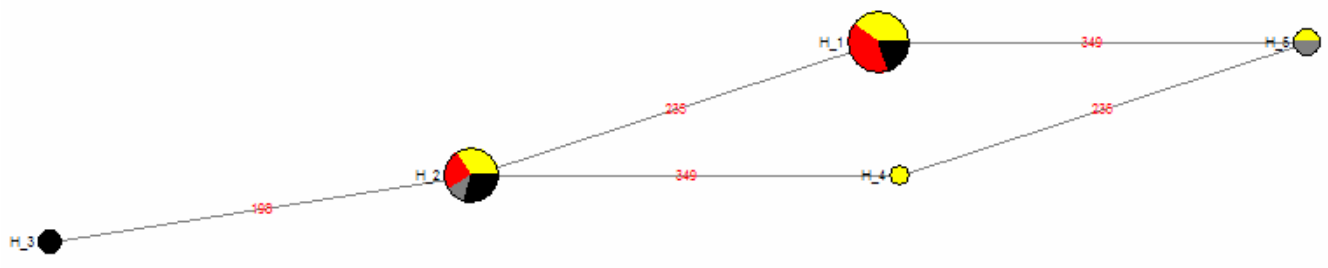

Figura 17.: Reduzido Median-joining network representando as relações filogenéticas entre os haplótipos do gene LRPP, o tamanho do círculo é proporcional a frequência de cada haplótipo na amostra total. Os círculos abertos brancos representam haplótipos intermediários. A cor vermelha representa indivíduos de Santa Catarina, amarelo de São Paulo, preto da Antártica e cinza corresponde ao grupo externo (Larus argentatus e Larus michahellis).

Tabela XVII.: Análise de Variância Molecular (AMOVA) para o gene LRPP incluindo as três macro-regiões da distribuição de Larus dominicanus analisadas neste estudo (São Paulo, Santa Catarina, Península Antártica).

\begin{tabular}{lcccc}
\hline Fontes de variação & d.f. & $\begin{array}{c}\text { Soma de } \\
\text { quadrado }\end{array}$ & $\begin{array}{c}\text { Componentes } \\
\text { de variação }\end{array}$ & $\begin{array}{c}\text { Porcentagem } \\
\text { de variação }\end{array}$ \\
\hline Entre populações & 2 & 0,571 & $-0,00321 \mathrm{Va}$ & $-0,98$ \\
Dentro de populações & 39 & 12,881 & $0,33028 \mathrm{~b}$ & 100,98 \\
\hline Total & 41 & 13,452 & 0,31708 & \\
\hline
\end{tabular}

Fst $=-0,0098$ p=0,49462

Tabela XVIII.: Fst por par de regiões amostradas para Larus dominicanus para o gene LRPP (Hemimatriz inferior) e estimativa de Nm (hemimatriz superior). NG significa valores negativos.

\begin{tabular}{l|lll}
\hline & Antártica & São Paulo & Santa Catarina \\
\hline Antártica & - & 32,008 & 36,193 \\
São Paulo & 0,00775 & - & NG \\
Santa Catarina & 0,00686 & $-0,04013$ & - \\
\hline
\end{tabular}




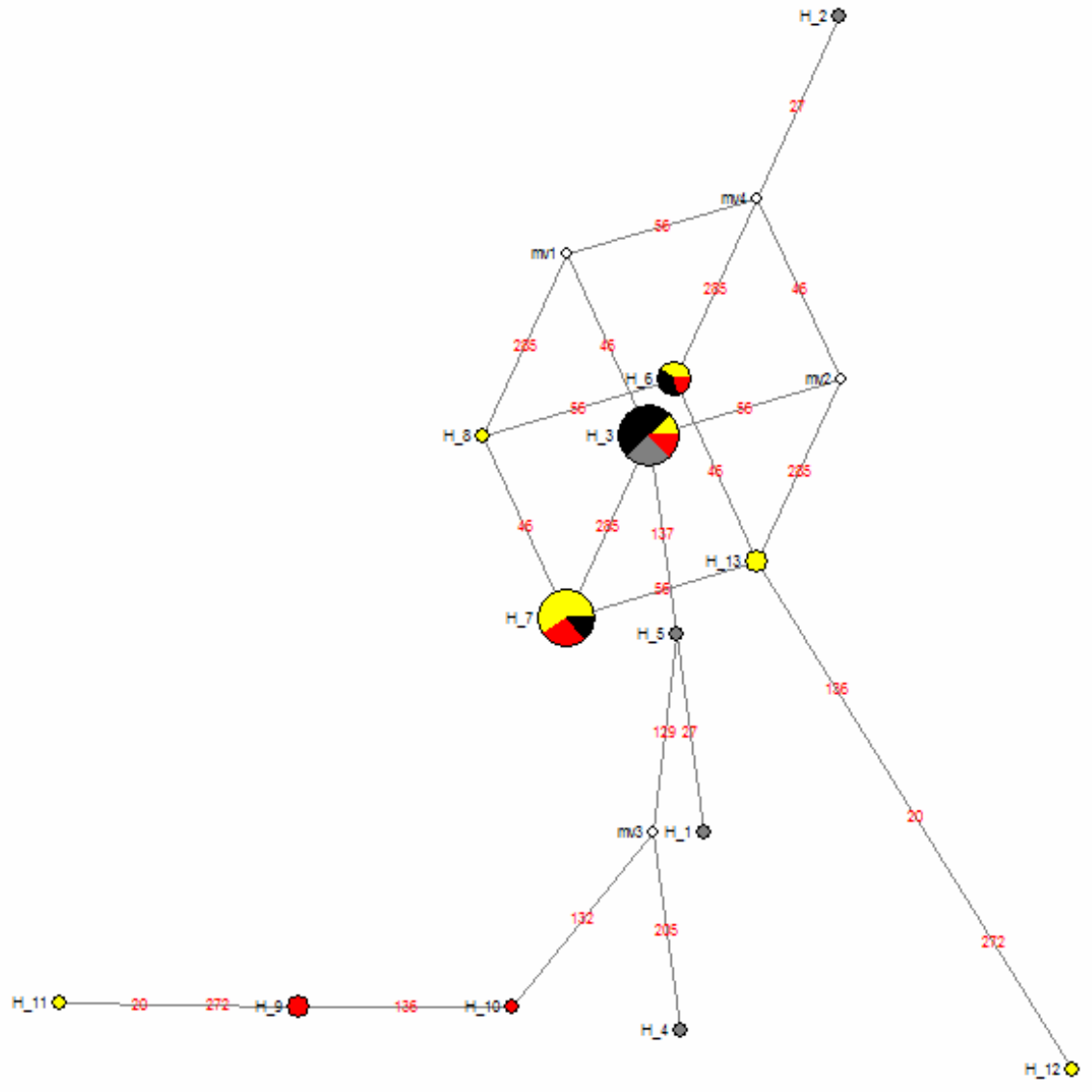

Figura 18.: Reduzido Median-joining network representando as relações filogenéticas entre os haplótipos do gene MPL, o tamanho do círculo é proporcional a frequência de cada haplótipo na amostra total. Os círculos abertos brancos representam haplótipos intermediários. A cor vermelha representa indivíduos de Santa Catarina, amarelo de São Paulo, preto da Antártica e cinza corresponde ao grupo externo (Larus argentatus e Larus michahellis).

Tabela XIX.: Análise de Variância Molecular (AMOVA) para o gene MPL incluindo as três macro-regiões da distribuição de Larus dominicanus analisadas neste estudo (São Paulo, Santa Catarina, Península Antártica)..

\begin{tabular}{lcccc}
\hline Fontes de variação & d.f. & $\begin{array}{c}\text { Soma de } \\
\text { quadrado }\end{array}$ & $\begin{array}{c}\text { Componentes } \\
\text { de variação }\end{array}$ & $\begin{array}{c}\text { Porcentagem } \\
\text { de variação }\end{array}$ \\
\hline Entre populações & 2 & 1,892 & $0,04601 \mathrm{Va}$ & 11,55 \\
Dentro de populações & 37 & 13.033 & $0,35225 \mathrm{Vb}$ & 88,45 \\
\hline Total & 39 & 14,925 & 0,39827 & \\
\hline
\end{tabular}

Fst $=-\mathbf{0 , 0 0 9 8} p=0,49462$

Tabela XX.: Fst por par de regiões amostradas de Larus dominicanus para o gene MPL(Hemimatriz inferior) e estimativa de Nm (hemimatriz superior). Valor significativo com $\mathrm{p}<0,05$ estão indicados em negrito. NG significa valores negativos.

\begin{tabular}{c|ccc}
\hline & Antártica & São Paulo & Santa Catarina \\
\hline Antártica & - & 0,947 & 1,643 \\
São Paulo & $\mathbf{0 , 2 0 8 7 9}$ & - & NG \\
Santa Catarina & 0,13203 & $-0,02011$ & - \\
\hline
\end{tabular}




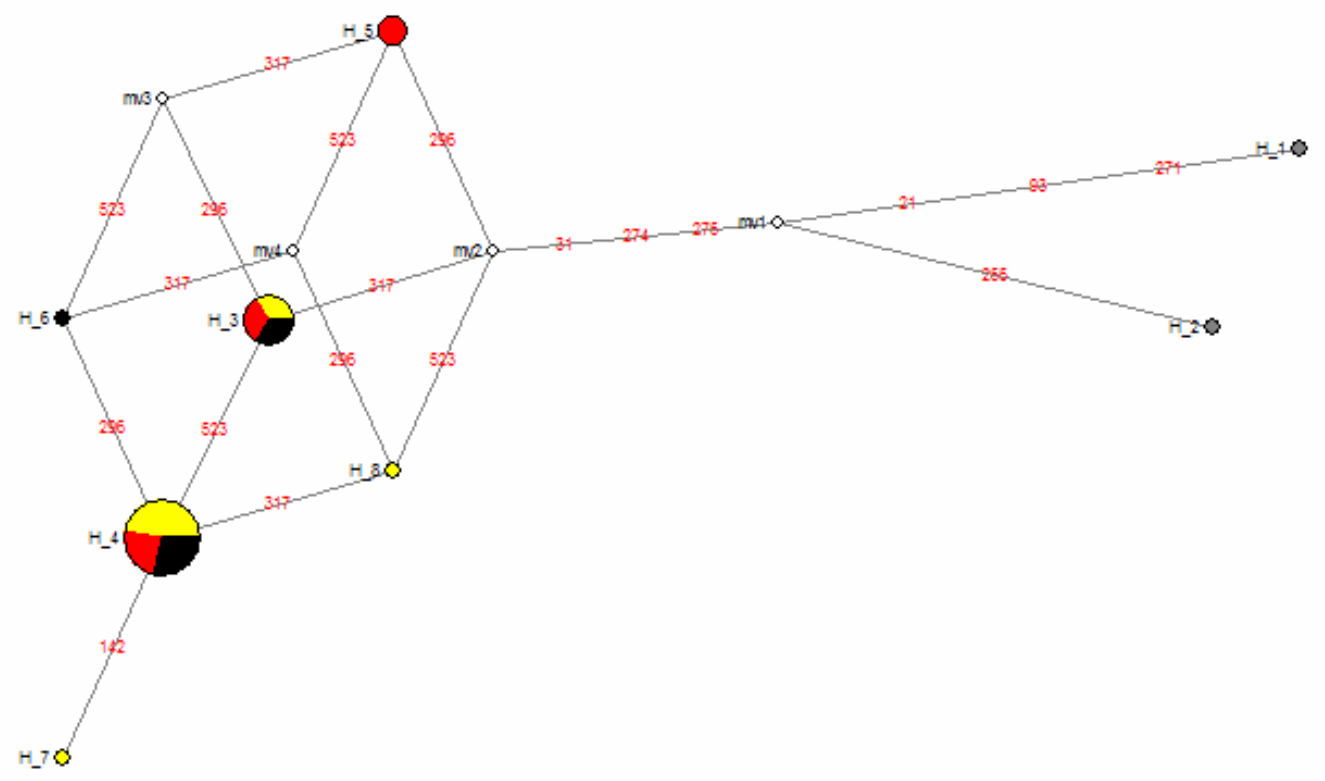

Figura 19.: Reduzido Median-joining network representando as relações filogenéticas entre os haplótipos do gene ODC, o tamanho do círculo é proporcional a frequência de cada haplótipo na amostra total. Os círculos abertos brancos representam haplótipos intermediários. A cor vermelha representa indivíduos de Santa Catarina, amarelo de São Paulo, preto da Antártica e cinza corresponde ao grupo externo (Larus ridibundus).

Tabela XXI.: Análise de Variância Molecular (AMOVA) para o gene ODC incluindo as três macro-regiões da distribuição de Larus dominicanus analisadas neste estudo (São Paulo, Santa Catarina, Península Antártica).

\begin{tabular}{lcccc}
\hline Fontes de variação & d.f. & $\begin{array}{c}\text { Soma de } \\
\text { quadrado }\end{array}$ & $\begin{array}{c}\text { Componentes } \\
\text { de variação }\end{array}$ & $\begin{array}{c}\text { Porcentagem } \\
\text { de variação }\end{array}$ \\
\hline Entre populações & 2 & 0,645 & $0,00181 \mathrm{Va}$ & 0,60 \\
Dentro de populações & 33 & 9,938 & $0,30115 \mathrm{Vb}$ & 99,40 \\
\hline Total & 35 & 10,583 & 0,30296 & \\
\hline
\end{tabular}

Fst $=-0,0596 p=0,34409$

Tabela XXII.: Fst por par de regiões amostradas para Larus dominicanus para o gene ODC (Hemimatriz inferior) e estimativa de Nm (hemimatriz superior). NG significa valores negativos.

\begin{tabular}{l|lll}
\hline & Antartica & São Paulo & Santa Catarina \\
\hline Antartica & - & NG & NG \\
São Paulo & $-0,05471$ & - & NG \\
Santa Catarina & $-0,00758$ & $-0,05568$ & - \\
\hline
\end{tabular}




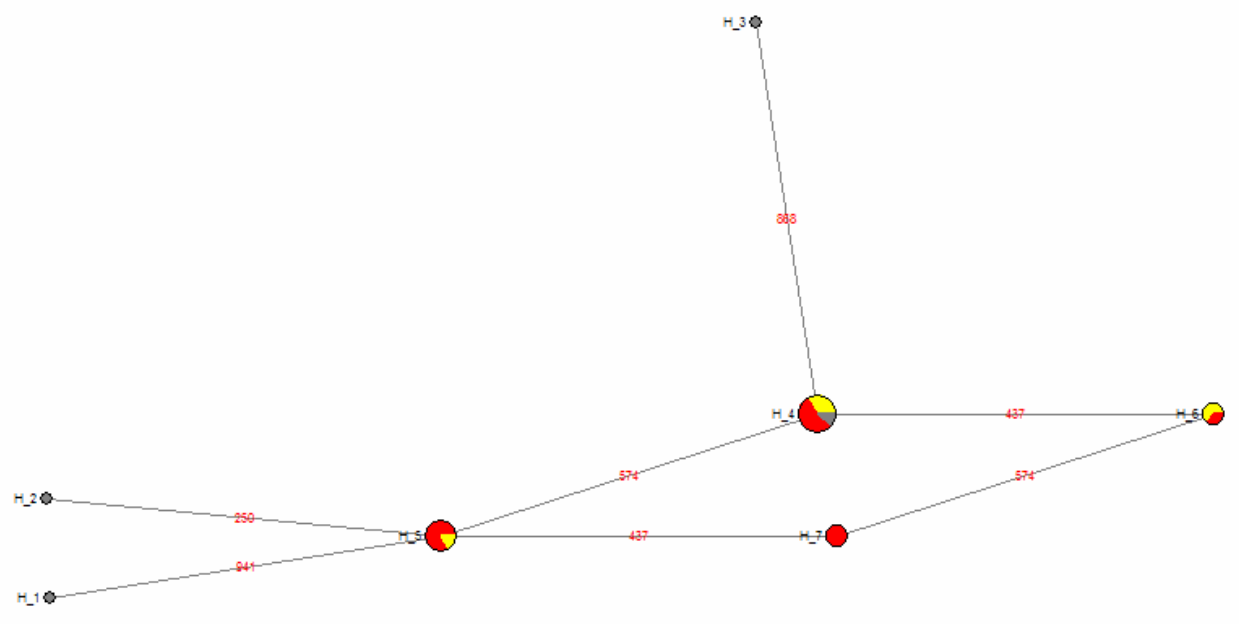

Figura 20.: Reduzido Median-joining network representando as relações filogenéticas entre os haplótipos do gene RAG1, o tamanho do círculo é proporcional a frequência de cada haplótipo na amostra total. Os círculos abertos brancos representam haplótipos intermediários. A cor vermelha representa indivíduos de Santa Catarina, amarelo de São Paulo, preto da Antártica e cinza corresponde ao grupo externo (Larus fuscus e Larus marinus).

Tabela XXIII.: Análise de Variância Molecular (AMOVA) para o gene RAG1 incluindo as três macro-regiões da distribuição de Larus dominicanus analisadas neste estudo (São Paulo, Santa Catarina, Península Antártica)..

\begin{tabular}{lcccc}
\hline Fontes de variação & d.f. & $\begin{array}{c}\text { Soma de } \\
\text { quadrado }\end{array}$ & $\begin{array}{c}\text { Componentes } \\
\text { de variação }\end{array}$ & $\begin{array}{c}\text { Porcentagem } \\
\text { de variação }\end{array}$ \\
\hline Entre populações & 1 & 0,360 & $-0,00145 \mathrm{Va}$ & $-0,39$ \\
Dentro de populações & 18 & 6,690 & $0,37169 \mathrm{Vb}$ & 100,39 \\
\hline Total & 19 & 7,050 & 0,37024 & \\
\hline
\end{tabular}

Fst $=-0,00391 p=0,43304$

Tabela XXIV.: Fst por par de regiões amostradas para Larus dominicanus para o gene RAG1. (Hemimatriz inferior) e estimativa de Nm (hemimatriz superior). NG significa valores negativos.

\begin{tabular}{l|lll}
\hline & Antártica & São Paulo & Santa Catarina \\
\hline Antártica & - & NG & NG \\
São Paulo & 0,00000 & - & NG \\
Santa Catarina & $-0,00391$ & 0,00000 & - \\
\hline
\end{tabular}




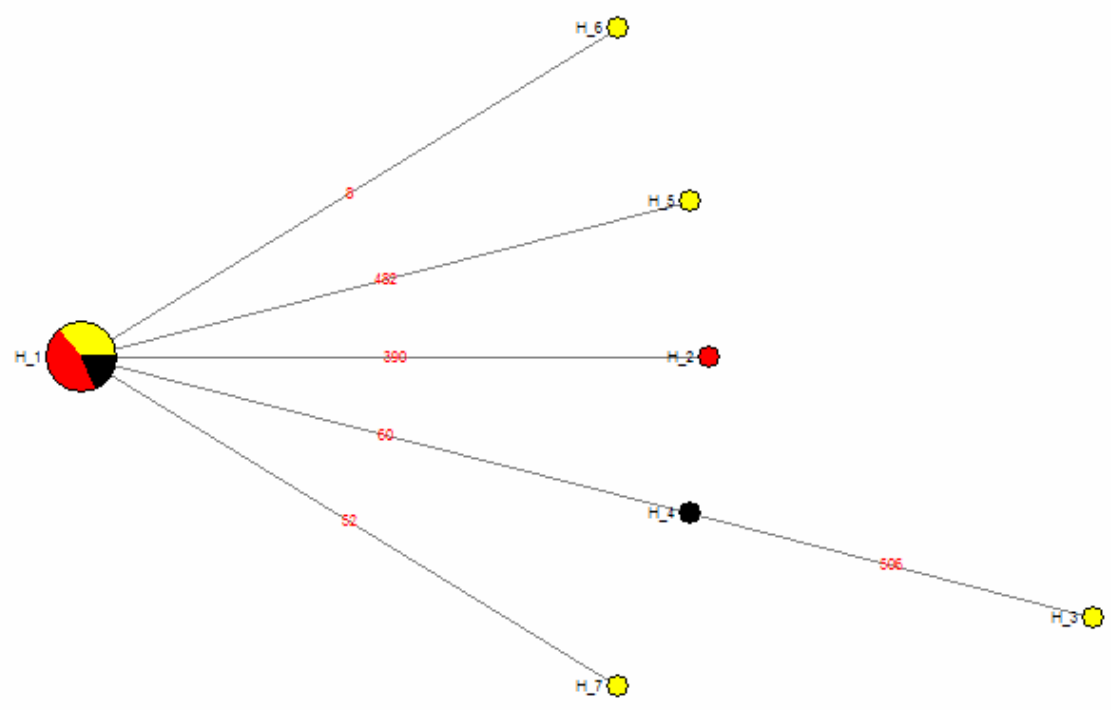

Figura 21.: Reduzido Median-joining network representando as relações filogenéticas entre os haplótipos do gene RGS, o tamanho do círculo é proporcional a frequência de cada haplótipo na amostra total. Os círculos abertos brancos representam haplótipos intermediários. A cor vermelha representa indivíduos de Santa Catarina, amarelo de São Paulo e preto da Antártica.

Tabela XXV.: Análise de Variância Molecular (AMOVA) para o gene RGS incluindo as três macro-regiões da distribuição de Larus dominicanus analisadas neste estudo(São Paulo, Santa Catarina, Península Antártica).

\begin{tabular}{lcccc}
\hline Fontes de variação & d.f. & $\begin{array}{c}\text { Soma de } \\
\text { quadrado }\end{array}$ & $\begin{array}{c}\text { Componentes } \\
\text { de variação }\end{array}$ & $\begin{array}{c}\text { Porcentagem } \\
\text { de variação }\end{array}$ \\
\hline Entre populações & 2 & 1,029 & $0,02272 \mathrm{Va}$ & 7,65 \\
Dentro de populações & 31 & 8,500 & $0,27419 \mathrm{Vb}$ & 92,35 \\
\hline Total & 33 & 9,529 & 0,29691 & \\
\hline
\end{tabular}

Fst $=-\mathbf{0 , 0 7 6 5 1} p=0,05083$

Tabela XXVI.: Fst por par de regiões amostradas para Larus dominicanus para o gene RGS. (Hemimatriz inferior) e estimativa de Nm (hemimatriz superior). NG significa valores negativos.

\begin{tabular}{l|lll}
\hline & Antartica & São Paulo & Santa Catarina \\
\hline Antartica & - & 7,628 & 2,571 \\
São Paulo & 0,03173 & - & 2,278 \\
Santa Catarina & 0,08861 & $\mathbf{0 , 0 9 8 8 9}$ & - \\
\hline
\end{tabular}




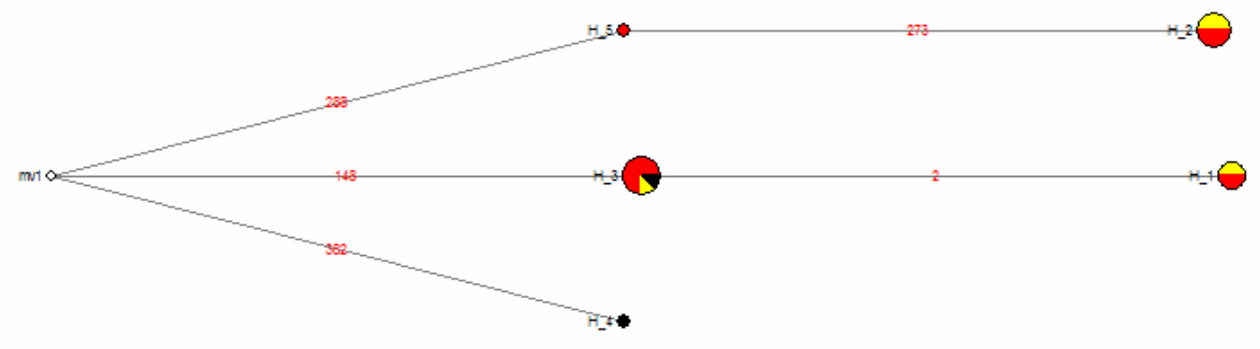

Figura 22.: Reduzido Median-joining network representando as relações filogenéticas entre os haplótipos do gene RPL7A, o tamanho do círculo é proporcional a frequência de cada haplótipo na amostra total. Os círculos abertos brancos representam haplótipos intermediários. A cor vermelha representa indivíduos de Santa Catarina, amarelo de São Paulo e preto da Antártica.

Tabela XXVII.: Analise de Variância Molecular (AMOVA) para o gene RPL7A incluindo as três macro-regiões da distribuição de Larus dominicanus analisadas neste estudo (São Paulo, Santa Catarina, Península Antártica).

\begin{tabular}{lcccc}
\hline Fontes de variação & d.f. & $\begin{array}{c}\text { Soma de } \\
\text { quadrado }\end{array}$ & $\begin{array}{c}\text { Componentes } \\
\text { de variação }\end{array}$ & $\begin{array}{c}\text { Porcentagem } \\
\text { de variação }\end{array}$ \\
\hline Entre populações & 2 & 0,800 & $0,00599 \mathrm{Va}$ & 1,60 \\
Dentro de populações & 17 & 6,250 & $0,36765 \mathrm{Vb}$ & 98,40 \\
\hline Total & 19 & 7.050 & 0,37364 & \\
\hline
\end{tabular}

Fst $=0,01603 \quad p=0,34506$

Tabela XXVIII.: Fst por par de regiões amostradas para Larus dominicanus para o gene RPL7A. (Hemimatriz inferior) e estimativa de Nm (hemimatriz superior). NG significa valores negativos.

\begin{tabular}{l|lll}
\hline & Antártica & São Paulo & Santa Catarina \\
\hline Antártica & - & 1,909 & NG \\
São Paulo & 0,11579 & - & 12,544 \\
Santa Catarina & $-0,05912$ & 0,01954 & - \\
\hline
\end{tabular}




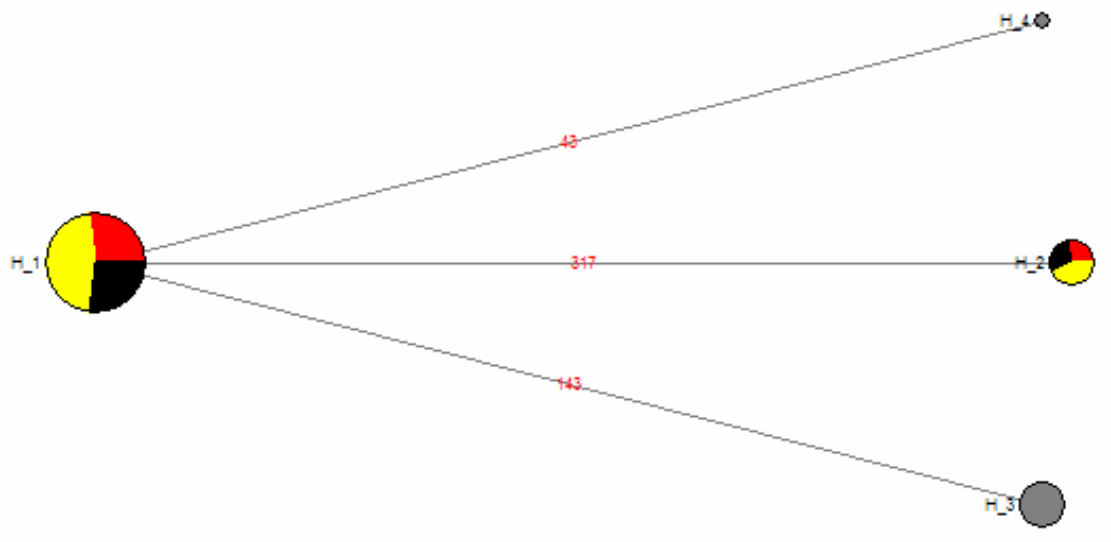

Figura 23.: Reduzido Median-joining network representando as relações filogenéticas entre os haplótipos do gene VIM, o tamanho do círculo é proporcional a frequência de cada haplótipo na amostra total. Os círculos abertos brancos representam haplótipos intermediários. A cor vermelha representa indivíduos de Santa Catarina, amarelo de São Paulo, preto da Antártica e cinza corresponde ao grupo externo (Larus argentatus e Larus michahellis).

Tabela XXIX.: Analise de Variância Molecular (AMOVA) para o gene VIM incluindo as três macro-regiões da distribuição de Larus dominicanus analisadas neste estudo (São Paulo, Santa Catarina, Península Antártica).

\begin{tabular}{lcccc}
\hline Fontes de variação & d.f. & $\begin{array}{c}\text { Soma de } \\
\text { quadrado }\end{array}$ & $\begin{array}{c}\text { Componentes } \\
\text { de variação }\end{array}$ & $\begin{array}{c}\text { Porcentagem } \\
\text { de variação }\end{array}$ \\
\hline Entre populações & 2 & 0,003 & $-0,01001 \mathrm{Va}$ & $-7,50$ \\
Dentro de populações & 41 & 5,883 & $0,14350 \mathrm{Vb}$ & 107,50 \\
\hline Total & 43 & 5,886 & 0,13346 & \\
\hline
\end{tabular}

Fst $=0,01603 p=0,34506$

Tabela XXX.: Fst por par de regiões amostradas para Larus dominicanus para o gene VIM (Hemimatriz inferior) e estimativa de Nm (hemimatriz superior). NG significa valores negativos.

\begin{tabular}{l|lll}
\hline & Antártica & São Paulo & Santa Catarina \\
\hline Antártica & - & NG & NG \\
São Paulo & $-0,07030$ & - & NG \\
Santa Catarina & $-0,09091$ & $-0,07030$ & - \\
\hline
\end{tabular}




\section{DISCUSSÃO}

Estudos populacionais utilizando diversos marcadores nucleares são recentes e escassos, devido à falta de marcadores universais e à dificuldade de determinar os haplótipos (ZHANG \& HEWITT, 2003). O projeto genoma de várias espécies tem auxiliado no desenvolvimento de novos marcadores para organismos não modelos. Este tipo de abordagem de usar sequências disponíveis em bancos públicos para o desenvolvimento de marcadores vem sendo utilizada por alguns pesquisadores nos últimos anos (PALUMBI \& BAKER, 1994; BERREBI et al., 2006; DOLMAN \& PHILLIPS, 2004). Entretanto, os marcadores nucleares frequentemente falham na amplificação de grupos taxonômicos distantes ou amplificam sequências que não são sustentáveis para estudos intraespecíficos (ZHANG \& HEWITT, 2003). Em nosso estudo conseguimos boas amplificações em Larus dominicanus com marcadores nucleares desenvolvidos para espécies de Galliformes (Gallus gallus, Alectoris sp). A nossa eficiência de procura de novos marcadores em gaivotas foi menor que $40 \%$.

BERREBI et al. (2006) usando a mesma abordagem para uma espécie de peixe Opsariichthys bidens teve um sucesso de $21 \%$ no desenvolvimento marcadores nucleares (24 primers testados e somente 5 apresentaram padrões polimórficos). Dessa forma, a procura e o desenvolvimento de marcadores requer um grande investimento de tempo e dinheiro.

Os marcadores nucleares utilizados nesse trabalho em Larus dominicanus mostraram maior diversidade genética em relação ao DNA mitocondrial. Todos os treze genes amplificados apresentaram sítios polimórficos (mínimo de 3 sítios e o máximo de 23 sítios), apresentando diversidade haplotípica nuclear cerca de 2 vezes maior que a diversidade encontrada no DNA mitocondrial. De acordo com Zhang \& Hewitt (2003) o polimorfismo $(\pi)$ existente no genoma nuclear de organismos eucariotas é geralmente 
pequeno não sendo maior que 1 a $2 \%$ em muitos casos. Nossos dados apresentam uma quantidade de divergência par a par dentro do esperado para organismos eucariotas, variando de 1,1 a 4,8\%. DOLMAN e MORITZ (2007) ao compararem a divergência de múltiplos locus nucleares com resultados de locus mitocondriais para Carlia rubrigularis (lagartos) observaram que a diversidade média dos locus nucleares era duas vezes menor que a dos locus mitocondriais. Resultado oposto do que encontramos para Larus dominicanus.

A grande diversidade observada em múltiplos marcadores nucleares em Larus dominicanus indicaram que o processo que reduziu a diversidade genética no genoma mitocondrial pode não ser resultado de eventos demográficos. Considerando que eventos demográficos marcariam tanto o genoma mitocondrial como o genoma nuclear. Assim, se a baixa diversidade genética observada em L. dominicanus fosse resultado de eventos demográficos, como gargalos populacionais ou recente colonização seguidos de expansão, esperavamos encontrar desvio da neutralidade. Entretanto, os testes de neutralidade do D de Tajima e Fu \& $\mathrm{Li}\left(\mathrm{F}^{*} \mathrm{D}^{*}\right.$ ) não foram significativos para nenhum dos loci analisados. Dessa forma, estes testes não indicam que L. dominicanus tenham passado por eventos de seleção balanceadora ou apresente estrutura populacional (D>0) ou expansão populacional $(\mathrm{D}<0)$.

Além disso, não há um padrão na direção dos resultados dos testes de neutralidade entre os loci amostrados, cada locus segue uma direção, alguns mostram resultados positivos e outros mostram resultados negativos. Assim podemos afirmar que para os marcadores nucleares as população de Larus dominicanus amostradas, na costa brasileira e na Península Antártica, estão sob evolução neutra sem ter sinal de expansão populacional. O que seria esperado após um evento de gargalo populacional ou recente 
colonização, em uma espécie de ampla distribuição geográfica e baixa variabilidade no DNA mitocondrial.

Assim, como poderíamos explicar a baixa variabilidade no DNA mitocondrial de Larus dominicanus? Quais os fatores evolutivos moldaram a variabilidade genética desse grupo? Tentando responder essas questões foram realizadas as análises de árvores de Neighbour Joining, apesar de não representarem a verdadeira árvore das populações por não levar em consideração todas as conexões possíveis entre os haplótipos. Porém, este tipo de abordagem permite vizualizar a relação entre os haplótipos e suas localidades geográficas. Entretanto, as árvores de Neighbor Joining geradas para loci analisados não apresentaram correlação clara e forte entre nenhum clado de haplótipos e/ou em relação as localizações geográficas. Genealogias confusas com baixos "bootstraps" podem ser resultados de recente divergência e incompleta separação de linhagens ou fluxo gênico entre localidades (PASB $\varnothing \mathrm{LL}$ et al., 2004). Porém, é importante notar que os grupos externos utilizados nas análises filogenéticas quase sempre apresentaram haplótipos compartilhados ou com relação muito próxima com os haplótipos de Larus dominicanus. Diferentes genes nucleares não ligados provêm independentes estimativas de árvores (MOORE, 1995). Como nossos 13 loci analisados apresentam um mesmo padrão de não estrutura entre os clados, podemos inferir que Larus dominicanus realmente tenha um origem recente, resultando em uma não completa separação de linhagens. Na ausência de hibridização, a deriva nos locus seria inevitável e eventualmente todos os loci neutros dentro de uma espécie irão torna-se monofiléticos com o passar do tempo (NEI, 1987; PALUMBI et al., 2001).

Os grupos externos utilizados nesse trabalho Larus argentatus, Larus atriccila, Larus michahellis, Larus marinus, Larus ridibundus e Larus fuscus fazem parte do complexo argentatus-fuscus que ocorre no hemisfério norte (CROCHET et al., 2002). 
Esse complexo de espécies apresenta frequente hibridização entre espécies bem estabelecidas, mas que ocorrem em simpatria (CROCHET et al., 2002). Entretanto, Larus dominicanus é uma espécie que ocorre somente no hemisfério sul, sendo portanto isolada geograficamente desse complexo de espécie. Filogenia molecular recente para as gaivotas de cabeça branca indicam que este grupo é um grupo monofilético (CROCHET et al., 2000). Porém, as relações inter-específicas dentro desse grupo não são muito claras. De acordo com CROCHET et al. (2002), Larus dominicanus foi considerado grupo irmão do clado argentatus-fuscus, porém sua posição em relação a todos os membros do clado foi pobremente suportado e não favorecido por todas as análises. LIEBERS et al. (2004) observou que Larus dominicanus compartilha haplótipos da região controle com espécies do complexo argentatus-fuscus, concluindo que L. dominicanus teria surgido através de colonização de longa distância pela espécie Larus fuscus graellsii, após essa ter se divergido dentro do complexo argentatus.

Tanto CROCHET et al. (2002) como LIEBERS et al. (2004) encontraram grande número de haplótipos mitocondriais compartilhados entre as espécies do complexo argentatus- fuscus. Este resultado poderia ser devido à recente divergência entre esses grupos ou fluxo gênico (introgressão). Porém, ambos os autores acreditam que o compartilhamento de haplótipos mitocondriais seria devido à introgressão entre as espécies e não a manutenção de linhagens ancestrais. CROCHET et al. (2002) afirma que para esse compartilhamento de haplótipos observado no DNA mitocondrial ser devido à manutenção de linhagens ancestrais, o tamanho efetivo da população teria que ser muito grande, não sendo um valor realístico. Os dados do presente estudo com loci nucleares também indicaram um compartilhamento de haplótipos, considerando os resultados obtidos por CROCHET et al. (2002) como LIEBERS et al. (2004) para os dados mitocondriais não nos surpreenderam os resultados encontrados nas genealogias 
nucleares. Levando-se em conta a diferença do tamanho efetivo entre esses marcadores e o tempo de coalescência de suas linhagens, que é quatro vezes maior nos genes nucleares.

Porém, resta saber se esse compartilhamento é devido à recente divergência e consequentemente incompleta separação de linhagens ou introgressão entre a espécie $L$. dominicanus e o complexo fuscus-argentatus. De acordo com LIEBERS et al. (2004) o tempo de divergência estimado entre L. cachinnans e Larus argentatus, considerando uma taxa mutacional de 1,6\% myr para o citocromo b, é de 380.000 anos (CI 10.200602.000). Se L. dominicanus realmente tiver divergido de Larus fuscus graellsii que faz parte do complexo argentatus-fuscus, o tempo de divergência entre esses grupos deve ser próximo da data acima estimada para L. cachinnans e Larus argentatus. O que significaria realmente uma divergência recente entre esses grupos.

Quanto à variabilidade intraespecífica as Análises de Variância Molecular indicaram que grande parte da variação encontra-se dentro das populações. Entretanto para 5 dos loci analisados (ACl, AK1, AXIN, CEPU, CRM) observamos resultado significativos de Fst, indicando uma pequena estrutura genética, principalmente entre a costa brasileira e a Península Antártica. Os demais loci analizados não apresentaram diferenciação significativa. Na ausência de seleção uma taxa de migração de 0,5 por geração seria o suficiente para homogenizar as populações. As estimativas de fluxo gênico baseado no Fst mostraram que há um intenso fluxo entre as regiões amostradas o que corrobora os dados de baixa diferenciação observada no loci nucleares e a não associação entre a relação dos haplótipos e suas distribuições geográficas. Entretanto, como os grupos externos compartilham haplótipos com L. dominicanus, indicando possível divergência recente do grupo é esperado que as populações de L. dominicanus não apresentem diferenciação com os marcadores nucleares. As análises de variância 
molecular foram significativas para alguns loci porque são realizadas com base na frequência dos haplótipos e não a relação filogenética entre eles.

As redes de haplótipos mostram todas as possíveis relações entre os mesmo. A rede gerada para os genes AXIN, RGS, RPL7A e VIM apresentam uma forma similar, um haplótipo mais abundante e outros derivados, sendo que o gene RGS é ligado por um haplótipo ancestral ou não amostrado. Porém os demais genes ACl, AK1, CRM, CEPU, ODC, RAG1, LRPP, MPL apresentam rede de haplótipos completamente reticulada. De acordo com ZHANG e HEWITT (2003) relações reticuladas podem ser produzidas por recombinação, por mutações paralelas e por recorrente mutações. $\mathrm{O}$ teste" four-gamete" demonstrou que há indícios de recombinação nos genes AK1, AXIN, CEPU, CRM, LRPP, MPL, ODC e RAG1, sendo que o Rm (mínimo evento de recombinação) variou de 1 a 5 (Tabela II), mas os genes ACL, RGS, RPL e VIM não apresentam sinais de recombinação.

Assim, podemos concluir que Larus dominicanus apresenta grande diversidade genética através dos marcadores nucleares, sendo essa extremamente superior a encontrada no DNA mitocondrial. Nas análises de um conjunto de indivíduos de toda a distribuição dessa espécie notamos que não há sinal de expansão populacional em nenhum dos 13 loci nucleares analisados. Nossos dados nos levam a inferir que essa espécie pode ter passado por um ou mais eventos de seleção no DNA mitocondrial que levou a uma redução drástica da variabilidade genética do grupo. 


\section{CAPITULO V}

\section{ESTUDOS POPULACIONAIS DE LARUS DOMINICANUS BASEADOS EM ANÁLISES DE LOCUS NUCLEARES ( $\beta$-FIBRINOGÊNIO)}

\section{INTRODUÇÃO}

O conhecimento sobre a história e os processos evolutivos que moldaram a diversidade das aves marinhas, bem como quais são as barreiras físicas e não físicas, para o fluxo gênico desse grupo continuam sendo um grande enigma (STEEVES et al., 2005b). Como o grupo é composto por espécies que apresentam ampla distribuição geográfica, alta capacidade de locomoção e que barreiras para dispersão são praticamente inexistentes, a compreensão de porque alguns grupos apresentam diferenciação até mesmo dentro da mesma bacia oceanográfica (AVISE et al., 2000) e outros que são filopátricos não apresentam diferenciação, não é muito clara. (FRIESEN et al., 1996; AUSTIN et al., 2000; DEARBORN et al., 2003; STEVEES et al., 2005b). Dessa forma, uma investigação acurada da estrutura genética espacial e temporal de espécies de ampla distribuição, envolvendo diferentes tipos de marcadores moleculares, contribuírão para elucidar a verdadeira história do grupo (PALUMBI \& BAKER, 1994)

A distribuição da variabilidade genética dentro e entre populações é de fundamental interesse para o conhecimento da origem das espécies e dos mecanismos que mantém a diversidade (KIDD \& FRIESEN, 1998). Nas últimas décadas grande parte desses estudos foram voltados para dados morfométricos e de marcadores mitocondriais (KIDD \& FRIESEN, 1998). Estudos de genealogias nucleares para populações naturais de organismo não modelos são escassos na literatura (GODINHO et al., 2006). A aplicação dessas genealogias pode prover uma nova visão da história 
evolutiva de muitas populações (AVISE, 2000; GODINHO et al., 2006). O contraste de informações entre os marcadores mitocondriais e nucleares nos revelam diferentes aspectos da história das populações devido às diferentes características entre esses marcadores. Estes contrastes serão muito valiosos quando empregados para investigar complexos padrões da diversidade genética (GODINHO et al., 2006).

O padrão de baixa variabilidade genética observado através de marcadores mitocondriais para Larus dominicanus levantou duas principais hipóteses para interpretá-los: baixa diversidade genética como resultado de eventos demográficos ou como resultado de eventos seletivos (varredura seletiva). O contraste entre a diversidade genética observada em múltiplos loci nucleares comparados com a diversidade observada pelos marcadores mitocondriais, permite inferir que o DNA mitocondrial dessa espécie tenha passado por um ou consecutivos eventos de varredura seletiva. Dessa forma, um estudo com uma amostragem mais ampla se fez necessário para que análises populacionais mais acurada pudessem ser conduzidas. Se as populações de Larus dominicanus passaram por algum evento de gargalo populacional ou recente colonização, esperamos encontrar sinais de expansão nos genes nucleares. Sinais de expansão ou estrutura podem não ter sido detectados em análises prévias devido ao pequeno tamanho amostral (CONGDON et al., 2000).

Assim, utilizando uma análise comparativa entre citocromo b do DNA mitocondrial e $\beta$-Fibrinogênio do genoma nuclear em $L$ dominicanus, buscamos avaliar a distribuição da variabilidade genética desse grupo ao longo da costa brasileira. A interpretação de como a variabiliade genética dessa espécie esta distribuída ao longo da costa é extremamente relevante para a criação de futuros planos de manejo. Já que essa é uma espécie generalista, que se alimenta de lixos produzidos por diversas atividades antrópicas e tem deslocado diversas outras espécies de aves marinhas de distribuição 
mais restrita de seus sítios reprodutivos. Além disso L. dominicanus vem sendo considerado como um potencial transportador de diversas enterobactérias prejudiciais ao homem.

\section{OBJETIVOS}

O presente trabalho tem como objetivo investigar o padrão de variabilidade genética de Larus dominicanus na costa Brasileira, através do uso de genealogia de gene nuclear, para responder as seguintes questões:

(1) Quanto de diversidade genética existe dentro e entre as populações de gaivotões?

(2) Qual é o fluxo gênico entre as localidade amostradas?

(3) há sinal de expansão populacional ou seleção nesse gene nuclear ou em alguma região da distribuição dessa espécie.

(4) O que podemos inferir da história evolutiva desse grupo e qual a sua consequência para a conservação e manejo da espécie na costa brasileira.

\section{METODOLOGIA}

Áreas amostradas

Para este trabalho foram amostrasdas duas localidades do litoral brasileiro (São Paulo $n$ = 20) (Santa Catarina $n=21)$, uma localidade da Península Antártica $(n=7)$, a ilha SubAntartica Marion $(n=3)$. Um fragmento de de 835bp intron 7 do gene $\beta$-Fibrinogênio foi sequenciados. O $\beta$-Fibrinogênio é um blood-borne glicoproteína, composta por três cadeias polipeptidicas não idênticas, envolvido no reparo de danos vasculares . Foi ulitizado como grupo externo em todas as análises sequências de Larus atricilla e Larus occidentalis provenientes do Genebank (AY695186, AY695185, respectivamente). 
As Reações de Cadeia de Polimerase (PCRs) foram feitas para um volume final de $10 \mathrm{ul}$ contendo (50mM Tris- $\mathrm{HCl}, 50 \mathrm{mM} \mathrm{NaCl}, \mathrm{pH} 8.5)$; 200uM dNTPs , $0.5 \mathrm{u}$ de Gotaq DNA polymerase (Promega), 5 pmol de cada primer e 2,5 $\mathrm{mM}$ de $\mathrm{MgCl}_{2}$ e aproximadamente 50ng de DNA. Os ciclos da PCR começam com desnaturação de 5 min a $95^{\circ} \mathrm{C}$, seguido de 38 ciclos de 30 s a $95^{\circ} \mathrm{C}, 45 \mathrm{~s}$ a $61^{\circ} \mathrm{C}, 1$ min a $72{ }^{\circ} \mathrm{C}$ e extensão final de 7 min a $72{ }^{\circ} \mathrm{C}$. Os produtos de PCR foram corridos em gel de Agarose 2\%, e as reações que apresentaram boas amplificações com bandas claras e únicas foram sequenciadas.

Os produtos das PCRs foram purificados através de EXO-SAP e sequenciados através BigDye 3.1 no sequenciador da ABI Prism ${ }^{\circledR} 3100$ DNA. As sequências foram editadas no ChromasLite 3.1 (Technelysion) e alinhadas no BioEdit (HALL, 1999). A definição dos haplótipos foi realizada através do programa PHASE (STEPHENS et al. 2001).

\section{Estimativas de variabilidade}

Medidas do polimorfismo do DNA foram calculadas considerando o modelo de finitos sítios. As seguintes medidas foram estimadas: número de haplótipos, diversidade haplotípica (probabilidade que dois haplotipos aleatorios escolhidos sejam diferentes em uma amostra), diversidade nucletotidica $(\pi)$ é a média da diversidade nucleotídica por sitio entre duas sequências; a estimativa de Theta (por sitio) $\theta=4 \mathrm{~N} \mu$, o Eta ( $\eta$ ) é o número total de mutações e o $\mathrm{S}$ é o número de segregantes sítios (sitos polimórficos). Todas essas medidas foram feitas através do programa DNAsp (ROZAS et al., 2003).

Para estimar se a variabilidade observada desvia da variabilidade esperada foram realizados os testes D de Tajima (TAJIMA, 1989) e Fu e Li (D* e F*) (FU \& LI, 1993) 
Foi calculado a distribuição da diferença nucleotídica par-a-par observada e os valores esperados em uma população em equilíbrio (Mismatch distribution). Foi também realizada a estimativa da estatistica de Reggedness " $r$ " e o intervalo de confiança para este valor foi computado por simulações usando algorítmo coalescente gerado no programa DNAsp.

A total variância molecular dentro e entre as regiões estudas de Larus dominicanus foi particionada pela Analise de variância Molecular (AMOVA) foi realizada pelo Arlequin ver 3.1 (EXCOFFIER et al., 1992) baseia-se na análise de variância das frequências gênicas, mas leva em conta o número de mutações entre os haplótipos moleculares. Dessa forma, o teste analisa hierarquicamente a repartição da variância dentro dos componentes de variação (variação inter-individual ou interpopulacional). Os Fst entre pares de população também foram estimados pelo programa Arlequim, para investigar as diferenças genéticas entre pares de populações, sendo seus valores de probabilidade gerados através da distribuição nula por 1000 permutações aleatórias. O número de migrantes entre pares de populações por geração foi calculado através da formula:

$$
\mathrm{Fst}=1 /(4 \mathrm{Nm}+1)
$$

As genealogias nucleares foram reconstruidas através de arvores de Neighbour joining através do programa MEGA 3.1 (KUMAR et al., 1993). E a robustez da árvore estimada por boostrap (FELSENSTEIN, 1985), com 10000 replicações. Esta árvore não representa a verdadeira genealogia, mas permite vizualizar os agrupamentos de alelos. Análises seguindo alternativas ligações incluindo múltiplas possíveis conexões foram realizadas pela construção de uma rede de haplótipos com reduzido median-joining com auxílio do programa networking 3.1 software (ROHL, 2000). O teste "four-gamete" e 
cálculos do número mínimo de recombinação (Rm ; HUDSON \& KAPLAN, 1988) foi realizado com o auxílio do programa DNASP 4.0 (ROZAS et al., 2003).

\section{RESULTADOS}

O fragmento de $\beta$-Fibrinogênio amplificado mostrou grande diversidade genética, com 42 haplótipos distintos, com 22 sítios polimórficos, diversidade haplotípica de 0,896 e a diversidadade nucleotídica $(\pi)$ de 0,0047 (Tabela XXXI). A estimativa de theta $(\theta=4 \mathrm{~N} \mu)$ para o intron $7 \quad \beta$-Fibrinogênio foi 0,005 por sítios $(\theta=$ 4,39 por gene).

Tabela XXXI.: Análises da diversidade genética do intron 7 do gene $\beta$-Fibrinogênio para as populações amostradas de Larus dominicanus, comparando o número de sítios polimórficos $(\mathrm{S})$, número de haplótipos $(\mathrm{NH})$, a diversidade haplotípica (h) e a diversidade nucleotídica $(\pi)$ e o Theta $(\theta)$ por gene.

\begin{tabular}{lcccccc}
\hline Localidade & $\mathrm{N}$ & $\mathrm{S}$ & $\mathrm{NH}$ & $\mathrm{H}$ & $\pi$ & $\Theta$ \\
\hline São Paulo & 40 & 15 & 23 & 0,956 & 0,0050 & 3,526 \\
Santa Catarina & 40 & 15 & 26 & 0,792 & 0,0040 & 3,526 \\
Antártica & 14 & 6 & 4 & 0,571 & 0,0023 & 1,887 \\
Marion & 6 & 0 & 0 & 0 & 0 & 0 \\
Todas localidades & 100 & 22 & 42 & 0,896 & 0,0047 & 4,39 \\
\hline
\end{tabular}

A distribuição da observada diferença nucleotídica par-a-par de haplótipos mostrou desvio significativo para o intron 7 do $\beta$-Fibrinogênio tanto quando consideramos a amostragem livre de recombinação quanto consideramos com a taxa de recombinação calculada no DNAsp $\mathrm{R}=10$. Já para o fragmento de $305 \mathrm{pb}$ do citocromo $\mathrm{b}$ não foi observado desvio significativo entre os valores observados e esperados de diferença par- a-par (Fig 24). Os testes de neutralidade (D de Tajima e Fu \& Li D* e F*) 
não apresentaram desvios significativos para as populações ou para todas as amostras em conjunto (Tabela XXXII). Com exceção do teste de Fu \&Li D* para a população de Santa Catarina que mostra um valor positivo e significativo para este teste, indicando haver estrutura no estado.
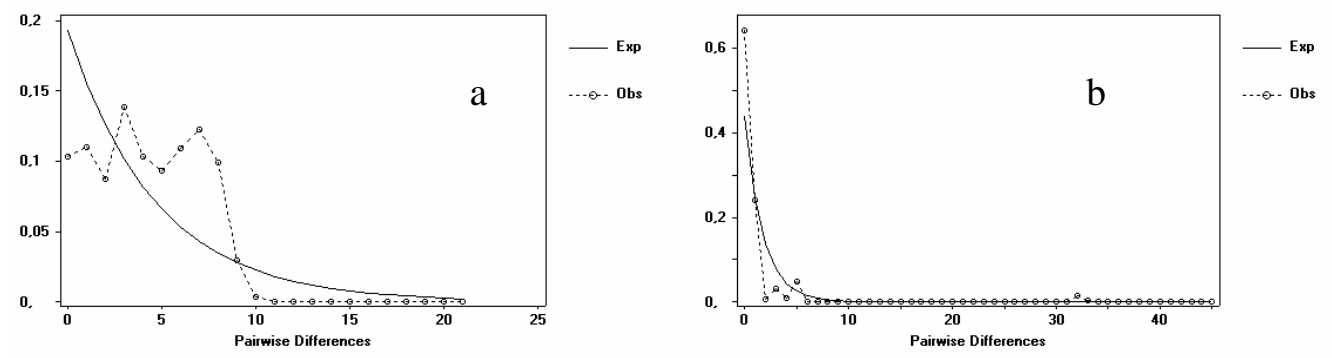

Figura 24.: Mismatch distribution para o (a) intron $7 \quad \beta$-Fibrinogênio de Larus dominicanus (sem recombinação $r=0,011 \mathrm{p}=0,008$; com recombinação de $\mathrm{R}=10 \mathrm{r}=0,011$ $\mathrm{p}=0,006)$ e (b) cyt B de Larus dominicanus $(\mathrm{r}=0,22 \mathrm{p}=0,66)$.

Tabela XXXII : Teste de neutralidade para o intron 7 do gene $\beta$-Fibrinogênio das populações de Larus dominicanus.

\begin{tabular}{c|ccc}
\hline Localidades & D deTajima & Fu e Li's D* & Fu e Li's F* \\
\hline São Paulo & $0,978 p>0,10$ & $1,079 p>0,10$ & $1,234 p>0,10$ \\
Santa Catarina & $-0,047 \mathrm{p}>0,10$ & $\mathbf{1 , 6 0 9} \mathbf{p}<\mathbf{0 , 0 2}$ & $1,249 \mathrm{p}>0,10$ \\
Antartica & $0,278 \mathrm{p}>0,10$ & $0,020 \mathrm{p}>0,10$ & $0,278 \mathrm{p}>0,10$ \\
\hline Total & $-0137 \mathrm{p}>010$ & $0,586 \mathrm{p}>0,10$ & $0,370 \mathrm{p}>0,10$ \\
\hline
\end{tabular}

A árvore filogenética mostra um grande compartilhamento de haplótipos entre as regiões e baixo suporte para os ramos com bootstraps abaixo de 50 (Fig 25). A rede de haplótipos apresenta-se muito entrelaçadas, com inúmeras possíveis ligações entre os haplótipos (Fig 26). O teste "four-gamete" demonstrou que o esse fragmento do beta fibrinogênio apresenta o número mínimo de recombinações igual a 12. 


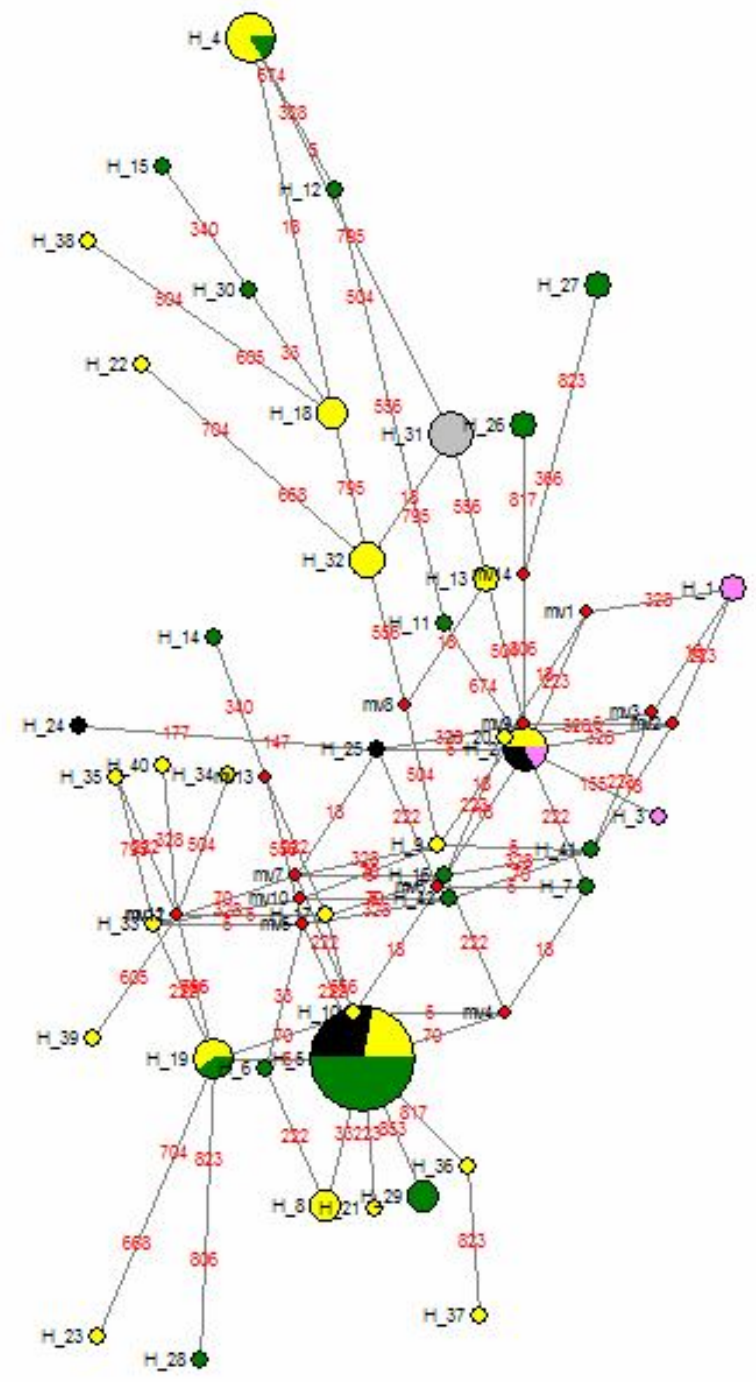

Figura 25.: Reduzido Median-joining network representando as relações filogenéticas entre os haplótipos do gene $\beta$-Fibrinogênio, o tamanho do círculo é proporcional a frequência de cada haplótipo na amostra total. A cor vermelha haplótipos antigos ou não amostrados, a cor verde representa indivíduos de Santa Catarina, amarelo de São Paulo, preto da Antártica e cinza corresponde ao grupo externo (Larus occidentalis e Larus attricilla). 


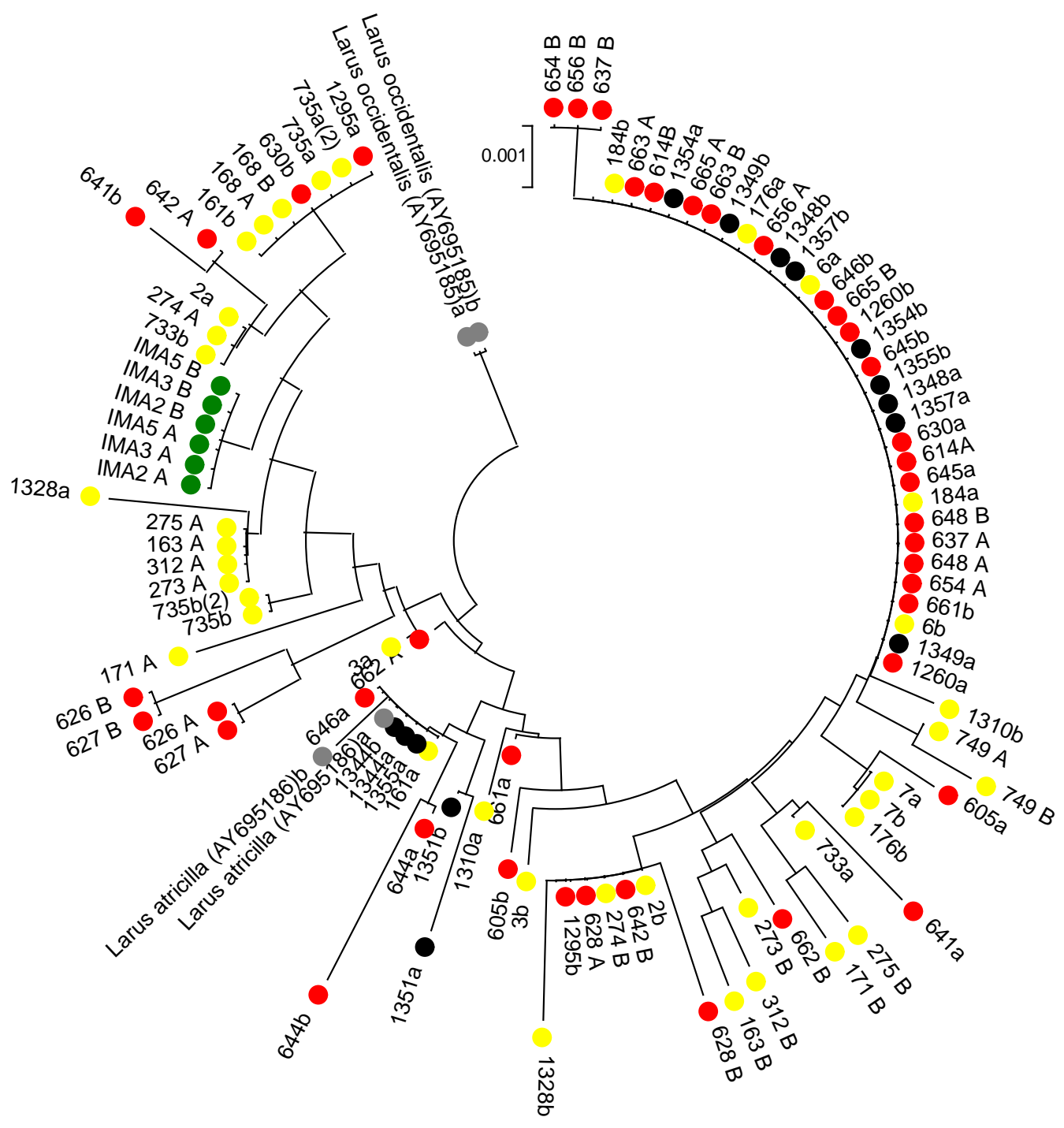

Figura 26: Árvore de Neighbourgh Joining para o intron 7 do gene $\beta$-Fibrinogênio, onde círculos vermelhos são amostras de Santa Catarina, amarelo amostras de São Paulo, preto amostras da Península Antártica, verde das Ilhas Marion e cinza amostras de grupo externo (Larus occidentalis e Larus attricilla).

A análise de variância molecular mostrou significativo índice de diferenciação entre as populações, porém grande parte da variação se encontra dentro das populações $(86,25 \%)$ (Tabela XXXIII). As estimativas de $\mathrm{F}_{\mathrm{ST}}$ por par de populações também revelou valores significativos de diferenciação entre as populações, sendo as Ilhas Marion a população mais deferenciada de Larus dominicanus, apresentando somente um único haplótipo. A população de São Paulo é significativamente diferente da 
população de Santa Catarina e da Península Antártica. Entretanto, a população de Santa

Catarina não foi significativamente diferente da Península Antártica (Tabela XXXIV).

Tabela XXXIII.: Análise de Variância Molecular (AMOVA) para o gene $\beta$ Fibrinogênio incluindo as três macro-regiões da distribuição de Larus dominicanus analisadas neste estudo.

\begin{tabular}{lcccc}
\hline Fontes de variação & d.f. & $\begin{array}{c}\text { Soma de } \\
\text { quadrado }\end{array}$ & $\begin{array}{c}\text { Componentes } \\
\text { de variação }\end{array}$ & $\begin{array}{c}\text { Porcentagem } \\
\text { de variação }\end{array}$ \\
\hline Entre populações & 3 & 5,369 & $0,06397 \mathrm{Va}$ & 13,75 \\
Dentro de populações & 96 & 38,531 & $0,40137 \mathrm{Vb}$ & 86,25 \\
\hline Total & 99 & 43,900 & 0,46534 & \\
\hline
\end{tabular}

Fst $=0,13748 p=0,000$

Tabela XXXIV.: Fst por par de regiões para o gene $\beta$-Fibrinogênio (Hemimatriz inferior) e estimativa de $\mathrm{Nm}$ (hemimatriz superior). Valores significativos $\operatorname{com} \mathrm{p}<0,05$ estão indicados em negrito. NG significa valores negativos.

\begin{tabular}{l|cccc}
\hline & São Paulo & Santa Catarina & Antártica & Ilhas Marion \\
\hline São Paulo & - & 8,907 & 1,679 & 0,454 \\
Santa Catariana & $\mathbf{0 , 0 2 7 3 0}$ & - & 5,407 & 0,369 \\
Antártica & $\mathbf{0 , 1 2 9 6 0}$ & 0,04419 & - & 0,136 \\
Ilhas Marion & $\mathbf{0 , 3 5 5 0 1}$ & $\mathbf{0 , 4 0 3 6 3}$ & $\mathbf{0 , 6 5 7 4 7}$ & - \\
\hline
\end{tabular}

O número de migrantes estimado pelo $\mathrm{F}_{\mathrm{ST}}$ por par de populações mostra valores altos dentro da costa brasileira e entre a Costa Brasileira de Península Antártica, mas revela um fluxo restrito entre Ilhas Marion e Costa Brasileira e Península Antártica (tabela XXXIV).

\section{DISCUSSÃO}

A diversidade genética observada no fragmento do intron $7 \beta$-Fibrinogênio de Larus dominicanus foi superior à diversidade encontrada para as análises com dois genes mitocondriais na mesma espécie. $\mathrm{O}$ fragmento desse intron mostra a diversidade haplotípica 4 vezes maior que a observada no DNA mitocondrial para o citocromo b e cerca de 10 vezes maior em relação à diversidade nucleotídica. DOLMAN e MORITZ (2007) ao compararem a divergência de múltiplos locus nucleares com resultados de 
locus mitocondriais para Carlia rubrigularis (lagartos) observaram que a diversidade média dos locus nucleares era duas vezes menor que a dos locus mitocondriais. Resultado oposto do que encontramos para Larus dominicanus para o locus analisado. A diversidade nucleotídica encontrada para as populações de Larus dominicanus estão um pouco acima do esperado para organismo eucariotas, no genoma nuclear de organismos eucariotas é geralmente pequeno não sendo maior que 1 a $2 \%$ em muitos casos (ZHANG \& HEWITT, 2003).

Para uma população em equilíbrio (deriva e mutação) é esperado que a distribuição das diferenças nucleotídicas par-a-par observadas seja multimodal, o que reflete a alta estocasticidade formada pela árvore gênica, mas a presença de um único pico gráfico (gráfico unimodal) indica que a população tenha passado por uma recente expansão populacional (EXCOFFIER et al., 1992). Nossas análises para o intron 7 do $\beta$-Fibrinogênio mostraram desvio signiticativo tanto quando consideramos a amostragem livre de recombinação quanto consideramos com a taxa de recombinação calculada no DNAsp R=10. Entretanto, no gráfico não notamos mais de um pico, o que indica que essa população não tenha passado por algum evento de recente expansão. Na análise do fragmento do citocromo b não foi observado desvio significativo entre os valores observados e esperados de diferença par-a-par, o que já era esperado devido à pequena diversidade encontrada nesse fragmento em Larus dominicanus (apenas um sítio polimórfico). A estatística de regardeness tem baixo poder estatístico para detectar expansão populacional. Dessa forma, os teste de D de Tajima e Fu \& $\mathrm{Li}\left(\mathrm{F}^{*}\right.$ e $\left.\mathrm{D}^{*}\right)$ foram conduzidos, mas também não mostraram significativos valores de expansão populacional. Assim podemos concluir que as populações de Larus dominicanus amostradas nesse trabalho estão sob evolução neutra, não apresentando desvios 
significativos entre a diversidade observada e a esperada sob o modelo neutro (KIMURA, 1968).

A árvore de Neighbour Joining para o intron 7 do $\beta$-Fibrinogênio apresentou bootstraps abaixo de $50 \%$ para praticamente todos os nós. O que reflete o grande número de haplótipos deferenciados por apenas um ponto mutacional. Esse padrão também pode ser observado na rede de haplótipos que se mostra um padrão reticulado. O grupo externo Larus atricilla apresenta o mesmo haplótipo encontrado tanto na costa brasileira como na Península Antártica, o que reflete a idéia que essa espécie apresentam divergência recente, seja o tempo desde a divergência insuficiente para a completa separação de linhagens através do DNA nuclear. Porém, a diversidade das populações não foi baixa e nenhuma população foi monifilétca.

A análise de variância molecular (AMOVA) mostrou significativa repartição da diversidade genética. Entretanto, grande parte da variação ainda se encontra dentro das populações amostradas. As ilhas Marion, apesar da pequena amostragem $(n=3)$ é a localidade que mais se diferencia, isso se deve à presença de um único e exclusivo haplótipo encontrado nessa região. Seguido por uma diferenciação sul/norte entre a Península Antártica e a costa do Estado de São Paulo. Na ausência de seleção uma taxa de migração de 0,5 por geração seria o suficiente para homogenizar as populações. As estimativas de fluxo gênico baseado no $\mathrm{F}_{\mathrm{ST}}$ mostraram que há um intenso fluxo entre as regiões amostradas o que corrobora os dados de baixa diferenciação observada nos loci nucleares e a não associação entre a relação dos haplótipos e suas distribuições geográficas.

A estimativa do número de migrantes baseado nos valores de Fst considera que as populações estão sob equilíbrio mutação deriva e que o número de migrantes é 
cosntante ao longo do tempo. Isso pode não ser uma estimativa real quando se trata de populações sujeitas a flutuações populacionais. 


\section{CONCLUSÃO GERAL}

Larus dominicanus é uma espécie de ampla distribuição no Hemisfério Sul que tem apresentando grande sucesso reprodutivo. O que implica em um potencial incremento populacional anual. Esse crescimento populacional tem sido observado por diversos pesquisadores em campo. Essa espécie tem levado ao deslocamento de outras aves e mamíferos marinhos, sendo motivo de preocupação para a conservação da avifauna marinha. Nossos resultados de razão sexual indica que suas populações ao longo da costa brasileira estão estáveis, com igual proporção entre machos e fêmeas. Estes resultados refletem as boas condições ambientais que essa espécie tem encontrado com a ocupação da costa e o crescente aumento das atividades antropicas nesse ecossistema.

Os dados genéticos encontrados nesse trabalho indicam que essa espécie é um bom modelo para a compreeensão dos processos evolutivos que têm atuado em aves marinhas. A falta de diferenciação genética no DNA mitocondrial encontrado nessa espécie ao longo de toda a sua distribuição no hemisfério sul e a grande diversidade genética no DNA nuclear nos leva a considerar diferentes hipóteses evolutivas para explicar esse padrão. Muitos trabalhos de genética população com aves marinhas têm encontrado baixa diversidade genética no DNA mitocondrial, justificando estes resultados muitas vezes pela alta vagilidade desses grupos. Ao mesmo tempo se observa a especiação de taxons próximos que ocorrem na mesma região geográfica e relativamente perto que apresentam os mesmo padrões comportamentais. A capacidade de voar em conjunto com a inexistência de barreiras físicas e geográficas para dispersão desse grupo faz com que essa seja a explicação mais aceita para as aves marinhas. Por

outro lado, quando nos deparamos com resultados de tão baixa diversidade como encontrado no DNA mitocondrial de Larus dominicanus o primeiro impulso é explicar 
esse padrão através de eventos demográficos, como gargalos populacionais ou recente colonização. Entretanto, quando ampliamos a amostragem dessa espécie não encontramos diferenciação genética, em conjunto com os dados dos marcadores nucleares que apresentam grande diversidade genética e ausência de indicíos de expansão populacional faz com que consideremos outras hipóteses como seleção no DNA mitocondrial. Estes resultados abrem uma nova perspectiva de análise que ainda precisam ser testadas, mas que podem justificar a especiação de alguns grupos e sua baixa diversidade dentro desse marcador mitocondrial.

Quanto a conservação e manejo dessa espécie nossas análises populacionais com base em dados nucleares não indicam que essa espécie tenha baixa diversidade genética a ponto de ser preocupante para a conservação. Nosso dados também indicam que as ilhas Marion são um grupo diferenciado em relação as populações encontradas na costa brasileria e Península Antártica; e ainda a Península Antártica parece ser um grupo difrenciado da costa brasileira. Estudos com outros marcadores, como microssatélites e SNPs, e uma ampla amostragem ao longa da distribuição dessa espécie, incluindo amostras da costa pacífica da América do Sul, da Austrália e das ilhas sub-Antárticas devem ser realizados para refinar a estrutura populacional desse grupo. 
ANEXO I

Lista dos primers testados para a amplificação de locus nucleares em Larus dominicanus, em negrito os primers utilizados com sucesso nesse trabalho.

\begin{tabular}{|c|c|c|c|c|c|c|}
\hline Gene & $\begin{array}{l}\text { Cromo } \\
\text { ssomo }\end{array}$ & intron & Primer F (5'-3') & Primer R $\left(5^{\prime}-3^{\prime}\right)$ & Gradiente & Autor \\
\hline ACL & 27 & 16 & GCTCTGCTTATGACAGCACT & CAGCAATAATGGCAATGGTG & $55^{\circ}$ a $65^{\circ}$ & $\begin{array}{l}\text { Primmer et al. } \\
2000\end{array}$ \\
\hline$\overline{\mathrm{AK} 1}$ & 17 & 4 e 5 & TGCAAGCCATCATGGAGAAGG & TGATGGTCTCCTCGTTGTCG & $55^{\circ}$ a $65^{\circ}$ & CIBIO \\
\hline \multirow[b]{2}{*}{ AVEN } & \multirow[b]{2}{*}{5} & 4 & GCTGCAGGAATTGCCTTAC & ACAGACTGGGAGACCAACG & $50^{\circ}$ a $60^{\circ}$ & Gisele Dantas \\
\hline & & 4 & GTTGACTGCCAGTCCTTGG & ACAGACTGGGAGACCAACG & $50^{\circ}$ a $60^{\circ}$ & Gisele Dantas \\
\hline \multirow{2}{*}{ AXIN } & \multirow{2}{*}{14} & 7 & GATCTCCTGAAGACGTGG & AAGGCTGGACGACGTTCC & $49^{\circ}$ a $60^{\circ}$ & Gisele Dantas \\
\hline & & 7 & GATCTCCTGAAGACGTGG & ATGGGACAGCTGCTTCTTAGC & $49^{\circ}$ a $60^{\circ}$ & Gisele Dantas \\
\hline CEPU & 24 & 1 & CGAGTCAAAGTCACCGTCAA & CTCTTCGCATCCGAGATGTA & $55^{\circ}$ a $65^{\circ}$ & $\begin{array}{l}\text { Primmer et al. } \\
2000\end{array}$ \\
\hline CPITSLREO1 & & & GCTACCGCAGGGAGGACT & CGGTGTCTCCGTTTCTCT & $50^{\circ}$ a $65^{\circ}$ & $\mathrm{CIBIO}$ \\
\hline CRYBB1 & 15 & & GCGCAGTGTCATCGTCAG & ATCTCCCCACGCATGTTG & $50^{\circ}$ a $65^{\circ}$ & CIBIO \\
\hline CWNT-8C & 13 & 3 & AGTGCAAGTTCCAGTTCG & CTAAGCTGCAGTTCCTGG & $47^{\circ}$ a $57^{\circ}$ & Gisele Dantas \\
\hline FIB & 4 & 7 & CAGGACAATGACAATTCAC & GTAGTATCTGCCATTAGG & $55^{\circ}$ a $65^{\circ}$ & $\begin{array}{l}\text { (adapted from } \\
\text { Prychitko and } \\
\text { Moore, 1997) }\end{array}$ \\
\hline
\end{tabular}




\begin{tabular}{|c|c|c|c|c|c|c|}
\hline GAL & 3 & 1 & ATGAAGATCCTGTACCTGC & TCCCAATAGCTATGTGTGG & $47^{\circ} \mathrm{a} 57^{\circ}$ & Gisele Dantas \\
\hline \multirow{2}{*}{ GAPDH } & \multirow{2}{*}{1} & 2 & CACTATAAAGGCGAGATGG & CACCATGTAGTTCAGATCG & $55^{\circ} \mathrm{a} 65^{\circ}$ & CIBIO \\
\hline & & 2 & GCAGGTACACTATAAG & CACCATGTAGTTCAGATCG & $55^{\circ} \mathrm{a} 65^{\circ}$ & CIBIO \\
\hline \multirow{2}{*}{ L3 } & \multirow{2}{*}{11} & 3 & CGACTGTCAGATACCACA & GAGCGATACTCCTTCAGC & $48^{\circ} \mathrm{a} 58^{\circ}$ & Gisele Dantas \\
\hline & & 3 & CGACTGTCAGATACCACA & CCTTTCTTCGGTGCAGAC & $48^{\circ}$ a $58^{\circ}$ & Gisele Dantas \\
\hline LEP100 & 1 & & GATCACCTTCCACTTTGT & TGTCATTCGATGCTTCAA & $55^{\circ} \mathrm{a} 70^{\circ}$ & CIBIO \\
\hline LPL & Z & 3 & TGTCTGCTGCTTACACGAAGC & AGCAATCCCAGCAGCATGAGC & $55^{\circ} \mathrm{a} 65^{\circ}$ & CIBIO \\
\hline LRPP40 & 2 & 5 & GGGCCTGATGTGGTGGATGCTGGC & GCTTTCTCAGCAGCAGCCTGCTC & $55^{\circ} \mathrm{a} 65^{\circ}$ & $\begin{array}{l}\text { Primmer et al. } \\
2000\end{array}$ \\
\hline MPLPR & UNK & 4 & TACATCTACTTTAАСАСCTGGACCACCTG & TTGCAGATGGAGAGCAGGTGGGAGCC & $55^{\circ} \mathrm{a} 70^{\circ}$ & $\begin{array}{l}\text { Primmer et al. } \\
2000\end{array}$ \\
\hline MYO & & & & & $50^{\circ} \mathrm{a} 65^{\circ}$ & CIBIO \\
\hline ODC & 3 & $6 \mathrm{e} 7$ & GACTCCAAAGCAGTTTGTCGTCTCAGTGT & ATATTAGCTGGTCTTTGGTAAGTTAC & $50^{\circ} \mathrm{a} 70^{\circ}$ & CIBIO \\
\hline $\mathrm{OV}$ & 2 & $3 \mathrm{e} 4$ & ATTCGGAGACAGATATGAAGC & GAAATGTGATAGGTTCCAAGC & $52^{\circ} \mathrm{a} 65^{\circ}$ & CIBIO \\
\hline PAX3 & 9 & 2 & ACATACCAGCTCTCTGAGC & TGCTTTGGTGTACAGTGC & $48^{\circ} \mathrm{a} 62^{\circ}$ & Gisele Dantas \\
\hline RAG1 & 5 & 1 & СCTCCTGCTGGTATCCCTGC & GAATGTTCTCAGGATGCGTCC & $55^{\circ} \mathrm{a} 65^{\circ}$ & $\begin{array}{l}\text { (adaptado de } \\
\text { Groth e } \\
\text { Barrowclough, } \\
\text { 1999) }\end{array}$ \\
\hline RDPS & UNK & 1 & TGCTACATCGAGGGCTTGTT & CGAGTGACCAGAGAGCGATT & $55^{\circ} \mathrm{a} 65^{\circ}$ & $\begin{array}{l}\text { Primmer et al. } \\
2000\end{array}$ \\
\hline RGS4 & 8 & 2 & CTGCAGAAGTCAGAATCC & AGTTTTCCAGCGACTCTGC & $48^{\circ}$ a $58^{\circ}$ & Gisele Dantas \\
\hline & & 3 & TCGCTGGAAAACTTGATCC & GTAGTCCTCACAACTGACC & $48^{\circ} \mathrm{a} 62^{\circ}$ & Gisele Dantas \\
\hline
\end{tabular}




\begin{tabular}{|c|c|c|c|c|c|c|}
\hline RPL7A & 17 & 7 & GGCTGTCAAGACCAACTA & TTGGACCCAAGACATTAC & $50^{\circ}$ a $65^{\circ}$ & CIBIO \\
\hline SEF & 12 & 5 & TACTTTGTCAAGATTGTGC & GAGGTTTTCTGGCTGTAGC & $42^{\circ}$ a $55^{\circ}$ & Gisele Dantas \\
\hline UBL & 7 & 2 & GTGAAATTCACTTCAAGG & CTCGAAGAGAAACCCGAG & $42^{\circ}$ a $55^{\circ}$ & Gisele Dantas \\
\hline VIM & 2 & 7 & TGCTTCTTTGAACCTGAGAG & GTGTCCTCTTCGAGTGAGTG & $50^{\circ}$ a $65^{\circ}$ & $\begin{array}{l}\text { Smith et al. } \\
1997\end{array}$ \\
\hline
\end{tabular}




\section{BIBLIOGRAFIA}

\section{Introdução Geral}

Bertellotti M \& Yorio P (1999) Spatial and temporal patterns in the diet of kelp Gull in Patagonia. Condor 101: 790-798.

Frankhan R, Ballou JD \& Briscoe DA (2002) Introduction to conservation genetics. Cambridge UK, Cambridge University Press, 617p.

Giccardi M, Yorio P \& Luzurume ME (1997) Patrones estacionales de abundancia de la gaivotas (Larus dominicanus) em un basural patagonico y sus relaciones con el manejo de residuos urbanos e pesqueros. Ornitologia Neotropical 77-84

Gill, F.B. (1994). Ornithology. WH Freeman and Company, New York, USA.

Harrison P (1985) Seabirds: Identification Guide. Houghton Miflin.

Hunter ML (1996) Fundamentals of Conservation Biology. Blackwell Science, Massachusetts.

Moritz C (2002) Strategies to Protected biological diversity and the evolutionary processes that sustain it. Systematics Biological 51. 238-254.

Primack RB \& Rodrigues E (2001) Biologia da Conseração. Midiograf, Londrina, Paraná.

Quintana F \& Yorio P (1998) Competition for nest sites between kelp Gull (Larus dominicanus) and Terns (Sterna maxima and S. eurygnatha) in Patagonia. Auk 115: 1068-1071.

Rosário LA (1996) As aves de Santa Catarina: distribuição geográfica e meio ambiente. Florianopolis, SC.

Rowntree V J, MacGuinness P, Marshall K, Payne R, Sirone M \& Seger J. (1998) Increased harassment of Right Whales (Eubalena australis) by Kelp Gull (Larus dominicanus) at Peninsula Váldez, Argentina. Marine Mammal Science 14 (1): 99- 115.

Rozzi R, Primack R, Feinsinger P, Dirzo R \& Massardo F (1998) qué es la biología de la conservación? Pg 35-58 In: Primack R, Rozzi R, Feinsinger P, Dirzo R \& Massardo F. Fundamentos de Conservación Biológica: Perspectivas latinoamericans. Fondo de cultura Económica México.

Sick H (1997) Ornitologia Brasileira. Nova Fronteira, Rio de Janeiro, Brasil. 
Vidal E, Roche P, Bonnet V \& Tatoni T (2001) Nest-density distribuition patterns in Yellow-legged gull archipelogo colony. Acta Oecology 22. 429-436.

Yorio P, Bertelloti M, Gandini P \& Frere E (1998) Kelp Gulls Larus dominicanus breeding in the Argentina Coast: Population Status and relationship with coastal management and conservation. Marine Ornithology 26: 11-18.

\section{Capitulo I}

Anderson DJ \& Hodum PJ (1993) Predator behaviour favors clumped nesting in an oceanic seabirds. Ecology 74: 2462-2464.

Bertellotti M \& Yorio P (1999) Spatial and temporal patterns in the diet of kelp Gull in Patagonia. Condor 101: 790-798.

Borboroglu PG \& Yorio P (2004) Habitat requirements and selection by Kelp Gull (Larus dominicanus) in central and northern Patagonia, Argentina. Auk 121: 243-252.

Campos F P, Paludo D, Faria PJ \& Martuscelli P (2004) Aves Insulares, Residentes ou Migratórias das ilhas costeiras do Estado de São Paulo. In: Branco JO (ed) Aves Marinhas e Insulares Brasileiras; bioecologia e conservação. Univali, Itajaí

Doherty PF \& Grubb TC (2002) Survivorship of permanent resident birds in a fragmented forested landscape. Ecology 83: 844-857.

Fraser W R (1989) Aspects of the ecology of kelp Gull (Larus dominicanus) on Anvers island, Antartic Peninsula. PhD thesis, university Minnesota, Minneapolis.

Gill FB (1994). Ornithology. WH Freeman and Company, New York, USA.

Good-Thomas 2002

Guicking D, Mickstein S, Becker PH \& Schalatter R (2001) Nest site selection by Brown-hooded Gull (Larus maculipennis), Trudeaus Tern (Sterna tredeaui) and White-faced Ibis (Plegadis chili) in south Chilean tule marsh. Ornitologia Neotropical 12: 285-296.

Herbert PN \& Barclay RN (1988) Parental investment in Herring Gull: clutch apportionment and chick survival. Condor 90:332-338.

Hoyt DF (1979) Practical Methods of estimating volume and fresh weight of birds eggs. AUK 96: 73-77 
Kladec JA \& Drury WH (1968) Structure of the New England Hering Gull population. Ecology 49: 644-676

Meathrel CE \& Ryder JP (1987) Intraclutch variation in the size, mass and composition of Ring- Billed Gull eggs. Condor 89: 364-368.

Oro D \& Pradell R (2000) Determinants of local recruitment in a growing colony of Audouin's gull. Journal of Animal Ecology 69: 119- 132.

Oro D (1996) Colonial seabird nesting in dens and small sub-colonies: an advantage against aerial predation. Condor 98: 848-850.

Paynter RA Jr (1949) Clutch size and egg and chick mortality of kent Island Herring Gull. Ecology 30: 146-166.

Pianka E (1999) Evolutionary Ecology.Addison Wesley Educational, San Francisco, USA.

Rodway MS \& Regehr HM (1999) Habitat selection and reproductive performance of food-stressed Herring gull. Condor 101: 566-576

Rosário LA (1996) As aves de Santa Catarina: distribuição geográfica e meio ambiente. Florianopolis, SC.

Saliva JE \& Burguer J (1989) Effects of experimental manipulation of vegetation density on nest site selection in sooty terns. Condor 91: 689-698.

Salzman AG (1982). The selective importance of heat sress in Gull net location. Ecology 63: 742- 751.

Sampaio IBM (2002) Estatística Aplicada à experimentação Animal. UFMG. Belo Horizonte.

Sick H (1997) Ornitologia Brasileira. Nova Fronteira, Rio de Janeiro, Brasil.

Skorka P, Wójcik JD \& Nartyka R (2005) Colonization Growth of Yellow legged Gull Larus cachinnans in Southeastern Poland: causes and influence on native species. Ibis 147: 471- 482.

Soares M \& Fonseca Schiefler A (1995) Reprodução de Larus dominicanus (Aves, Laridae), na Ilhota Galheta, Laguna, SC, Brasil, Arquivos de Biologia e Tecnologia 38, 313-316.

Vidal E, Roche P, Bonnet V \& Tatoni T (2001) Nest-density distribuition patterns in Yellow-legged gull archipelogo colony. Acta Oecology 22. 429-436.

Yorio P \& Borboroglu PG (2002) Breeding Biology of kelp Gull (Larus dominicanus) at Golfo San Jorge, Patagonia, Argentina. Emu 102:257-263 
Yorio P , Boersma PD \& Swan, S (1996) Breeding Biology of the Dolphin Gull at Punta Tombo, Argentina. Condor 98: 208-215.

Yorio P, Bertellotti M \& Quintana F (1995) Preference for covered nest sites and breeding success in Kelp Gull (Larus dominicanus). Marine Ornithology 23: $121-128$

\section{Capitulo II}

Ayres M, Ayres M Jr, Ayres DL \& Santos AS (1998) BioEstat: Aplicações Estatísticas nas áreas das Ciências Biológicas e Médicas. Sociedade Civil de Mamirauá, MCT, CNPq, Manaus, Brasil.

Clutton-Brock TH (1985) Sex ratio variation in birds. Ibis 128: 317-329.

del Hoyo, J., Elliott, A., and J. Sargatal. 1996. Handbook of the Birds of the World. Vol. 3. Hoatzin to Auks. Lynx Edicions. Barcelona.

Dijkstra C, Daan S, Pen I (1998) Fledgling sex ratio in relation to brood size in sizedimorphic altricial birds. Behaviral Ecology 9: 287-296.

Fisher RA (1973) The genetical theory of natural selection. Claredon, Oxford.

Frankhan R, Ballou JD \& Briscoe DA (2002) Introduction to conservation genetics. Cambridge UK, Cambridge University Press, 617p.

Fridolfsson AK, Cheng H, Copele NG, Jekins NA, Liu HC, Woodage T, Chowdhary B, Halverson J \& Ellegren H (1998) Evolution of the avian sex chromosomes from na ancestral pair autosomes. Genetics 95: 9147-9152

Griffths R, Double MC, Orr K \& Dawson R (1998) A DNA test to sex most birds. Molecular Ecology 7: 1071-1075.

Hoyt DF (1979) Practical Methods of estimating volume and fresh weight of birds eggs. AUK 96: 73-77

Nager RG, Monaghan P, Houston DC \& Genovart M (2000) Parental condition, brood sex ratio and differential young survival and experimental study in gulls (Larus fuscus). Behavirol Ecology Sociobiologival 51: 238-254.

Pianka E (1999) Evolutionary Ecology.Addison Wesley Educational, San Francisco, USA.

Quintana F \& Yorio P (1998) Competition for nest sites between kelp Gull (Larus dominicanus) and Terns (Sterna maxima and S. eurygnatha) in Patagonia. Auk 115: $1068-1071$. 
Sheldon BC (1998) Recent Studies of avian sex ratio. Heredity 80: 397- 402.

Torres R \& Drummond H (1997) Female-biased mortality in nesting of a bird woth size dimorphism. Journal Animal Ecology 66: 859-865.

Trivers RL \& Willard DA (1973) Natural Selection of parental ability to vary the sex ratio of offspring. Science 179: 859-865.

Vedder O, Dekker AL, Visser GH \& Dijkstra C (2005) Sex-specific energy requirements in nestlings of an extremely sexually size dimorphic bird, the European sparrowhawk (Accipiter nisus). Behaviral Ecology Sociobiology 58: 429-436.

Yorio P, Bertelloti M, Gandini P \& Frere E (1998) Kelp Gulls Larus dominicanus breeding in the Argentina Coast: Population Status and relationship with coastal management and conservation. Marine Ornithology 26: 11-18.

\section{Capitulo III}

Akey JM, Eberle MA, Rieder MJ, Carlson CS, Shriver MD, Nickerson DA \& Kruglyak L (2004) Population History and natural selection shape patterns of genetic variation in 132 genes. PLOS Biology 2 (10): 1591-1599.

Austin JJ, Whoite RWG \& Ovenden JR (1994) Population-genetic structure of phylopatric colonially nesting seabirds, the Short-tailed Shearwater (Puffinus tenuirostris). AUK 11:70-79

Avise JC, Nelson WS, Bowen BW \& Walker D (2000) Phylogeography of colonially nesting seabirds, with special reference to global matrilineal patterns in the Sooty tern (Sterna fuscata). Molecular Ecology 9: 1783-1892

Ballard J WO \& Whtlock MC (2004). The incomplete natural history of mitochondria. Molecular Ecology 13: 729-744.

Begon M, Harper JL \& Towsend CR (1996) Ecology: Individuals, Populations and Communities. Blackwell, Boston, USA

Bigarela JJ (1965) Subsidios para estudos da variação do nível oceânico no Quatenário brasileiro. Annais da Academia Brasileira de Ciências 37: 263-278.

Bridge ES, Jones AW \& Baker A (2005) A phylogenetic framework for terns (Sterninii) inferred from DNAmt sequences: implications for taxonomy and plumage evolution. Molecluar Phylogenetics and Evolution in press 
Brown LM, Ramey II RR, Tamburini B \& Gavin TA (2004) Population structure and mitochondrial DNA variation in sedentary Neotropical birds isolated by forest fragmentation. Conservation Genetics 5: 743-755.

Burguer TM \& Croxall JP (2001) Global relationship amongst black-bowed and greyheaded albatrosses: analysis of population structure using mitochondrial DNA and micorssatellites. Molecular Ecology 10:2647-2660.

Congdon BC, Piatt HF, Martin K \& Friesen VL (2000) Mechanisms of population differentiation in Marbled Murrelets: Historical versus contemporary processes. Evolution 54 (3): 974-986.

Crochet PA \& Desmarais E (2000) Slow rate of evolution in the mitochondrial Control Region of Gulls (Aves: Laridae). Mol. Biol. Evol 17 : 1797-1806.

Crochet PA, Lebreton JD \& Bonhomme F (2002) Systematics of Large white-headed gulls: patterns of mitochondrial DNA variation in western European taxa. Auk 119: 603-620.

Excoffier L, Smouse PE \& Quattro JM (1992) Analysis of molecular variance inferred from metric distances among DNA haplotypes: application to human mitochondrial DNA restriction data. Genetics 131: 479-491.

Frankhan R, Ballou JD \& Briscoe DA (2002) Introduction to conservation genetics. Cambridge UK, Cambridge University Press, 617p.

Friesen VL, Piatt JF \& Baker AJ (1996) Evidence from Cytochrome b sequences and allozymes for a "new" species of alcid: The long-billed murreler (Brachyramphus peridix). Condor 98: 681-690.

Galtier N, Depaulis F \& Barton NH (2000). Detecting Bottlenecks and Selective sweep from DNA Sequence polymorphism. Genetics 155: 981-987.

Genovart ML, Oro D \& Bonhomme F (2003) Genetic and Morphological differentiation between two largest breeding colonies of Audouin's Gull Larus audouinii. Ibis 145: 448-456.

Hall T A (1999) BioEdit: a user-friendly biological sequence alignment editor and analysis program for Windows 95/98/NT. Nucl. Acids. Symp. Ser. 41:95-98.

Hartl DL \& Clarck AG (1989) Principles of Population genetics. In Sinaurer Massachusetts, USA, $682 \mathrm{p}$.

Helbig AJ \& Seibold J (1999) Molecular Phylogeny of Paleartic- Affrican Acrocephalus and Hippolis Warblers (Aves: Sylviidae). Molecular Phylogenetics and Evolution 11: 246-260. 
Hey J \& Machado CA (2003) The study of structured populations-new hope for a difficult and divided science. Nature Rewies 4: 535-543.

Kidd MG \& Friesen VL (1998) Analysis of mechanisms of microevolutionary change in Cepphus guillemots using patterns of control region variation. Evolution 52: 1158-1168.

Liebers D, Helbig AJ \& kniff PDe (2001) Genetic differentiation and phylogeography of gulls in the Larus cachinnans-fuscus group (Aves: Charadriiformes). Molecular Ecology 10: 2447-2462.

Liebers D, kniff PDe \& Helbig AJ (2004) The Herring Gull complex is not a ring species. Proc. R. Soc. Lond B 271: 893-901.

MacCauley DE (1991) Genetics consequences of local Population Extinction and recolonization. Tree 6: 5-8.

Mindell DP, Sorenson MD \& Dimcheff DE (1998) Multiple independent origins of mitochondrial gene order in birds. Proc. Natl. Acad. Sci. USA 95: 1069310697.

Moritz C (2002) Strategies to Protected biological diversity and the evolutionary processes that sustain it. Systematics Biological 51. 238-254.

Oro D \& Pradell R (2000) Determinants of local recruitment in a growing colony of Audouin's gull. Journal of Animal Ecology 69: 119- 132.

Pons, JM, Crochet PA, Thery M \& Bermejo A (2004) Geographical variation in the Yellow-legged gull: introgression or convergence from the Herring Gull? J.Zool.Syst. Research 42: 245-256.

Quintana F \& Yorio P (1998) Competition for nest sites between kelp Gull (Larus dominicanus) and Terns (Sterna maxima and S. eurygnatha) in Patagonia. Auk 115: 1068-1071.

Rohl A (2000) Network: Phylogenetic Network Analysis, v.3.1.1.1 Fluxus Technology, Ltd.

Rozas J, Sanchés-DelBarrio JC, Messeguer X \& Rozas R (2003) DnaSP, DNA polymorphism analyses by the coalescent and other methods. Bioinformatics 19: $172-175$.

Sambrook KJ, Russel DW \& Sambrook J (2001) Molecular Cloning: a laboratory Mannual.CSHL, New York, USA.

Slatkin M (1987) Gene flow and geography structure of natural population.Science 236. 787-792. 
Sorenson MD (2003) Avian mtDNA primers. Página pessoal 1-3

Steeves TE, Anderson DJ \& Friesen VL (2005a) The Isthmus of Panama: a major physical barrier to gene flow in a highly mobile pantropical seabirds. Journal Evolution Biology 18: 1000-1008

Steeves TE, Anderson DJ \& Friesen VL (2005b) A role for nonphysical barriers to gene flow in the diversification of highly vagile seabird, the masked booby (Sula dactylatra) Molecular Ecology 14: 3877-3887.

Suguio K (2004) O papel das variações do nível relativo do mar durante o Quateernario tardio na origem da baixada litoranea da Jureia, SP. In: Otavio AV, Marques, Wania Duleba (eds) Estação ecológica Juréia-Itatins: ambiente físico, flora e fauna. Holos, Ribeirão Preto, SP, pp 33-41.

Tarr CL \& Fleischer RC (1999) Population boundaries and genetic diversity in endagered Mariana crow (Corvus kubaryi). Molecular Ecology 8: 941-949

Underhell LG. Avian demographic Unit. Department of Statistical Sciences, university Cape Town, 2002, Eletronic Citation

Zink RM, Lott DF \& Anderson DW (1987) Genetic variation, population structure and evolution of Caifornia Quail. Condor 89: 395-405.

\section{Capitulo IV}

Austin JJ, Whoite RWG \& Ovenden JR (1994) Population-genetic structure of phylopatric colonially nesting seabirds, the Short-tailed Shearwater (Puffinus tenuirostris). AUK 11:70-79

Avise JC, Nelson WS, Bowen BW \& Walker D (2000) Phylogeography of colonially nesting seabirds, with special reference to global matrilineal patterns in the Sooty tern (Sterna fuscata). Molecular Ecology 9: 1783-1892

Ballard J WO \& Whtlock MC (2004). The incomplete natural history of mitochondria. Molecular Ecology 13: 729-744.

Berrebi P, Retif X, Fang F \& Zhang CG (2006) Population Structure and systematics of Opsariichthys bidens (Osteichthyes:Cyprinidae) in south-eat China using a new nuclear marker:the introns (EPIC-PCR). Biological Journal of the Linnean Society 87: 155-166.

Burguer TM \& Croxall JP (2001) Global relationship amongst black-bowed and greyheaded albatrosses: analysis of population structure using mitochondrial DNA and micorssatellites. Molecular Ecology 10:2647-2660. 
Crochet PA, Lebreton JD \& Bonhomme F (2002) Systematics of Large white-headed gulls: patterns of mitochondrial DNA variation in western European taxa. Auk 119: 603-620.

Dantas GPM, Velosa AR, Campos FP, Olinto JB \& Morgante JS (2006) Genetic variability and sex ratio in the Kelp Gull: Implications for management and conservation of seabirds", Journal of Ornithology 147 (5): 230-231.

Dolman G \& Moritz C (2006) A multilocus perspective on refugial isolation and divergence in rainforest skinks (Carlia). Evolution 60:573-582.

Dolman G \& Phillips B (2004) Single copy nuclear DNA markers characterized for comparative phylogeography $\mathrm{n}$ Australian Wet tropics rainforest skinks. Molecular Ecology Notes 4: 185-187.

Excoffier L, Smouse PE \& Quattro JM (1992) Analysis of molecular variance inferred from metric distances among DNA haplotypes: application to human mitochondrial DNA restriction data. Genetics 131: 479-491.

Fu Y-X \& Li WH (1993) Statistical tests of neutrality of mutations. Genetics 133: 693-709.

Hall T A (1999) BioEdit: a user-friendly biological sequence alignment editor and analysis program for Windows 95/98/NT. Nucl. Acids. Symp. Ser. 41:95-98.

Kimura M (1968) Evolutionary rate at the molecular level. Nature 217: 624-626.

Kumar S, Tamura K \& Nei M (1993). MEGA: Molecular evolutionary genetics analysis. Vers 3.1 Pennsylvania State Univ., University Park, PA.

Luikart G \& Cornut JM (1998) Empirical evaluation of test for identifying recently bottleneck population from allele frequency data. Conservation Biology 12:228-237.

Moore WS (1995) Inferring phylogenies from mtDNA variation: mithocondrial-gene tree versus nuclear-gene trees. Evolution 49: 718- 726.

Nei M \& Kumar S (2000) Molecular evolution and Phylogenetics.Oxford University Press.New York, USA.

Nei M (1987) Molecular evolutionary genetics. Columbia University Press, New York, NY, USA.

Palumbi SR \& Baker CS (1994) Constrasting population structure from nuclear intron sequences and mtDNA of Humpbak Whales. Mol. Biol. Evol. 11:426-435.

Palumbi SR, Cipriano F \& Hare M (2001) Predicting nuclear gene coalescence from mitochondrial data: the three-times rule. Evolution 55: 859-868. 
Pasb申ll PJ, Berube M, Aguilar A, Di-Sciara GN \& Nielsen R (2004) Discerning between recurrent gene flow and recent divergence under a finite-site mutation model applied to north Atlantic and Mediterranean sea fin whale (Balaenoptera physalus) populations. Evolution 58 (3) 670-675.

Pons, JM, Crochet PA, Thery M \& Bermejo A (2004) Geographical variation in the Yellow-legged gull: introgression or convergence from the Herring Gull? J.Zool.Syst. Research 42: 245-256.

Primmer CR, Borge T, Lindell J \& Saetre GP (2002) Single-nucleotide polymorphism characterization in species with limited avaiable sequence information: high nucleotide diversity revealed in the avian genome. Molecular Ecology 11: 603-612.

Rohl A (2000) Network: Phylogenetic Network Analysis, v.3.1.1.1 Fluxus Technology, Ltd.

Rozas J, Sanchés-DelBarrio JC, Messeguer X \& Rozas R (2003) DnaSP, DNA polymorphism analyses by the coalescent and other methods. Bioinformatics 19: $172-175$.

Slatkin M \& Hudson RR (1991) Pairwise comparisons of mitochondrial DNA sequences in stable and exponentially growing population. Genetics 129:555562.

Slatkin M \& Maddison WP (1990) Detecting isolation by distance using phylogenies of genes. Genetics 126: 249-260.

Stephens M, Smith NJ \& Donnelly P (2001) A New Statistical Method for Haplotype reconstruction from Population data. Am J Hum. Genet. 68:978-989.

Tajima F (1989) Statistical method for testing the neutral mutation hypothesis by DNA polymorphism. Genetics 123:585-595.

Zhang X \& Hewitt GM (2003) Nuclear DNA analyses in genetic studies of populations: practice, problems and prospects. Molecular Ecology 12: 563-584.

\section{Capitulo V}

Austin JJ, Whoite RWG \& Ovenden JR (1994) Population-genetic structure of phylopatric colonially nesting seabirds, the Short-tailed Shearwater (Puffinus tenuirostris). AUK 11:70-79 
Avise JC, Nelson WS, Bowen BW \& Walker D (2000) Phylogeography of colonially nesting seabirds, with special reference to global matrilineal patterns in the Sooty tern (Sterna fuscata). Molecular Ecology 9: 1783-1892

Congdon BC, Piatt HF, Martin K \& Friesen VL (2000) Mechanisms of population differentiation in Marbled Murrelets: Historical versus contemporary processes. Evolution 54 (3): 974-986.

Dearborn DC, Anders AD, Schreiber EAS, Adams MM \& Mueller UG (2003) Interisland movements and population differentiation in a pelagic seabird. Molecular ecology 12: 2835-2843.

Dolman G \& Moritz C (2006) A multilocus perspective on refugial isolation and divergence in rainforest skinks (Carlia). Evolution 60:573-582.

Excoffier L, Smouse PE \& Quattro JM (1992) Analysis of molecular variance inferred from metric distances among DNA haplotypes: application to human mitochondrial DNA restriction data. Genetics 131: 479-491.

Friesen VL, Piatt JF \& Baker AJ (1996) Evidence from Cytochrome b sequences and allozymes for a "new" species of alcid: The long-billed murreler (Brachyramphus peridix). Condor 98: 681-690.

Fu Y-X \& Li WH (1993) Statistical tests of neutrality of mutations. Genetics 133: 693-709.

Godinho R, Mendonça B, Crespo EG \& Ferrand N (2006) Genealogy of the nuclear $\beta$-Fibrinogen locus in a highly structured lizard species: comparasion with mtDNA and evidence for intragenic recombination in the hybrid zone. Heredity 96: 454-463.

Hall T A (1999) BioEdit: a user-friendly biological sequence alignment editor and analysis program for Windows 95/98/NT. Nucl. Acids. Symp. Ser. 41:95-98.

Hudson RR \& Kaplan NL (1985). Statistical properties of the number of recombination events in the history of a sample of DNA sequences. Genetics 111: $147-164$.

Kidd MG \& Friesen VL (1998) Analysis of mechanisms of microevolutionary change in Cepphus guillemots using patterns of control region variation. Evolution 52: 1158-1168.

Kimura M (1968) Evolutionary rate at the molecular level. Nature 217: 624-626.

Kumar S, Tamura K \& Nei M (1993). MEGA: Molecular evolutionary genetics analysis. Vers 3.1 Pennsylvania State Univ., University Park, PA. 
Palumbi SR \& Baker CS (1994) Constrasting population structure from nuclear intron sequences and mtDNA of Humpbak Whales. Mol. Biol. Evol. 11:426-435.

Rohl A (2000) Network: Phylogenetic Network Analysis, v.3.1.1.1 Fluxus Technology, Ltd.

Rozas J, Sanchés-DelBarrio JC, Messeguer X \& Rozas R (2003) DnaSP, DNA polymorphism analyses by the coalescent and other methods. Bioinformatics 19: $172-175$.

Steeves TE, Anderson DJ \& Friesen VL (2005b) A role for nonphysical barriers to gene flow in the diversification of highly vagile seabird, the masked booby (Sula dactylatra) Molecular Ecology 14: 3877-3887.

Tajima F (1989) Statistical method for testing the neutral mutation hypothesis by DNA polymorphism. Genetics 123:585-595.

Zhang X \& Hewitt GM (2003) Nuclear DNA analyses in genetic studies of populations: practice, problems and prospects. Molecular Ecology 12: 563-584. 